\title{
STAN I ODBUDOWA SIECI KOŚCIELNEJ W LACIŃSKIEJ DIECEZJI KIJOWSKIEJ W DRUGIEJ POLOWIE XVII I W XVIII WIEKU
}

Niniejszy artykuł stanowi próbę omówienia rozwoju sieci katolickich kościołów (parafialnych, zakonnych, filialnych) oraz kaplic publicznych obrządku łacińskiego na terenie diecezji kijowskiej w okresie od połowy XVII do końca XVIII wieku. Była to epoka poważnych zniszczeń, a następnie stopniowej odbudowy struktur terytorialnych Kościoła. Zniszczenia rozpoczęły się powstaniem Chmielnickiego w 1648 roku i trwały z przerwami do drugiej dekady XVIII stulecia. Podjęto wtedy akcję przywracania dawnych struktur, a następnie zakładania nowych ośrodków kościelnych. W literaturze nie został dotychczas w sposób pełny i wyczerpujący omówiony proces rozwoju łacińskiej sieci parafialnej na ziemiach ruskich dawnej Rzeczypospolitej, a do wielu istniejących prac zgłaszano cały szereg zastrzeżeń. Należy stwierdzić, że nadal istnieje wiele luk w posiadanej przez nas wiedzy dotyczącej omawianego zagadnienia $i$ wydaje się konieczne podjęcie prac nad ich wypełnieniem ${ }^{1}$.

Cały obszar diecezji kijowskiej (najogólniej rzecz biorąc odpowiadający w XVII wieku zasięgowi województw kijowskiego i czernihowskiego) został objęty powstaniem kozackim w 1648 roku, a potem przez blisko 60 lat był terenem prawie nieustannych walk. Powstanie, w którym początkowo siły kozackie i tatarskie walczyły przeciwko wojskom polsko-litewskim przerodziło się w wojnę domową, a następnie stało się przyczyną wybuchu wojny Rzeczypospolitej z Moskwą. Kościół katolicki (w tym także jego struktury terenowe) był jednym z głównych celów ataków ze strony Kozaków, Tatarów i Moskali. Było jasne, że odbu-

\footnotetext{
* Jacek Chachaj - dr historii, adiunkt w Instytucie Historii Wydziału Nauk Humanistycznych KUL

${ }^{1}$ Zarys rozwoju łacińskiej sieci kościelnej na terenie diecezji kijowskiej do 1648 roku autor przedstawił w artykule Rozwój sieci światyń katolickich obrządku łacińskiego na terenie diecezji kijowskiej do połowy XVII wieku, w: Ecclesia-Cultura-Potestas. Studia z dziejów kultury i społeczeństwa. Księga poświęcona s. prof. U. Borkowskiej OSU, red. P. Kras, A. Januszek, A. Nalewajek, W. Polak, Kraków 2006, s. 85-104, gdzie omówiono także stan literatury i podstawę źródłową.
} 
dowa struktur terenowych Kościoła katolickiego będzie możliwa tylko na obszarach, które znajdą się ostatecznie pod kontrolą sił polskich, będących jedyną katolicką stroną walk. Wojska polskie w 1660 roku odzyskały panowanie nad prawobrzeżną Ukrainą, zaś na przełomie 1663 i 1664 roku podjęły działania na lewym brzegu Dniepru. Skutkiem niepowodzenia tych działań był rozejm andruszowski zawarty między Polską a Moskwą w 1667 roku, który oddał, jak się potem okazało na zawsze, wschodnią część Ukrainy pod panowanie carów. Przekreślało to ostatecznie jakiekolwiek możliwości odbudowy struktur Kościoła katolickiego na tym obszarze. Z kolei w wyniku najazdu tureckiego z 1672 roku Polska straciła także południową część prawobrzeżnej Ukrainy (formalnie odzyskała te obszary w 1699 roku). Aż do drugiej dekady XVIII wieku w wyniku kolejnych walk władza polska nad Kijowszczyzną lub jej poszczególnymi częściami miała często charakter jedynie nominalny. Dopiero po 1711 roku nastąpiło trwałe przywrócenie realnych polskich rządów, a co za tym idzie pojawiły się dogodne warunki do odbudowy struktur terytorialnych Kościoła katolickiego obrządku łacińskiego ${ }^{2}$. Musimy jednak pamiętać, że długoletni okres zniszczeń doprowadził na Ukrainie do znacznego wyludnienia, a na niektórych terenach nawet zerwania ciągłości osadniczej ${ }^{3}$. Właściwie dopiero wraz z przywróceniem władzy polskiej na prawobrzeżnej Ukrainie zostały ustalone na nowo granice diecezji kijowskiej, które przetrwały aż do upadku Rzeczypospolitej. Przy czym jeszcze w końcu XVIII wieku nie były one precyzyjnie określone. Diecezja obejmowała w tym czasie województwo kijowskie, część należącego do Litwy powiatu mozyrskiego (gdzie leżały Babicze stanowiące dobra stołowe biskupów kijowskich) oraz położoną nad górną Rosią część województwa bracławskiego (z którym województwo kijowskie nie miało stałego rozgraniczenia). Na północy diecezja kijowska sąsiadowała $\mathrm{z}$ diecezją wileńską, a granicę ,z wyjątkiem pewnych miejsc" stanowiła Prypeć. Na zachodzie i południowym zachodzie $\mathrm{z}$ diecezją łucką, przy czym granicę z województwem wołyńskim stanowiła rzeka Słucz, zaś z województwem bracławskim rzeka Roś „wyjąwszy przez używanie pewne miejsca”. Na stosunkowo najkrótszym odcinku diecezja kijowska graniczyła także na południowym zachodzie z diecezją kamieniecką, a granica przebiegała Czarnym Szlakiem. Brak precyzyjnych i stałych granic prowadził do sporów między plebanami sąsiednich diecezji i zdawano sobie sprawę z konieczności ostatecznego uregulowania tej kwestii. Jednocześnie przechowywano wtedy pamięć o tym, że diecezja przed

${ }^{2}$ W nowszej literaturze dzieje ziem ukrainnych Rzeczypospolitej w okresie 1648-1710 z różnych punktów widzenia przedstawiają w sposób ogólny: W. A. Serczyk, Historia Ukrainy, wyd. 2, Wrocław-Warszawa-Kraków 1990, s. 117-179; N. Jakowenko, Historia Ukrainy. Od czasów najdawniejszych do końca XVIII wieku, Lublin 2000, s. 219-275; J. A. Gierowski, Rzeczpospolita w dobie złotej wolności (1648-1763), Kraków 2001, s. 20-49, 81-87, 95-103, 118-121, 125-128, 135 143, 152, 167-171, 233-235, 252-253, 270-271.

${ }^{3} \mathrm{Na}$ Ukrainie miały miejsce ,zhiny”, czyli przymusowe przesiedlenia ludności (przegony) na lewy brzeg Dniepru. Najdokładniej omówiono w nowej literaturze załamanie się osadnictwa na Podolu w czasie panowania tureckiego. Zob.: D. Kołodziejczyk, Podole pod panowaniem tureckim. Ejalet kamieniecki 1672-1699, Warszawa 1999. Podobne zjawiska dotyczyły zapewne także południowej części prawobrzeżnej Ukrainy, która także znalazła się pod przejściowym władztwem Porty. 
okresem zniszczeń obejmowała całe województwo kijowskie, czernihowskie oraz „,inne księstwa kijowskie"4.

Powstanie Chmielnickiego, a następnie pochody wojsk kozackich i moskiewskich w głąb Rzeczypospolitej uniemożliwiły funkcjonowanie struktur administracyjnych diecezji kijowskiej. Nie wiemy na jaką skalę próbowano przywracać je w latach sześćdziesiątych XVII wieku, choć istnieją ślady takiej działalności. Akcja ta załamała się w latach siedemdziesiątych, gdy wybuchły długotrwałe walki polsko-tureckie. Dopiero w 1684 roku biskup Chryzostom Załuski doprowadził do zebrania się kapituły katedralnej kijowskiej w kościele dominikanów w Lublinie i odzyskał prawo wysyłania przez nią deputata na Trybunał Koronny. Kapituła kijowska zbierała się w Lublinie aż do 1724 roku, gdy została przeniesiona do nowej katedry powstałej w Zytomierzus. W trzecim dziesięcioleciu XVIII wieku proces odbudowy struktur katolickiej diecezji kijowskiej obrządku łacińskiego był już bez wątpienia zaawansowany. Trudno jednak udzielić dokładnej odpowiedzi na pytanie o liczbę świątyń łacińskich funkcjonujących ówcześnie na jej terytorium.

Dotychczasowy stan wiedzy na temat rozwoju sieci kościelnej na terenie łacińskiej diecezji kijowskiej w XVIII wieku nie przedstawia się imponująco. W zasadzie sprowadza się on do ogólnych liczb świątyń istniejących w różnych przekrojach czasowych. Na podstawie wiadomości zawartych w kilku opracowaniach poruszających interesujący nas problem za moment rozpoczynający odbudowę sieci kościelnej po okresie zniszczeń należy uznać rok 1723. Istnieje pogląd, że gdy biskup Samuel Ożga przybył wówczas do swej diecezji nie zastał w niej ani kościołów, ani kapłanów ${ }^{6}$. Starsza literatura zawiera wiadomość, że w początkach XVIII wieku istniało na obszarze diecezji siedem kościołów? jednak na ile wiarygodny jest ten przekaz, a także jakiego dokładnie momentu dotyczy. Wiele wskazuje na to, że momentem tym mogło być właśnie przybycie biskupa Ożgi na teren diecezji w 1723 roku$^{8}$. Po 25 latach, w 1748 roku na obsza-

${ }^{4}$ Michał Pałucki, Stan dyecezyi y katedry kijowskiej w roku 1782 opisany, Archiwum Kapituły Metropolitalnej Krakowskiej, Wawel, bez sygn., „w spuściźnie” F. A. Symona (dalej: Pałucki, Stan), k. 16. Bardzo ważne prace dotyczące granic diecezji polskich w okresie przedrozbiorowym wyszły spod pióra Bolesława Kumora. Zob. B. Kumor, Granice metropolii (halickiej) lwowskiej w okresie przedrozbiorowym, „Prawo Kanoniczne”, 11 (1968), z. 1-2, s. 3-20; tenże, Granice metropolii i diecezji polskich (968-1939), ABMK, 18 (1969), s. 285-352, 19 (1969), s. 271-351, 20 (1970), s. 253-374, 21 (1970), s. 309-404, 22 (1971), s. 319-402, 23 (1971), s. 361-399.

${ }^{5}$ Potem jeszcze w latach 1736-1743 kapituła zbierała się w kościele bernardynów w Sokalu, a w okresie konfederacji barskiej w kościele karmelitów w Berdyczowie. Pałucki, Stan, k. 13, 15.

${ }^{6}$ T. Długosz, Z dziejów biskupstwa kijowskiego, Lwów 1932, s. 18.

${ }^{7}$ Encyklopedja kościelna, wyd. M. Nowodworski, t. 10, Warszawa 1877, s. 331.

${ }^{8}$ Karol Orłowski opisując działalność biskupa Samuela Ożgi wspomniał zarówno o sprowadzeniu przez niego w 1724 roku kapituły kijowskiej z Lublina do Żytomierza, jak też o wizytacji, którą przeprowadził on w tym samym roku. Spośród kościołów wizytowanych wówczas wymienił wyraźnie tylko świątynię w Chwastowie. W innym miejscu wspomniał o wyposażaniu lub obdarowywaniu przez biskupa sprzętem kościelnym świątyń w czasie wizytacji. Tej informacji jednak Orłowski nie datował. Możemy tylko przypuszczać, że dotyczy ona okresu około 1723-1724 roku. Zwraca uwagę fakt, że wymienionych kościołów jest właśnie siedem. Defensa Biskupstwa y Dyecezyi 
rze diecezji kijowskiej istniało 19-20 kościołów (w tym co najmniej 14 parafialnych) ${ }^{9}$, około 1772 roku było 31 parafii ${ }^{10}$, w 1781 roku było ich $33^{11}$, a w 1793 roku $-43^{12}$

Kiiowskiey rzetelnym opisaniem z przydatkami niektóremi dla niey potrzebnemi światu remonstrowana Iaśnie Wielmożnemu Nayprzewielebnieyszemu Imci Xiędzu Samuelowi Ianowi z Ossy Ożdze Kijowskiemu y Czerniechowskiemu Biskupowi fundatorwi y osobliwszemu dobrodzieiowi w protekcya oddana przez Wielmożnego Imc Xiędza Karola Nepomucena Orłowskiego Arhidiakona [!] Katedralnego Kiiowskiego, Proboszcza Sędziszowskiego y Koniuskiego, Roku 1748, we Lwowie w drukarni SSS. Tróycy, Biblioteka Uniwersytecka KUL, Sekcja Starych Druków, sygn. XVIII 1616, s. 109, 111, 163. Jednocześnie należy pamiętać o tym, że nie mamy w tym przypadku do czynienia z typowymi aktami wizytacyjnymi, lecz jedynie zapewne z przypadkowymi wzmiankami. Wśród wymienionych świątyń zabrakło na pewno funkcjonujących w latach dwudziestych XVIII wieku kościołów jezuickich w Owruczu i Jurewiczach. Ich pominięcie mogło być związane z faktem, że nie były to kościoły parafialne. Podsumowując stwierdzamy, że liczba siedmiu świątyń działających w diecezji kijowskiej w początkach XVIII wieku może być zwykłą spekulacją któregoś z autorów opartą o jedną z możliwych interpretacji zapisów źródłowych.

${ }^{9}$ Długosz, Z dziejów, s. 18 (gdzie podano liczbę 20 parafii); Relacja o stanie diecezji kijowskiej biskupa Kaspra Kazimierza Cieciszowskiego z roku 1793, oprac. i wyd. B. Kumor, - ABMK 62 (1993), s. 150 (gdzie podano liczbę 14 parafii). Relacja biskupa Kajetana Sołtyka z 1751 roku odnotowała na terenie diecezji 21 kościołów, w tym 12 zakonnych (Długosz, $Z$ dziejów, s. 18). Nie wiemy jednak jak wiadomość tę odnieść do liczby 20 parafii, bowiem nie każdy kościół musiał pełnić funkcji świątyni parafialnej. Z kolei dane wizytacji z w lat 1746-1748 (Defensa Biskupstwa, s. 136$149 v$; E. Heleniusz [E. Iwanowski], Wspomnienia czasów dawnych i późniejszych, t. 1, Lwów 1894, s. 267-273, 297) pozwalają na stwierdzenie, że w rzeczywistości działało wtedy 19 kościołów (17 z nich realnie pełniło funkcje świątyń parafialnych) oraz kaplica w Pawołoczy ze stałym kapelanem, która także posiadała podległy sobie obszar. Jednocześnie praca K. Orłowskiego zawiera wiadomość o tym, że w Trojanowie i Narodyczach fundowano kościoły, ale parafie były dopiero w fazie organizacji. Może zatem Pawołocz, Trojanów i Narodycze zostały uwzględnione przez Długosza wśród 20 parafii, które istniały w 1748 roku.

${ }^{10}$ S. Litak, Kościót taciński w Rzeczypospolitej około 1772 roku. Struktury administracyjne, Lublin 1996, s. 42, tabela 2, s. 371-372. Autor wymienił 31 kościołów parafialnych, katedrę oraz pięć kościołów filialnych i kaplic (w sumie 36 świątyń). Inną liczbę podał T. Długosz ( $Z$ dziejów, s. 18), który stwierdził, że w 1773 roku biskup Franciszek Ossoliński zastał 27 parafii).

${ }^{11}$ Długosz, $Z$ dziejów, s. 18. Spośród 33 parafii 10 było prowadzonych przez zakony. Ponadto na obszarze diecezji istniały kościoły zakonne bez praw parafialnych. Spisany w 1782 roku Stan, k. 16v-19 na liście świątyń wymienił ich w sumie 48 . W tej grupie było 35 kościołów parafialnych (niektóre jeszcze bez uposażenia), 12 kościołów zakonnych, filialnych lub kaplic publicznych oraz 1 kościół zniszczony. Istniał wtedy także jeszcze jeden kościół (w Cudnowie) o czym świadczy wiadomość w innym miejscu (Stan, k. 19v).

${ }^{12}$ Relacja o stanie, s. 150, 153, 154; Długosz, Z dziejów, s. 18. Biskup Cieciszowski w swej relacji podał liczbę 43 parafii, w tym 14 zakonnych, oraz czterech klasztorów bez parafii i ośmiu oratoriów prywatnych. Warto wspomnieć o apelu biskupa Cieciszowskiego dotyczącym wykorzystania dóbr państwowych jako podstawy materialnej dla fundacji nowych parafii łacińskich (w związku z przechodzeniem łacinników na obrządek wschodni powodowanym brakiem świątyń). Sejm Czteroletni w odpowiedzi na ten apel uchwalił założenie na koszt Rzeczypospolitej 24 kolejnych parafii w królewszczyznach województw kijowskiego i bracławskiego w miejscach wskazanych przez biskupa. Każda parafia miała otrzymać jako uposażenie ziemię oraz 3 tysiące złotych rocznie (Encyklopedja kościelna, t. 10, s. 332; Długosz, Z dziejów, s. 21-22; Relacja o stanie, 
Punktem wyjścia naszych rozważań jest stan sieci kościelnej diecezji kijowskiej w pierwszych dziesięcioleciach XVIII wieku. Próbując go odtworzyć opieramy się przede wszystkim na podanej przez Karola Orłowskiego liście miejscowości posiadających kościoły w czasie wizytacji przeprowadzonej w latach czterdziestych XVIII wieku z polecenia biskupa Samuela Ożgi ${ }^{13}$. W końcu XIX wieku podobną (i w zasadzie zbieżną z danymi Orłowskiego) listę opublikował Eustachy Iwanowski ${ }^{14}$. Wymienił on miejscowości posiadające świątynie przed zniszczeniami z drugiej połowy XVII wieku podając także informację, czy kościoły lub kaplice funkcjonowały w tych miejscowościach w czasie wizytacji z lat czterdziestych XVIII wieku (co jest niewątpliwym śladem zależności zestawienia Iwanowskiego od danych Orłowskiego).

Natomiast w odtworzeniu stanu sieci kościelnej diecezji kijowskiej w pierwszej połowie XVIII wieku nie może być pomocna lista kościołów istniejących przed 1648 rokiem, z zaznaczeniem miejscowości, w których w wyniku wojen kościoły uległy zniszczeniu i nie zostały odbudowane, oraz tych, które znalazły się w składzie diecezji łuckiej, przedstawiona w 1782 roku przez Michała Pałuckiego. W rękopisie podkreślono nazwy parafii utraconych przez diecezję kijowską ${ }^{15}$, co oznacza, że miejscowości nie podkreślone posiadały świątynie w jej ramach. Nic nie wskazuje jednak na to, że lista odnosi się do stanu z pierwszej połowy XVIII wieku. Pałucki starał się w miarę możliwości podawać dane dotyczące dziejów diecezji kijowskiej, lecz miał zapewne duże problemy z dostępem do źródeł. Sam wyraźnie sugerował, że opisał stan diecezji ,ile można się było dowiedzieć”, bo wszystko musiał zbierać z fragmentów po spaleniu akt przez Moskali w Żytomierzu w 1768 roku $^{16}$. Choć bez wątpienia znał pracę Karola Orłowskiego z 1748 roku $^{17}$, w miejscu, gdzie opisywał stan diecezji przed zniszczeniami oparł się na odnalezionym przez siebie odpisie listu z 1715 roku, zawierającym spis świątyń z XVII wieku ${ }^{18}$. Wiedział, że nie jest to spis kompletny, ale być może

s. 150). Postanowień tych nie udało się zrealizować, ale nie jest wykluczone, że w niektórych miejscach podjęto przygotowania do założenia parafii, co mogło przynieść skutki w następnych latach.

${ }^{13}$ Defensa Biskupstwa, s. 136-149v. Nie znamy dokładnej daty wizytacji, w wyniku której sporządzono listę miejscowości posiadających świątynie. Została ona opublikowana w 1748 roku, lecz dekret biskupa związany z wizytacją jest datowany na 1746 rok (Tamże, s. 118). Opis Michała Pałuckiego zawiera wzmianki o pracy K. Orlowskiego, lecz wspomina także jako źródło „wizytę generalną Łaszczowską" (Pałucki, Stan, k. 1). Z bardzo dużym prawdopodobieństwem możemy przyjąć, że wspomnianą wizytacje powinniśmy łączyć z osobą biskupa antypatryńskiego Józefa Antoniego Łaszcza, który był koadjutorem biskupa Samuela Ożgi i zmarł w 1748 roku (Pałucki, Stan, k. 9-9v). Zatem albo musimy przyjąć, że praca Orłowskiego została oparta o wyniki wizytacji generalnej przeprowadzonej przez biskupa Łaszcza i opisuje stan opisany w czasie jej przeprowadzenia, albo powinniśmy uznać, że wizytacja biskupa Łaszcza została przeprowadzona wcześniej, lecz wtedy powinniśmy ją uznać za źródło zaginione.

${ }^{14}$ Heleniusz [Iwanowski], Wspomnienia, s. 266-267, 296-297.

${ }^{15}$ Pałucki, Stan, k. 15v-16.

${ }^{16}$ Pałucki, Stan, k. 21v.

${ }^{17}$ Pałucki, Stan, k. 1, gdzie cytuje Orłowskiego.

${ }^{18}$ Pałucki, Stan, k. 15v. Autor napisał, że podaje listę kościołów istniejących przed powstaniem Chmielnickiego ,wywnioskowaną z ekscerptu listu, który napisał ks. Stanisław Leriński (?), misjo- 
kierował się tym, że był najstarszy spośród tych, którymi dysponował. Na tym spisie (nieco krótszym od listy Orłowskiego, ale zawierającym ten sam siedemnastowieczny podział dekanalny) zapewne samodzielnie podkreślił kościoły, których ,albo ich teraz nie ma albo są w diecezji łuckiej” ${ }^{\prime 19}$. W sumie zatem lista Pałuckiego przedstawia sytuację z 1782 roku.

Podsumowując stwierdzamy, że najstarsze źródło przekrojowe dotyczące stanu osiemnastowiecznej sieci kościelnej łacińskiej diecezji kijowskiej, jakim dysponujemy, dotyczy lat 1746-1748. Na terenie diecezji istniało wówczas 20 kościołów, dwa kolejne były fundowane, ale jeszcze nie funkcjonowały, a uzupełnieniem sieci świątyń były dwie kaplice. Odbudowa wspomnianych przeszło 20 obiektów sakralnych stanowiła pierwszy etap podnoszenia diecezji kijowskiej $\mathrm{z}$ upadku spowodowanego zniszczeniami wojennymi. Wizytacja $\mathrm{z}$ lat 1746-1748 została przeprowadzona na obszarze, na którym istniało 100 lat wcześniej 40 parafii. Spośród nich aż $24(60 \%)$ nadal było zniszczonych lub nie należało już do diecezji kijowskiej. Poza 18 świątyniami odbudowanymi w 16 dawnych centrach parafii (w Żytomierzu i Owruczu istniały po dwa kościoły) odnotowano także dwie parafie w nowych ośrodkach (przy czym kościół w Czarnobylu istniał niewątpliwie przed 1648 rokiem, choć nie został umieszczony w spisach parafii z XVII wieku), misję jezuicką w Jurewiczach oraz dwie parafie w stadium organizacji. Wizytacja z 1746-48 roku notuje inną niż w 1648 roku strukturę dekanalną. Nie wiemy czy decyzja o zmianie struktury dekanalnej była efektem wizytacji, czy dokonano jej już wcześniej. W każdym razie została ona zapewne dostosowana do ówczesnego stanu sieci kościelnej. W 1748 roku na terenie diecezji kijowskiej istniały trzy dekanaty. Dekanat żytomierski obejmował parafie Żytomierz, Berdyczów, Białopole, Cudnów, Korosteszów i Lubar (oraz Trojanów w fazie organizacji); dekanat chwastowski: Chwastów, Biała Cerkiew, Byszów, Chodorków i Pawołocz, a także kaplicę jezuitów w Łuczynie; dekanat owrucki: Owrucz, Babicze, Chabno, Czarnobyl, Jurewicze, Olewsk, Ostrohładowicze i Wieledniki (oraz Narodycze $\mathrm{w}$ fazie organizacji) ${ }^{20}$. Na początek powinniśmy zatem przeanalizować wiadomości mówiące o odbudowie tej grupy świątyń.

Następny przekrojowy stan sieci kościelnej na omawianym obszarze możemy uzyskać analizując treść Statutów synodalnych diecezji kijowskiej opublikowanych przez biskupa Józefa Andrzeja Załuskiego w latach 1764-1767²1. Zawierają

narz jezuicki, 2 marca 1715 roku z Cudnowa do pewnego prałata kijowskiego, wpisanego w 1723 roku do akt kapitulnych".

${ }^{19}$ Pałucki, Stan, k. 16. Pałucki popełnił zresztą w tym miejscu błąd pisząc: „Tych 15 kościołów, które są podkreślone" (Tamże, k. 16), gdy tymczasem w tekście jest podkreślony nie 15 lecz 16 nazw miejscowości.

${ }^{20}$ Defensa Biskupstwa, s. 136-149v; Heleniusz [Iwanowski], Wspomnienia, s. 267-272.

${ }^{21}$ Statua synodalia dioecesis orthodoxae Kijoviensis publicata ab Illustrissimo Reverendessimo et Excellentissimo Domino D. Josepho Andrea Comite in Załuskie Junosza Załuski Episcopo Kijoviense \& Cerniechoviense, Regni Poloniae Senatore, Solij Pontificij Assistente, Equite Aquilae Albae, Abbate Wanchocensi in Polonia \& Villariae Betnaci in Lotharingia (ac Conciliario Praelato Honoris in Parliamento Nancejano) nec non Fontaneti in Burgundia, ac Conciliario in Parliamento Divionensi, Praeposito Insignis Ecclesiae Regiae Varsaviensis, Canonico Seniore Ecclesiae Cathe- 
one spis kościołów parafialnych wraz $\mathrm{z}$ ich okręgami parafialnymi ${ }^{22}$. Poddając jednak ten spis analizie stwierdzamy, że jest on w rzeczywistości przepisanym (jedynie z minimalnymi poprawkami) spisem K. Orłowskiego z 1748 roku. Stawia to pod znakiem zapytania jego wartość jako podstawy do odtworzenia sieci kościelnej diecezji kijowskiej w latach sześćdziesiątych XVIII wieku. Zdawano sobie zapewne sprawę z niewielkiej wartości spisu opublikowanego w Statutach, skoro w 1767 roku sporządzono kolejny spis kościołów parafialnych i dołączono go wraz z innymi informacjami do tej samej księgi ${ }^{23}$. Lista spisana w 1767 roku obejmuje 30 kościołów parafialnych (wśród których nie została wymieniona katedra żytomierska) i jedną kaplicę. Stanowi ona cenne źródło pozwalające stwierdzić na ile rozwinęła się sieć kościelna diecezji kijowskiej w czasie blisko 20 lat od czasu sporządzenia listy K. Orłowskiego. Jednocześnie musimy pamiętać, że ukazuje ona strukturę terytorialną Kościoła łacińskiego w przededniu kolejnej fali zniszczeń związanych w buntem, który wybuchł w 1768 roku.

Ostatnim źródłem przekrojowym ukazującym stan sieci kościelnej na interesującym nas obszarze jest wspomniany już opis diecezji kijowskiej sporządzony przez oficjała generalnego Michała Pałuckiego w 1782 roku$^{24}$. Jest to bez wątpienia podstawowe źródło dla badań nad rozwojem sieci kościelnej diecezji kijowskiej w XVIII wieku. Inne źródła mają mniejsze znaczenie i stanowią w zasadzie jedynie uzupełnienie dzieła M. Pałuckiego ${ }^{25}$. Dysponując dość dokładną wiedzą na temat stanu sieci kościelnej w 1782 roku możemy podjąć zarówno próbę przedstawienia jej rozwoju w okresie od lat 1746-1748 do sporządzenia Stanu dyecezyi, jak też w czasach przypadających na ostatnie dwudziestolecie XVIII wieku.

\section{STAN I ODBUDOWA SIECI KOŚCIELNEJ DO 1748 ROKU}

Powstanie Chmielnickiego przyniosło katastrofalne skutki dla struktur terytorialnych Kościoła łacińskiego na terenie diecezji kijowskiej. Zniszczenie musiały być bardzo duże, lecz nikt nie zdawał sobie zapewne sprawy, że okażą się one także zniszczeniami trwałymi. Wcześniej niejednokrotnie zdarzało się już, że diecezje położone na terenach ruskich ponosiły w wyniku obcych najazdów wielkie straty w sieci kościelnej ${ }^{26}$. Straty te były jednak stosunkowo szybko usuwane w wyniku odbudowy zniszczonych świątyń, co następowało po ustąpieniu na-

dralis Cracoviensis Membro Academiae Scientiarum ac Literariae Berolinensis, Petroburgensis, Romanae Infacundorum, Bononiensis, Florentinae, Lipsiensis, nancejanae, jenensis, Grypswaldensis \&c, Culmae in Prussia MDCCLXIV, Biblioteka Uniwersytecka KUL, Sekcja Rękopisów, sygn. XVIII 3636. Mimo podanej w księdze daty jej wydania w 1764 roku powinniśmy przyjąć, że została ona opublikowana nie wcześniej niż w 1767 roku. Wskazuje na to fakt, że z tego roku pochodzą uzupełnienia umieszczone na ostatnich stronach księgi.

${ }^{22}$ Tamże, s. 514-526.

${ }^{23}$ Tamże, s. bez numeracji [679-681].

${ }^{24}$ Pałucki, Stan .

${ }^{25}$ Litak, Kościół łaciński, s. 25.

${ }^{26} \mathrm{Na}$ przykład w wyniku najazdu turecko-tatarskiego w 1620 roku na terenie archidiecezji lwowskiej uległo zniszczeniu blisko 80 spośród około 120 istniejących wtedy kościołów. Ocalały 
jeźdźców. Tymczasem walki rozpoczęte na Rusi w 1648 roku trwały wiele lat, co hamowało akcję odnawiania zrujnowanych kościołów. Mimo to należy się spodziewać, że podejmowano próby przywracania do życia zniszczonych parafii oraz napraw obiektów sakralnych. Informacje dotyczące drugiej połowy XVII wieku, którymi dysponujemy nie pozwalają na zbudowanie całościowego obrazu wydarzeń. Tym niemniej wiemy, że także w tym trudnym okresie funkcjonowały do pewnego stopnia struktury Kościoła łacińskiego na obszarach diecezji kijowskiej. Przykładem wspomnianego zjawiska jest potwierdzona w literaturze, przypadająca na drugą połowę XVII wieku, działalność jezuitów należących do zniszczonego przez Kozaków kolegium kijowskiego. Jeden z zakonników pracował w Białej Cerkwi, zaś drugi, zapewne nielegalnie, w Kijowie ${ }^{27}$. Znajdujemy także całkiem zaskakujące wiadomości o funkcjonowaniu świątyń łacińskich nawet na obszarach zagarniętych przez Państwo Moskiewskie. Część z tych wiadomości można uznać za zwykłe pomyłki ${ }^{28}$, ale nie mamy powodu podważać wiarygodności przekazu K. Orłowskiego, który wyraźnie podał, że w jego czasach (ad presens) działał konwent kapucynów w Nieżynie, gdzie przed powstaniem Chmielnickiego istniał klasztor dominikanów ${ }^{29}$.

Najtrwalszym punktem sieci kościelnej na terenie diecezji kijowskiej w drugiej połowie XVII i pierwszej połowie XVIII wieku wydaje się być Biała Cerkiew. Po przejściu mieszczan na stronę Chmielnickiego miasto zostało odzyskane przez Polaków w 1658 roku i skutecznie przez nich bronione w następnych la-

tylko 43 świątynie. W. Urban, Z dziejów sokolnickiej królewszczyzny, Rzym 1964, s. 20; W. Szetelnicki, Trembowla. Kresowy bastion wiary i polskości, Wrocław 1992, s. 114.

${ }^{27}$ Encyklopedia wiedzy o jezuitach na ziemiach Polski i Litwy 1564-1995, opr. L. Grzebień, Kraków 1996, s. 279.

${ }^{28}$ Przykładem jest informacja dotycząca rzekomego funkcjonowania w drugiej połowie XVII i w XVIII wieku kościoła jezuitów w Nowogrodzie Siewierskim, podana przez SGKP, t. 7, s. 254255. Jest to informacja dotycząca $w$ istocie innego miejsca. Wskazuje na to już brak w opisie wydarzeń związanych z buntem kozackim i wkroczeniem Moskali. Pojawia się za to informacja o pożarze zabudowań jezuickich, który miał miejsce w 1651 roku. Miejscowy pleban ks. Gradowski miał wówczas umieścić szkołę w prebendzie, a potem tutejszą rezydencję jezuicką miał „obsypać łaskami” Michał Korybut Wiśniowiecki, a podkanclerzy Wielkiego Księstwa Litewskiego miał wystawić kościół. Dalej podano wiadomości, że po wojnach rezydencja jezuicka została przekształcona w kolegium, do czego „przyczynił się” podstoli Wielkiego Księstwa Litewskiego Michał Potocki z żoną Barbarą z Duninów, do końca XVII wieku jezuici prowadzili tu szkoły niższe, zaś w XVIII wieku aż do kasaty - szkoły wyższe. Stanisław Bednarski zaprzecza istnieniu placówki jezuickiej na terenie utraconym przez Rzeczpospolitą. Winą za pomyłkę obarcza Łukaszewicza, który wyliczając szkoły jezuickie 6 z nich pominął (J. Łukaszewicz, Historja szkót w Koronie $i$ Wielkim Księstwie Litewskim od najdawniejszych czasów aż do roku 1794, t. 4, Poznań 1851), a jednocześnie na s. 121 wymienił kolegium w Nowogródku Siewierskim. Bednarski stwierdził, że kolegium w Nowogrodzie Siewierskim ,istniało bardzo krótko, bo tylko do roku 1646”, a Łukaszewicz pomieszał Nowogród Siewierski z Nowogródkiem Litewskim (gdzie także działało kolegium jezuickie) i przypisał wydarzenia dotyczące Nowogródka Litewskiego Nowogrodowi Siewierskiemu (np. działalność szkoły wydziałowej w czasach KEN). Zob. S. Bednarski, Upadek i odrodzenie szkót jezuickich w Polsce. Studjum z dziejów kultury i szkolnictwa polskiego, Kraków 1933, s. 112, przypis 1.

${ }^{29}$ Defensa Biskupstwa, s. 169. 
$\operatorname{tach}^{30}$. W Białej Cerkwi pojawili się w tym czasie jezuici, którzy jako pierwsi przywrócili tu działalność łacińskiej świątyni, a także prowadzili parafię ${ }^{31}$. Sprowadził ich w 1664 roku Jan Stachurski jako misjonarzy obozowych działających wśród wojska polskiego przy kaplicy zamkowej. Powstała w ten sposób stacja misyjna podlegająca kolegium w Ostrogu ${ }^{32}$. Od 1667 roku istniał też w Białej Cerkwi kościół i klasztor augustianów ${ }^{33}$. W latach osiemdziesiątych XVII wieku biskup kijowski Andrzej Załuski zamierzał wznieść w mieście katedrę (po trwałej utracie Kijowa przez Polskę). Otrzymał na to nawet zgodę królewską. Zamiar jednak nie doszedł do skutku wobec ruiny miasta i stałego zagrożenia ze strony Kozaków $^{34}$. Od 1686 roku tutejsza misja jezuicka podlegała już nie kolegium ostrogskiemu lecz rezydencji w Owruczu ${ }^{35}$. W 1702 roku Biała Cerkiew została opanowana przez Kozaków Paleja i powróciła pod panowanie polskie dopiero w 1712 roku $^{36}$. Odtąd nie ma śladu istnienia w mieście placówki augustianów, lecz już w 1714 roku ponownie potwierdzone jest funkcjonowanie parafii prowadzonej przez jezuitów. Tutejszy kościół miał być jedyną istniejącą w tym czasie łacińską świątynią na Ukrainie ${ }^{37}$. Być może jego stan był nie najlepszy, skoro miejscowa szlachta w 1715 roku przeznaczyła sumę na naprawę dachu świątyni ${ }^{38}$. Świątynia została zapewne wizytowana i obdarowana przez biskupa Samuela Ożgę około 1724 roku $^{39}$. W 1732 roku wzniesiono nowe zabudowania dla misji jezuickiej, a w latach 1731-1733 zbudowano także drewniany kościół. Fundatorem obydwu budowli był wojewoda rawski i starosta białocerkiewski Stanisław Wincenty Jabłonowski. Pozwoliło to jezuitom przenieść się z zamku do miasta ${ }^{40}$. W kilka lat później stan misji jezuickiej w Białej Cerkwi określono jako „kwitnący"41. Początkowo składała się ona z superiora i dwóch misjonarzy, a w następ-

${ }^{30}$ E. Rulikowski, Opis powiatu wasylkowskiego pod względem historycznym, obyczajowym i statystycznym, Warszawa 1853, s. 95; Słownik geograficzny Królestwa Polskiego i innych krajów słowiańskich, t. 1-15, Warszawa 1880-1895 (dalej: SGKP), t. 1, s. 176, 178; J. Wojciechowska-Żywultowa, Biała Cerkiew. Ksiązka pamiątkowa białocerkiewian, Warszawa 1939, s. 15.

${ }^{31}$ Rulikowski, Opis, s. 96.

${ }^{32}$ Encyklopedia wiedzy, s. 39.

${ }^{33}$ Rulikowski, Opis, s. 97; SGKP, t. 1, s. 177.

${ }^{34}$ Długosz, Z dziejów, s. 13.

${ }^{35}$ Encyklopedia wiedzy, s. 39.

${ }^{36}$ SGKP, t. 1, s. 177, 179; Wojciechowska-Żywultowa, Biała Cerkiew, s. 15.

${ }^{37}$ Wojciechowska-Żywultowa, Biała Cerkiew, s. 25-26.

${ }^{38}$ SGKP, t. 1, s. 177.

${ }^{39}$ Defensa Biskupstwa, s. 111.

${ }^{40}$ Starsze prace podają 1743 rok jako datę budowy nowej rezydencji. Tymczasem nowsza literatura podaje rok 1732 jako budowę pierwszej rezydencji w mieście, zaś na lata 1761-63 datuje wzniesienie rezydencji murowanej. Kwestią sporną jest też materiał, z którego był zbudowany kościół. SGKP, t. 1, s. 52 przekazuje wiadomość o budowie murowanej świątyni. Natomiast inne, jak się wydaje bardziej wiarygodne, przekazy wskazują na fakt, że była ona drewniana. Zob. Stan, k. 17v; Rulikowski, Opis, s. 96; Encyklopedia wiedzy, s. 39.

${ }^{41}$ SGKP, t. 1, s. 177. 
nych latach ich liczba rosła ${ }^{42}$. Rozległa parafia (należało do niej pięć starostw) prowadzona przez jezuitów z tutejszej misji została odnotowana w czasie wizytacji z lat 1746-174843. Nowy kościół został konsekrowany przez biskupa Kajetana Sołtyka 3 XII 1751 roku. Oprócz niego w latach sześćdziesiątych XVIII wieku w Białej Cerkwi istniały także dwie kaplice. Jedna znajdowała się w obrębie tutejszej fortecy, druga mieściła się w stojącym obok niej zamku starościńskim ${ }^{44}$. W 1767 roku odnotowano istnienie, znajdującego się pod zarządem jezuitów, kościoła w Białej Cerkwi. Jego rektorem był Konstanty Awedyk ${ }^{45}$. Po kasacie jezuitów w 1773 roku ich drewniany kościół został zamieniony na farę, lecz biskup Józef Andrzej Załuski zabiegał o pozostanie eks-zakonników w mieście. Kolejnym fundatorem świątyń w Białej Cerkwi był hetman wielki koronny Franciszek Ksawery Branicki, który w 1774 roku otrzymał starostwo białocerkiewskie. Wkrótce potem (zapewne około 1775 roku) wzniósł na posadzce dawnego zamku nowy kościół parafialny, zaś w 1779 roku zapisał na świątynię sumę 2 tysięcy $\mathrm{złotych}^{46}$. Mimo to były kłopoty z utrzymaniem kościoła parafialnego w Białej Cerkwi, co wynikało prawdopodobnie z faktu, że jego uposażeniem były dawne dobra jezuickie. Bez wątpienia powodowało to problemy $w$ ich zarządzaniu. W 1780 roku zawarto konkordat między dysponującą tymi dobrami Komisją Edukacji Narodowej a biskupem i kapitułą kijowską. Kapituła, która otrzymała kościół wraz z prawem patronatu, zobowiązała się utrzymywać w Białej Cerkwi dwóch kapłanów (którym miała płacić 3 tysiące złotych) oraz szkołę parafialną (dyrektor szkoły miał otrzymywać 200 złotych), lecz w następnych latach nie wypłacała pieniędzy i księża pozostawali bez utrzymania. W 1782 roku odnotowano istnienie drewnianego kościoła parafialnego fundowanego przez starostę Jabłonowskiego dla misjonarzy jezuickich, odstąpionego następnie biskupom kijowskim i kapitule, „opatrzonego” przez hetmana Branickiego. Plebanem był honorowy kanonik kapituły kijowskiej Kazimierz Toczyski, który miał murowane mieszkanie przy kościele. Istniała też szkółka parafialna z nauczycielem klerykiem Korsakiem ${ }^{47}$. Hetman Branicki w tym okresie nadal wspierał materialnie

${ }^{42}$ Od 1735 roku było trzech misjonarzy, od 1737 roku - czterech, od 1740 - pięciu. Encyklopedia wiedzy, s. 39.

${ }^{43}$ Defensa Biskupstwa, s. 143-144; Rulikowski, Opis, s. 96; Heleniusz [Iwanowski], Wspomnienia, s. 267, 269-270, 297.

${ }^{44}$ SGKP, t. 1, s. 177.

${ }^{45}$ Statua, s. [679, 680].

${ }^{46}$ Rulikowski, Opis powiatu, s. 96; SGKP, t. 1, s. 178; Wojciechowska-Żywultowa, Biała Cerkiew, s. 26. W przypadku świątyni wzniesionej przez F. Branickiego nie mamy pewności czy była murowana czy raczej drewniana. O budowie murowanego kościoła parafialnego mówił Rulikowski, Opis, s. 97, 108. Natomiast pochodzące z XVIII wieku przekazy wskazują na istnienie drewnianego kościoła i to zapewne tego samego, który stał wcześniej i został jedynie „opatrzony” przez Branickiego. Zob. Pałucki, Stan, k. 17v.

${ }^{47}$ Pałucki, Stan, k. 12v, 17v, 19v; SGKP, t. 1, s. 178; Komisya Edukacyi Narodowej i jej szkoty $w$ Koronie, wyd. T. Wierzbowski (dalej: KENSK), z. 38: Protokoły posiedzeń Komisyi Edukacyi Narodowej 1778-1780, Warszawa 1913, s. 22; T. Wierzbowski, Szkoły parafjalne w Polsce i na Litwie za czasów Komisji Edukacji Narodowej 1773-1794, Kraków 1921, s. 119; H. Pohoska, Wizyta- 
tutejszą parafię. W 1789 roku przeznaczył on kolejną sumę na utrzymanie kościoła i księży ${ }^{48}$.

Stałym elementem sieci kościelnej diecezji kijowskiej obrządku łacińskiego pozostawał w omawianym okresie położony w jej północno-zachodniej części Olewsk. Kościół parafialny istniejący tu przed powstaniem Chmielnickiego ${ }^{49}$ uległ zapewne zniszczeniu, lecz stosunkowo szybko podjęto kroki zmierzające do przywrócenia funkcjonowania świątyni. W 1669 roku Józef Karol Namierzycz (Niemierzycz, Niemirycz) fundował w Olewsku drewniany kościół de nova radice pod wezwaniem Zwiastowania NMP wraz z klasztorem karmelitów trzewiczkowych przewidzianym na 12 zakonników. Fundator bardzo hojnie uposażył klasztor nadając mu miasteczko i inne grunty. Po jego śmierci spadkobiercy usiłowali podważyć zapis, co było przyczyną długotrwałego, trwającego aż do 1683 roku, procesu. W tym czasie zakonnicy byli dwukrotnie wypędzani z Olewska, ostatecznie jednak zdołali się w nim utrzymać. Po zawarciu zgody syn fundatora Eliasz Aleksander Niemirycz zbudował nowy (sosnowy, tak jak poprzedni) kościół. W 1712 roku powstał już klasztor, a zakonnicy otrzymali zarząd parafii ${ }^{50}$. W latach 1746-1748 tutejszy kościół także był traktowany jak świątynia parafialna. Karmelici trzewiczkowi prowadzili parafię, która nie miała wyraźnie oznaczonego okręgu i obejmowała „całą okolicę" 51 , którą zapewne należy rozumieć jako północno-zachodni obszar diecezji sięgający aż do parafii wielednickiej na wschodzie. W latach 1758-1763 wzniesiono kolejny nowy budynek kościoła. W tym czasie placówka była wspierana zapisami okolicznej szlachty. Do parafii w 1777 roku należało 102 wiernych ${ }^{52}$. Tutejsza świątynia parafialna znalazła się wśród kościołów wymienionych w spisie z 1767 roku. Zapisano wówczas, że prawo patronatu kościoła należało do Niemierzyców, parafia znajdowała się w zarządzie karmelitów trzewiczkowych, a na czele miejscowych duchownych stał ksiądz Jemiołkowski ${ }^{53}$. Istnienie drewnianego kościoła karmelitów trzewiczkowych fundo-

torowie generalni Komisji Edukacji Narodowej. Monografia z dziejów administracji szkolnej Komisji Edukacji Narodowej, Lublin 1957, s. 318.

${ }^{48}$ SGKP, t. 1, s. 178.

${ }^{49}$ Pałucki, Stan, k. 15v; Heleniusz [Iwanowski], Wspomnienia, s. 267, 296.

${ }^{50}$ Pałucki, Stan, k. 18v; Encyklopedja kościelna, t. 10, s. 41; SGKP, t. 7, s. 480 (gdzie podano, że proces spadkobierców fundatora z zakonnikami zakończył się w 1693 roku, ale hasło w Słowniku było bez wątpienia opracowane na podstawie wiadomości z Encyklopedji kościelnej); Wołyniak [J. M. Giżycki], Zniesione kościoły i klasztory rzymsko-katolickie przez rzad rosyjski w wieku XIXtym $w$ diecezji łuckiej, żytomierskiej i kamienieckiej (gub. wołyńskiej, kijowskiej i podolskiej), [wyd.] J. Fijałek, - Nova Polonia Sacra, t. 1, Kraków 1928, s. 196-197. SGKP podał wezwanie Podwyższenia Krzyża Świętego, które zapewne było wezwaniem późniejszym.

${ }^{51}$ Defensa Biskupstwa, s. 149; Heleniusz [Iwanowski], Wspomnienia, s. 267, 272, 297. Winą za taki stan rzeczy Giżycki obarcza karmelitów, którzy nie stawiali się na wezwania biskupa mające na celu rozgraniczenie parafii (Wołyniak [Giżycki], Zniesione, s. 197).

${ }^{52}$ Wołyniak [Giżycki], Zniesione, s. 197-198.

${ }^{53}$ Statua, s. [680]. 
wanego przez Józefa Karola Namierzycza odnotowano w Olewsku także w 1782 $\mathrm{roku}^{54}$.

Nieudaną próbę odnowienia dawnego ośrodka jezuickiego podjęto w drugiej połowie XVII wieku w Ksawerowie. Od 1634 roku funkcjonowała w tym mieście rezydencja jezuitów, choć nie udało się zrealizować zamierzeń rozszerzenia jej do rozmiarów kolegium (placówkę określano jako collegium inchoatum). W czasie powstania Chmielnickiego zamknięto tutejszą szkołę, a w następnym okresie w rezydencji pozostawał tylko jej założyciel - jezuita Ignacy Jelec. Taki stan rzeczy miał miejsce do 1654 roku, zaś po tej dacie rezydencja całkowicie zanikła. W 1664 roku ponownie wzniesiono rezydencję w Ksawerowie, ale w 1670 roku znów przestała ona istnieć. Ostatecznie sejm w 1678 roku przeniósł jej siedzibę do Owrucza, a na miejscu istniała później tylko stacja rezydencji owruckiej $^{55}$. Była ona odnotowana jeszcze w 1767 roku $^{56}$, co może oznaczać, że działała aż do kasaty zakonu.

Tradycje jezuickiego ośrodka ksawerowskiego kontynuował Owrucz, który stał się w XVIII wieku jednym z ważniejszych ośrodków kościelnych na obszarze diecezji kijowskiej. Miasto, spalone w 1648 roku wraz z kościołami przez Tatarów i Kozaków, szybko podniosło się ze zniszczeń. Działał tu w tym czasie kościół i klasztor dominikanów, który powstał jeszcze przed powstaniem Chmielnickiego. Dopiero 1670 rok przyniósł poważne zaburzenia w funkcjonowaniu tutejszego ośrodka kościelnego. Dominikanie zostali wypędzeni z miasta przez Tatarów, a ich klasztor ,zachwiał się w bycie" ${ }^{57}$. Mimo to Owrucz musiał uchodzić w latach siedemdziesiątych XVII wieku za miejsce w miarę spokojne, skoro w 1678 roku, na wniosek szlachty, sejm zdecydował ulokować tu kolegium jezuickie, istniejące wcześniej w Ksawerowie. Jako pierwszy jezuita pojawił się w mieście Hieronim Eytmin z Ostroga, który w 1682 roku zaczął pracę przy tymczasowym kościele wzniesionym przez szlachtę i mieszczan. Dwa lata później powstała w Owruczu rezydencja jezuicka. Zakonnicy uruchomili tu ,szkoły niższe" i choć wskutek ciągłych niepokojów rozwój tutejszej rezydencji (od 1741 roku zamienionej na kolegium) oraz szkół były powolne, to jednak samo ich ist-

${ }^{54}$ Pałucki, Stan, k. 18v. W 1832 roku klasztor został skasowany, a kościół został zamieniony na świątynię parafialną. Zob.: SGKP, t. 7, s. 480. Odrzucamy podaną przez E. Iwanowskiego (Wspomnienia, s. 321) informację o fundowaniu w Olewsku, za zezwoleniem biskupa łuckiego Franciszka Kobielskiego, kościoła i klasztoru kapucynów (musiałoby to nastąpić w okresie 1739-1755). Nie wydaje się prawdopodobne, aby biskup łucki decydował w sprawach sąsiedniej diecezji. Błąd Iwanowskiego polega na pomyleniu Olewska z leżącym w województwie ruskim, dekanacie krzemienieckim diecezji łuckiej Oleskiem, gdzie rzeczywiście w 1739 roku powstał klasztor kapucynów. Zob.: M. Sobieraj, Fundatorzy klasztorów franciszkańskich w Rzeczypospolitej XVI-XVIII wieku, (w:) Zakony franciszkańskie w Polsce, red. J. Kłoczowski, t. 2: Franciszkanie w Polsce XVI-XVIII wieku, cz. 1, Niepokalanów 1998, s. 240.

${ }^{55}$ Encyklopedia wiedzy, s. 339.

${ }^{56}$ Statua, s. [680].

${ }^{57}$ SGKP, t. 7, s. 776-777; [J. M. Giżycki], Spis ważniejszych miejscowości w powiecie starokonstantynowskim na Wołyniu, Stary Konstantynów 1910, s. 403; Wołyniak [Giżycki], Zniesione, s. 184. Istniała legenda, że pierwszy klasztor dominikanów w Owruczu założył św. Jacek w XIII wieku. 
nienie świadczy o trwałości ośrodka owruckiego jako ogniwa sieci kościelnej diecezji kijowskiej. W latach 1714-1715 dawny tymczasowy kościół zastąpiono nową drewnianą świątynią ${ }^{58}$. Jezuici zastąpili miejsce dominikanów w Owruczu. Moment pojawienia się ich w mieście w 1682 roku zbiegł się z ostatnią w tym okresie wzmianką dotyczącą owruckich dominikanów. W 1682/1683 roku występował dominikanin Jacek Trzaska, który był zapewne przeorem czarnobylskim i jednocześnie stał na czele placówki owruckiej. Już sam fakt łączenia dwóch funkcji wskazuje na upadek samodzielności dominikańskiego ośrodka owruckiego $^{59}$. Dopiero w 1723 roku chorąży żytomierski Stanisław Wentury Hański zapisał dominikanom 15 tysięcy złotych na wsi Jackiewiczach, a Bonawentura Hański przeznaczył na ich klasztor 10 tysięcy złotych. W 1740 roku szlachta domagała się zatwierdzenia funduszy dominikanów ${ }^{60}$, ale sam klasztor zapewne już wówczas funkcjonował. Przemawiają za tym nieco późniejsze przekazy świadczące o tym, że w latach 1746-1748 w mieście istniały klasztory jezuitów i dominikanów, zaś dominikanie prowadzili jednocześnie parafię obejmującą 54 osady. W trakcie organizacji była wtedy leżąca na terenie parafii owruckiej, parafia w Nowych Narodyczach, gdzie był już fundowany kościół ${ }^{61}$. W tym okresie Owrucz był stolicą dekanatu obejmującego północne obszary diecezji kijowskiej, wcześniej zaliczane do dekanatu wielednickiego ${ }^{62}$. W następnych latach znajdujemy kolejne ślady funkcjonowania Owrucza jako ważnego punktu sieci kościelnej diecezji kijowskiej. W roku 1745 spłonęły drewniane budynki kolegium i kościoła jezuitów. W 1747 roku położono kamień węgielny pod budowę nowej świątyni, lecz w 1753 roku przeniesiono ją w inne miejsce i ostatecznie ukończono dopiero w 1769 roku. Odbudowę kolegium rozpoczęto w 1760 roku. Wznoszono murowany dwupiętrowy budynek, którego nie zdołano ukończyć przed kasatą zakonu ${ }^{63}$. Parafia owrucka, pozostająca pod zarządem dominikanów, została odnotowana w spisie z 1767 roku. Zapisano wówczas, że prawo patronatu należało do miejscowego starostwa, a na czele parafii stał ksiądz Feliks Wilkowski ${ }^{64}$. Kościół dominikanów będący jednocześnie świątynią parafialną korzystał w tym okresie ze wsparcia lokalnej społeczności łacińskiej. Swiadczy o tym fakt, że w 1752 roku tutejsza szlachta przeznaczyła na jego potrzeby tysiąc złotych. W 1768 roku do

${ }^{58}$ T. J. Stecki, Wotyń pod względem statystycznym, historycznym i archeologicznym, t. 1, Lwów 1864, s. 143; SGKP, t. 7, s. 777. Szkoły niższe w Owruczu działały praktycznie przez cały okres XVIII wieku aż do momentu kasaty zakonu jezuitów w 1773 roku. Zob. S. Bednarski, Upadek, tablica II, V; Encyklopedia wiedzy, s. 485.

${ }^{59}$ Wołyniak [Giżycki], Zniesione, s. 184-185.

${ }^{60}$ SGKP, t. 7, s. 779.

${ }^{61}$ Defensa Biskupstwa, s. 146-146v (Orłowski wymienił w sumie 54 osady w okręgu parafialnym, ale pomylił się w ich numeracji dwukrotnie podając numer 37); Heleniusz [Iwanowski], Wspomnienia, s. 267, 271, 297 (autor podaje 53 osady w okręgu parafialnym zgodnie z numeracją podaną przez Orłowskiego).

${ }^{62}$ Defensa Biskupstwa, s. 146-149v; Heleniusz [Iwanowski], Wspomnienia, s. 267, 271-272. SGKP, t. 7, s. 779 błędnie datuje utworzenie dekanatu owruckiego na 1777 rok.

${ }^{63}$ Encyklopedia wiedzy, s. 485.

${ }^{64}$ Statua, s. [680]. 
parafii owruckiej należały wciąż jeszcze 54 wsie, a w 1777 roku miała ona 372 wiernych $^{65}$. Po kasacie jezuitów działała nadal tutejsza szkoła. Była szkołą podwydziałową, początkowo akademicką, potem zaś została przekazana bazylianom $^{66}$. W 1782 roku dziekanem owruckim był kanonik honorowy kapituły kijowskiej Samuel Modliszewski ${ }^{67}$. W mieście istniały dwa kościoły. Drewniany (choć z zaczętymi murami) kościół dominikanów posiadający cura animarum istniejący „na miejscu starodawnym” oraz murowany kościół akademicki, hojnie fundowany przez sufragana i oficjała kijowskiego Jelca dla jezuitów, a po kasacie zakonu, z racji istnienia przy nim szkół publicznych, wzięty pod opiekę KEN. Przy tym kościele istniała nowa szkoła ${ }^{68}$. Kościół pojezuicki w 1783 roku oddano bazylianom ${ }^{69}$. W latach osiemdziesiątych kontynuowano zapewne podnoszenie murów świątyni dominikańskiej, skoro istnieje przekaz o wzniesieniu w 1790 roku nowego murowanego kościoła dominikanów pod wezwaniem Wniebowzięcia NMP ${ }^{70}$.

Także z jezuitami wiąże się powstanie kolejnego punktu sieci kościelnej w diecezji kijowskiej. Punktem tym były Jurewicze. Pierwsza drewniana kaplica została tu wzniesiona przez misjonarza obozowego i ludowego Marcina Tyrawskiego w 1673 roku $^{71}$. W 1674 roku Barbara z Judyckich Łoszczyna zapisała na połowie wsi Jurewicze 20 tysięcy złotych na kolegium w Owruczu. Jednocześnie Marianna Kotarska ofiarowała drugą połowę wsi. Prowincjał jezuitów Bartłomiej Wąsowski przeznaczył całą wieś na uposażenie stacji misyjnej w samych Jurewiczach, ale dochody nie starczały na utrzymanie misji i musiano je powiększać. Około 1681 roku zbudowano drewniany kościół i dom dla misjonarzy. Pierwotnie pracował tu tylko jeden zakonnik, zaś od 1698 roku dwóch misjonarzy z rezydencji w Owruczu ${ }^{72}$. W latach 1746-1748 tutejsza misja pełniła rolę parafii, do której należało osiem $\mathrm{wsi}^{73}$. W latach 1746-1755 zbudowano murowany kościół, który w 1765 roku został konsekrowany pod wezwaniem Nawiedzenia NMP. W tym samym czasie zbudowano piętrowy murowany dom dla zakonników. Od 1755 roku jezuicka placówka w Jurewiczach miała już rangę rezydencji ${ }^{74}$. W 1767 roku odnotowano w Jurewiczach parafię i rezydencję jezuitów ze szkołą. Rektorem kościoła był Andrzej Grądzki ${ }^{75}$. Jezuici uruchomili wspomnianą szkołę w Jurewi-

${ }^{65}$ Wołyniak [Giżycki], Zniesione, s. 185.

${ }^{66}$ SGKP, t. 7, s. 779.

${ }^{67}$ Pałucki, Stan, k. 12v.

${ }^{68}$ Pałucki, Stan, k. 18. Wołyniak [Giżycki], Zniesione, s. 185 podał, że kościół dominikanów zaczęto murować w 1789 roku, co jest niezgodne z przekazem Pałuckiego.

${ }^{69}$ Encyklopedia wiedzy, s. 485. Podano tam także wiadomość, że w latach 1773-1783 był to kościół parafialny, co jest sprzeczne z przekazem M. Pałuckiego z 1782 roku. Świątynia po kasacie bazylianów w 1831 roku opustoszała i została rozebrana.

${ }^{70}$ SGKP, t. 7, s. 780.

${ }^{71}$ Encyklopedia wiedzy, s. 257. Tymczasem SGKP, t. 3, s. 630 datuje powstanie misji jezuickiej i początek budowy kościoła dopiero na 1726 rok.

${ }^{72}$ Encyklopedia wiedzy, s. 256-257.

${ }^{73}$ Defensa Biskupstwa, s. 148v; Heleniusz [Iwanowski], Wspomnienia, s. 272, 297.

${ }^{74}$ Encyklopedia wiedzy, s. 256-257.

${ }^{75}$ Statua, s. [680]. 
czach po 1756 roku jako szkołę niższą ${ }^{76}$, a po kasacie zakonu pozostali przy kościele i uczyli aż do 1781 roku $^{77}$. Ostatecznie w 1782 roku pojezuicka szkoła jurewicka została przeniesiona do pobliskiego Mozyrza na Litwie, a biskup Franciszek Ossoliński na miejsce jezuitów sprowadził misjonarzy kapucyńskich, którym oddał tutejszy kościół i klasztor ${ }^{78}$. W 1782 roku opisano w Jurewiczach murowany kościół fundowany niegdyś przez Stockich i „Niemstów sióstr rodzonych, staraniem księdza Marcina Tyrawskiego misjonarza ukraińskiego" dla jezuitów, który był „w swoim czasie hojnie nadany i wcale pięknie zbudowany”. Po kasacie jezuitów kościół miał być odstąpiony przez KEN biskupowi kijowskiemu, a przez niego kapucynom z obowiązkiem odprawiania w ciągu roku trzech misji na terenie diecezji oraz $\mathrm{z}$ dodaniem cura animarum parafii jurewickiej. Przy kościele istniały murowany klasztor $\mathrm{i}$ inne zabudowania, a świątynia słynęła cudownym obrazem Matki Boskiej ${ }^{79}$. Kapucyni wraz z przejęciem parafii uruchomili ponownie szkołę, która została odnotowana w 1783 roku $^{80}$. Doprowadzili także do pozwania przez konsystorz kijowski prorektora szkoły mozyrskiej przed sąd Komisji Edukacji Narodowej o zabór części sprzętów kościelnych. Okazało się jednak, że stało się to za wiedzą KEN ${ }^{81}$. Kapucyni nie utrzymali się długo w Jurewiczach. Już w 1788 roku zastąpili ich dominikanie, a w końcu w 1800 roku - bernardy$\mathrm{ni}^{82}$.

Kolejnym miastem stanowiącym ważny element sieci kościelnej diecezji kijowskiej był Żytomierz. Po trwałej utracie przez Polskę Kijowa i po fiasku prób ustanowienia nowej katedry w Białej Cerkwi Żytomierz od lat dwudziestych XVIII wieku stał się faktyczną stolicą diecezji, siedzibą biskupa i kapituły kijowskiej. W czasie powstania Chmielnickiego istniejące tu wcześniej kościoły zostały

${ }^{76} \mathrm{~S}$. Bednarski, Upadek, tablica II, V. Szkoły jurewickiej brak jeszcze w zestawieniach z roku 1756. Pojawia się po raz pierwszy w roku 1767/8.

${ }^{77}$ M. Gozdawa [J. M. Giżycki], Luźne kartki z przeszłości. Mozyrz, Odbitka z „Kwartalnika Litewskiego", [po 1910], s. 84.

${ }^{78}$ Pałucki, Stan, k. 11, 18v-19; Heleniusz [Iwanowski], Wspomnienia, s. 452; Gozdawa [Giżycki], Luźne kartki, s. 84.

${ }^{79}$ Pałucki, Stan, k. 18v-19.

${ }^{80}$ Gozdawa [Giżycki], Luźne kartki, s. 84; Wierzbowski, Szkoty parafjalne, s. 209; Pohoska, Wizytatorowie generalni, s. 321, 346; Raporty generalnych wizytatorów szkót Komisji Edukacji Narodowej w Wielkim Księstwie Litewskim (1782-1792), opr. K. Bartnicka i I. Szybiak, Wrocław-Warszawa-Kraków-Gdańsk 1974, s. 144.

${ }^{81}$ Raporty generalnych wizytatorów, s. 29.

${ }^{82}$ Encyklopedia wiedzy, s. 257. W 1832 roku po kasacie klasztoru bernardynów kościół został przekształcony w świątynię parafialną. SGKP, t. 3, s. 630 zawiera błędną wiadomość, że bernardyni mieli się tu pojawić jeszcze przed kapucynami. M. Sobieraj (Fundatorzy, s. 97-243) nie podaje żadnej informacji o placówce bernardynów lub kapucynów w Jurewiczach. Być może zatem nie był to samodzielny klasztor, lecz sprowadzono tylko kilku zakonników w celu powierzenia im tutejszej misji z pobliskiego klasztoru bernardynów w Mozyrzu, albo nieco dalej położonych w Cudnowie lub Żytomierzu. Ponieważ kapucynów sprowadził biskup kijowski wydaje się prawdopodobnym, że zakonnicy przybyli z klasztoru w Chodorkowie lub Brusiłowie. 
zniszczone przez Kozaków ${ }^{83}$. Miejsce po kościele parafialnym zarosło, a częściowo było zajęte przez „nędzne chaty” mieszkańców ${ }^{84}$. Pierwszą, nie wiemy czy udaną, próbę przywrócenia kościoła katolickiego w Żytomierzu podjął wojewoda kijowski Janusz Tyszkiewicz już w drugiej połowie XVII wieku. Fundował on kościół i klasztor karmelitów bosych. Nie wiadomo jednak czy w ogóle doszło do osiedlenia się zakonników w mieście. Kościól, który wzniesiono na dawnym miejscu cerkwi spaskiej uległ zniszczeniu pod koniec stulecia ${ }^{85}$. Istotną datą w procesie odbudowy ośrodka kościelnego w Żytomierzu był 1724 rok. Zebrana na sejmiku szlachta ustanowiła wtedy 8 tysięcy złotych na ufundowanie katedry i wskazała biskupowi Samuelowi Ożdze miejsca, gdzie dawniej istniały kościoły. Szczególnie ważne było miejsce na górze koło zamku, zwane kościeliskiem, na którym stał niegdyś parafialny kościół NMP ${ }^{86}$. Biskup oczyścił to miejsce, wystawił na nim figurę, odprawił mszę w namiocie i rozpoczął odbudowę kościoła pod wezwaniem Wniebowzięcia NMP ${ }^{87}$. Już wtedy zapewne zapadła decyzja o ustanowieniu nowej stolicy diecezji kijowskiej w Żytomierzu, bowiem to tu biskup sprowadził z Lublina rozproszoną wcześniej kapitułę telan kijowski, starosta żytomierski Kazimierz Stecki fundował misję jezuicką w Żytomierzu oraz zbudował dla zakonników tymczasową drewnianą świątynię. Placówka jezuitów stanowiła wzmocnienie nowego ośrodka kościelnego, a wkrótce uruchomiono przy niej także szkoły niższe ${ }^{89}$. Kościół parafialny ukończono już w 1725 roku, a w następnym roku poświęcono. Był on jednak wznoszony w pośpiechu i wadliwie, więc szybko zaczął się walić. Biskup Ożga wkrótce oddał go

\footnotetext{
${ }^{83}$ Według dziewiętnastowiecznych przekazów pierwszą świątynię katolicką wraz z klasztorem dominikanów założył w Żytomierzu św. Jacek. Miała ona zostać zniszczona przez Tatarów w 1240 roku i nie odbudowana, a na jej miejscu stanęła cerkiew bazyliańska. W XV wieku, gdy Żytomierz zaliczał się do 15 największych miast Litwy, istniały w nim dwa kościoły: parafialny pod wezwaniem NMP, gdzie później stała katedra oraz inny pod wezwaniem św. Mikołaja, na przedmieściu Kokrynie, gdzie istniał cmentarz. Uposażeniem kościoła NMP była wieś Iwanowce (Iwanowicze) leżąca 4 mile od Żytomierza, zaś uposażeniem kościoła św. Mikołaja - wieś Popowicze (Popówka). Kościół parafialny funkcjonował w Żytomierzu także w pierwszej połowie XVII wieku. Zob.: Stan, k. 15v-16, 22-23; F. N. [F. Nowicki], Wotyń i jego mieszkańce w r. 1863. Krótkie opisanie gubernii Wotyńskiej pod względem jeograficznym i statystycznym, Drezno 1870, s. 13-14; SGKP, t. 14, s. 903904; Heleniusz [Iwanowski], Wspomnienia, s. 262, 266, 296.

${ }^{84}$ Pałucki, Stan, k. 23.

${ }^{85}$ SGKP, t. 14, s. 903.

${ }^{86}$ Pałucki, Stan, k. 22v.

${ }^{87}$ Pałucki, Stan, k. 23; SGKP, t. 14, s. 903.

${ }^{88}$ Defensa Biskupstwa, s. 109; Stan, k. 23v.

${ }^{89}$ T. J. Stecki, Wolyń pod względem statystycznym, historycznym i archeologicznym, t. 1, Lwów 1864, s. 144; F. N. [F. Nowicki], Wotyń, s. 14; SGKP, t. 14, s. 903 (gdzie jedynie wiadomość o fundowaniu przez Kazimierza Steckiego h. Radwan kościoła i klasztoru jezuitów); T. J. Stecki, $Z$ boru i stepu. Obrazy i pamiątki, wyd. 2, Kraków 1898, s. 102. Jezuicka niepełna szkoła niższa pojawia się po raz pierwszy w spisach S. Bednarskiego w 1750 roku (nie było jej jeszcze w 1740 roku) zob. Bednarski, Upadek, tablica II; Encyklopedia wiedzy, s. 805. Kasztelan kijowski Stecki został odnotowany jako fundator jezuitów przez Statua, s. [681].
} 
na kaplicę dla sprowadzonych przez Steckiego jezuitów ${ }^{90}$. Prawdopodobnie to właśnie ta świątynia pełniła rolę parafialnej aż do czasu wzniesienia nowej katedry. W 1732 roku biskup rozpoczął budowę nowego kościoła Wniebowzięcia NMP. Świątynię wzniósł w dużym stopniu własnym kosztem, a „,czego sam dać nie mógł - nakłonił swego koadjutora Józefa Łaszcza jako pana wielkiej fortuny". Kościół wznoszony z przeznaczeniem na katedrę został także przez biskupa Ożgę zaopatrzony w sprzęty i stałe fundusze ${ }^{91}$. Także budowa tej świątyni nie przebiegała bez zakłóceń. W 1737 roku trzęsienie ziemi, które miało miejsce na Ukrainie doprowadziło do uszkodzenia wznoszonej budowli ${ }^{92}$. W latach 1746-1748 odnotowano istnienie w Żytomierzu kościoła jezuitów oraz katedry, która była jednocześnie świątynią parafialną. Do parafii żytomierskiej należało wówczas 55 miejscowości ${ }^{93}$. W tym samym czasie zapewne ukończono już ostatecznie budowę katedry ${ }^{94}$, która została poświęcona 7 II 1751 roku przez koadjutora kijowskiego, biskupa emauskiego Kajetana Ignacego Sołtyka ${ }^{95}$. W następnych latach rosło znaczenie Żytomierza jako ośrodka sieci kościelnej. W 1754 roku biskup Sołtyk swoim kosztem wzniósł i wyposażył murowane seminarium oraz sprowadził z Warszawy misjonarzy św. Wincentego a Paulo ${ }^{96}$. W latach 1751-1762 wzniesiono nowy murowany kościół jezuitów (konsekrowany w 1762 roku przez biskupa Załuskiego), zaś w 1766 roku wzniesiono część ich rezydencji jednocześnie zakładając fundamenty pod dalszą część oraz pod szkoły ${ }^{97}$. Kolegium jezuickie zostało też odnotowane wśród kościołów diecezji kijowskiej w 1767 roku $^{98}$. W 1761 roku starosta żytomierski Jan Kajetan Iliński fundował kościół i klasztor bernardynów (fundator wzniósł drewniany kościół, zaś murowany klasztor zbudowano ze skła-

${ }^{90}$ Pałucki, Stan, k. 23.

${ }^{91}$ Pałucki, Stan, k. 23-23v. Literatura nie jest zgodna co do czasu budowy katedry, zawiera także rożne wersje wydarzeń związanych z samą budową. F. N. [F. N o w i c k i], Wotyń, s. 14 podał datę 1735 jako początek budowy. Nie podał daty budowy Heleniusz [Iwanowski], Wspomnienia, s. 262. Z kolei SGKP, t. 14, s. 903 przekazał wiadomość o rozebraniu w 1737 roku drewnianego kościoła i budowie przez biskupa Ożgę murowanej świątyni Wniebowzięcia NMP, przy której zostały osadzone kapituła i konsystorz. Jednocześnie na s. 909 pojawiła się informacja o ufundowaniu katedry w 1745 roku (!). Zapewne mamy do czynienia z pomyłką polegającą na przyjęciu za datę fundacji możliwego momentu zakończenia budowy. W stosunkowo najnowszej pracy Teofila Długosza ( $Z$ dziejów) przekazana jest wersja o tym, że pierwotnie budowano drewnianą katedrę na ruinach dawnego spalonego kościoła, lecz szybko zakończono źle zaczętą budowę i następnie wznoszono już świątynię z cegły (Tamże, s. 13). Ostatecznie uznajemy, że mamy do czynienia z pomieszaniem różnych wiadomości i dat i przyznajemy pierwszeństwo najbliższemu czasom budowy opisowi diecezji M. Pałuckiego.

${ }^{92}$ Defensa Biskupstwa, s. 164; Relacja o stanie, s. 153.

${ }^{93}$ Defensa Biskupstwa, s. 136-137; Heleniusz [Iwanowski], Wspomnienia, s. 267, 297.

${ }^{94}$ Datę 1746 podał F. Rawita-Gawroński, Kijów. Legendy, podania, dzieje. Studya i szkice historyczne. Serya 3, Kijów-Warszawa 1915, s. 37. Datę 1745 (błędnie jako datę fundacji) - SGKP, t. 14 , s. 909.

${ }^{95}$ F. N. [F. Nowicki], Wotyń, s. 14; SGKP, t. 14, s. 909.

${ }^{96}$ Pałucki, Stan, k. $23 \mathrm{v}$.

${ }^{97}$ Statua, s. [679, 681]; Encyklopedia wiedzy, s. 805.

${ }^{98}$ Statua, s. [680]. 
dek) ${ }^{99}$, a pięć lat później biskup kijowski Józef Andrzej Załuski sprowadził z Pułtuska siostry miłosierdzia (szarytki), którym oddał domek koło katedry ${ }^{100}$. Okres rozwoju zakończył się w 1768 roku, gdy w wyniku spowodowanego przez Moskali pożaru spłonęła część miasta, w tym niektóre świątynie i zabudowania kościelne. Zniszczeniu uległy katedra (z wyjątkiem kaplicy pełniącej potem jej funkcję), dom biskupi, wikariat, biblioteka i archiwum konsystorskie. Ocalał dom sióstr i według niektórych przekazów też kościół jezuitów ${ }^{101}$. Według innych źródeł także ta świątynia spłonęła. Została ona odbudowana w 1770 roku, ale nie wykończona ${ }^{102}$. Odbudowę katedry podjęto także około 1770 roku z biskupich funduszy stołowych, które przeznaczył na ten cel więziony przez Moskali w Kałudze biskup Józef Andrzej Załuski. W miarę możliwości odnowiono wtedy katedrę, wikariat i seminarium. Wzniesiono też nowy dom dla sióstr miłosierdzia ${ }^{103}$. Po kasacie jezuitów w 1773 roku ich kościół został zamknięty a budynki klasztorne przeznaczono na użytek szkół ${ }^{104}$. Zniszczenia, których dokonał pożar w katedrze musiały być duże, o czym świadczą liczne wiadomości dotyczące jej stanu w latach siedemdziesiątych XVIII wieku. Istnieje przekaz, że została ona odrestaurowana przez biskupa Franciszka Ossolińskiego ${ }^{105}$. Odbudowa nastąpiła zatem nie wcześniej niż w 1774 roku $^{106}$ ale prawdopodobnie także niewiele później ${ }^{107}$. W 1775 roku papież nakazał zbudować dom biskupi ${ }^{108}$, co wyraźnie wskazuje na fakt, że nie został on do tego momentu odbudowany. Krótko potem stwierdzono także, że katedra nie nadaje się do naprawy i należy wznieść nową ${ }^{109}$. W 1782 roku odnotowano istnienie trzech kościołów w Żytomierzu. Pierwszym

${ }^{99}$ Statua, s. [681] (bez daty); F. N. [F. Nowicki], Wotyń, s. 14; SGKP, t. 14, s. 909; Wołyniak [Giżycki], Zniesione, s. 171-172 (gdzie na 1761 rok datowana oblata fundacji); Sobieraj, Fundatorzy, s. 199 (z datą 1760/1761); SGKP, t. 14, s. 903-904 zawiera pozbawioną daty wiadomość, że bernardyni wznieśli swój kościół na placu danym przez Augusta III. Po tym, jak kościół spłonął w pożarze, nabożeństwo przez długi czas odprawiano w reflektarzu klasztoru, a w 1820 roku rozpoczęto budowę murowanej świątyni, którą ukończono w 1842 roku.

${ }^{100}$ Statua, s. [681] (bez daty); Stan, k. 25; SGKP, t. 14, s. 904, 909; Wołyniak [Giżycki], Zniesione, s. 209.

${ }^{101}$ Pałucki, Stan, k. 12, 25-25v; SGKP, t. 14, s. 903, 909-910. Długosz, Z dziejów, s. 13 (z błędną datą 1771).

${ }^{102}$ Encyklopedia wiedzy, s. 805.

${ }^{103}$ Pałucki, Stan, k. 10, 26-26v.

${ }^{104}$ SGKP, t. 14, s. 903. Kościół pojezuicki został rozebrany w 1841 roku.

${ }^{105}$ Długosz, Z dziejów, s. 13-14.

${ }^{106}$ Pałucki, Stan, k. 10v.

${ }^{107}$ W 1775 roku biskup Franciszek Ossoliński, który ,Z powodu sejmów nie mógł spełniać obowiązków pasterskich" (Długosz, Z dziejów, s. 9) dobrał sobie na koadjutora Kacpra Kazimierza Cieciszowskiego (Pałucki, Stan, k. 11). Prawdopodobnie zatem, jeśli odnowienie katedry przypadłoby na okres po 1775 roku dzieło odbudowy byłoby łączone z osobą biskupa Cieciszowskiego. SGKP, t. 14, s. 903 podał informację, że wkrótce po 1768 roku tylko nieco naprawiono katedrę, zaś w 1801 roku całkowicie ją przebudowano kosztem już wtedy biskupa łucko-żytomierskiego Kacpra Cieciszowskiego. W 1805 roku świątynię konsekrowano po wezwaniem św. Zofii.

${ }^{108}$ Długosz, Z dziejów, s. 9.

${ }^{109}$ Długosz, $Z$ dziejów, s. 14. Nastąpiło to jednak dopiero w XIX wieku (SGKP, t. 14, s. 903). 
był murowany kościół katedralny i parafialny założony przez biskupa Ożgę „,na miejscu bardzo dawnego kościoła Panny Maryi”. Drugim - murowany kościół akademicki założony dla misjonarzy jezuickich przez kasztelana kijowskiego Steckiego z przyłączonym funduszem biskupa Radoszewskiego przeznaczonym pierwotnie dla jezuitów chwastowskich. Trzecim - kościół bernardyński fundowany przez starostę żytomierskiego Kajetana Ilińskiego ,za zgodą stanów Rzeczypospolitej”. Świątynia ta była drewniana, ale w 1782 roku ,założono mury kościoła i konwiktu" ${ }^{110}$. W latach osiemdziesiątych XVIII wieku w mieście przybyła jeszcze jedna świątynia łacińska. W 1788 roku z rozporządzenia komisji boni ordinis na przedmieściu Kokryn wzniesiono murowaną kaplicę pod wezwaniem św. Mikołaja na pamiątkę istniejącego tu niegdyś kościoła pod tym samym wezwaniem ${ }^{111}$.

Dwukrotnie po zniszczeniach odbudowywany kościół łaciński w Byszowie. W końcu XVII wieku powrócili do miasta dominikanie ${ }^{112}$, którzy posiadali tu klasztor przed powstaniem Chmielnickiego ${ }^{113}$. W 1711 roku miasto zostało oblężone przez Kozaków Mazepy. Ludność schroniła się na zamku, gdzie znajdował się także kościół. Zamek został zdobyty, a Kozacy wymordowali dużą część ludności, w tym wszystkich księży ${ }^{114}$. W 1729 roku prowincjał dominikanów po raz drugi sprowadził ich do Byszowa. Nie było wówczas kościoła ani klasztoru, więc „poświęcił tylko miejsce, gdzie był kościół i chrustem kazał ogrodzić”, a dominikanie zamieszkali na zamku. Rok później na miejscu dawnego kościoła Franciszek Charlęski wzniósł małą kapliczkę „na sklepie grobowym swych przodków”, a w 1739 roku ,staraniem księdza wikarego Musiałkiewicza” postawiono nowy kościół „z drzewa sosnowego w kostkę oprawionego" "115. W latach 1746-1748 potwierdzono istnienie kościoła. Parafię, która obejmowała 37 osad, prowadzili dominikanie. W 1777 roku należało do niej 217 wiernych $^{116}$. Świątynia, którą wzniesiono w 1739 roku została konsekrowana 20 XI 1751 roku przez biskupa kijowskiego Ignacego Sołtyka pod wezwaniem Matki Boskiej Różańcowej ${ }^{117}$. Została ona odnotowana wśród kościołów parafialnych diecezji kijowskiej w 1767 roku. Prawo patronatu należało wtedy do starosty Charlęskiego, zaś parafia znajdowała

${ }^{110}$ Pałucki, Stan, k. 16v.

${ }^{111}$ SGKP, t. 14, s. 904.

${ }^{112}$ SGKP, t. 1, s. 516; Wołyniak [Giżycki], Zniesione, s. 174.

${ }^{113}$ SGKP, t. 1, s. 516; Wołyniak [Giżycki], Z przeszłości powiatu wołkowyskiego, Kraków 1905, s. 89; [Giżycki], Spis ważniejszych, s. 403; Wołyniak [Giżycki], Zniesione, s. 174. Stan, k. 18 podaje, że w 1644 roku fundowano w Byszowie kościół z księdzem ex clero, a dominikanie pojawili się dopiero w 1739 roku.

${ }^{114}$ SGKP, t. 1, s. 516-517; Wołyniak [Giżycki], Zniesione, s. 174.

${ }^{115}$ SGKP, t. 1, s. 517; Wołyniak [Giżycki], Zniesione, s. 174. Stan, k. 18 datuje na 1739 rok sprowadzenia za zgodą biskupa dominikanów „, dodaniem cura animarum” po zniszczeniu dawnej parafii. Wydaje się jednak, że zakonnicy byli w mieście już wcześniej, a w 1739 roku biskup powierzył im zapewne parafię po wzniesieniu nowego kościoła.

${ }^{116}$ Defensa Biskupstwa, s. 144; Heleniusz [Iwanowski], Wspomnienia, s. 267, 270, 297;

Wołyniak [Giżycki], Zniesione, s. 174.

${ }^{117}$ SGKP, t. 1, s. 517; Wołyniak [Giżycki], Zniesione, s. 174. 
się pod zarządem dominikanów ${ }^{118}$. Zapewne ten sam drewniany kościół dominikański z cura animarum ,na miejscu starodawnym” wspomina opis z 1782 ro$\mathrm{ku}^{119}$. Przy konwencie istniała wówczas także szkółka bez funduszu. W 1787 roku zbudowano nowy większy klasztor, który został wystawiony przez księdza Anzelma Piątkowskiego. W 1793 roku w klasztorze było trzech mnichów ${ }^{120}$.

Słabo naświetlona przez źródła, a przez to trudna do omówienia jest kwestia istnienia w pierwszej połowie XVIII wieku świątyni w Czarnobylu. Bez wątpienia już w pierwszej połowie XVII wieku działali tu dominikanie, których klasztor fundował najpóźniej w 1626 roku Łukasz Sapieha z żoną Zofią Kmicianką ${ }^{121}$. Kościół i klasztor zapewne uległy dewastacji w 1649 roku, gdy Kozacy wymordowali zakonników ${ }^{122}$, ale mógł zostać odbudowany już wkrótce, zwłaszcza, że Czarnobyl na pewno obronił się przed najeźdźcami także w $1651 \mathrm{roku}^{123}$. Nie znamy losów tutejszej świątyni w najtrudniejszym okresie drugiej połowy lat pięćdziesiątych XVII wieku, gdy wojska kozackie i moskiewskie zajęły prawie całą Litwę i dotarły do Wisły. Wydaje się jednak prawdopodobne, że z racji położenia w północnej części diecezji Czarnobyl mógł uniknąć zniszczeń związanych z wojnami tureckimi z lat siedemdziesiątych XVII wieku. Właśnie na koniec lat siedemdziesiątych, oraz na lata osiemdziesiąte XVII wieku możemy datować ustanowienie w Czarnobylu parafii ${ }^{124}$. Także w tym okresie (w 1682-1683 roku) występuje dominikanin Jacek Trzaska, który zapewne był przeorem klasztoru czarnobylskiego ${ }^{125}$. W każdym razie w 1709 roku prawdopodobnie klasztor już ponownie istniał ${ }^{126}$. W czasie wizytacji $\mathrm{z}$ lat $1746-1748$ potwierdzono istnienie kościoła i klasztoru dominikanów. Zakonnicy zarządzali parafią, do której należa-

${ }^{118}$ Statua, s. [680].

${ }^{119}$ Pałucki, Stan, k. 18.

${ }^{120}$ SGKP, t. 1, s. 517; Wołyniak [Giżycki], Zniesione, s. 174.

${ }^{121}$ SGKP, t. 1, s. 752-754; Sapiehowie. Materjaty historyczno-genealogiczne i majątkowe, t. 1, Petersburg 1890, s. 193, 197-198; F. Rawita-Gawroński, Studya i szkice historyczne. Serya 1, Lwów 1903, s. 44, 46, 47; Wołyniak [Giżycki], Z przeszłości, s. 89; [Giżycki], Spis ważniejszych, s. 403; Wołyniak [Giżycki], Zniesione, s. 177.

${ }^{122}$ Wołyniak [Giżycki], Zniesione, s. 178.

${ }^{123}$ SGKP, t. 1, s. 752.

${ }^{124}$ SGKP, t. 1, s. 754 podaje, że parafię w Czarnobylu wydzielił dopiero biskup Załuski. Pozornie mogłoby to oznaczać, że powstała ona najwcześniej w 1759 roku (w tym roku biskupem kijowskim został Józef Andrzej Załuski). Tymczasem powinniśmy pamiętać, że w latach 1679-1691 biskupem kijowskim był Chryzostom Załuski. Działał on w czasach zupełnego upadku diecezji, ale podejmował także próby przywracania jej struktur. W jego czasach wznowiono na przykład prowadzenie akt kapituły kijowskiej. Próbował on także normalizować sytuację na terenie diecezji. Wziął od Piotra Wielkiego 20 tysięcy złotych za utracone na rzecz Moskwy dobra biskupie, co miało zapewne stabilizować sytuację na pogranicznych i wciąż niespokojnych terenach Ukrainy. Zob.: Pałucki, Stan, k. 8. Możemy zatem uznać za prawdopodobne ustanowienie przez niego parafii przy istniejącej już wtedy i stabilnej świątyni dominikańskiej w Czarnobylu. Jeśli ta hipoteza jest słuszna, to początki parafii czarnobylskiej sięgałyby lat osiemdziesiątych XVII wieku.

${ }^{125}$ Wołyniak [Giżycki], Zniesione, s. 184.

${ }^{126}$ Wołyniak [Giżycki], Zniesione, s. 178. 
ły trzy miasteczka i 20 wsi $^{127}$. Około połowy XVIII wieku świątynia spłonęła od uderzenia pioruna, ale szybko została odnowiona. W 1759 roku kościół został poświęcony przez przeora konwentu czarnobylskiego księdza Franciszka Murziewicza za indultem biskupa kijowskiego Józefa Załuskiego. Przy świątyni pod wezwaniem Wniebowzięcia NMP był wtedy klasztor, w którym zgodnie z zapisem funduszu powinno być 12 zakonników, ale „dla małości prowincji” było tylko dwóch ${ }^{128}$. W 1767 roku wspomniano istnienie kościoła czarnobylskiego jako świątyni parafialnej. Patronat tutejszej parafii, znajdującej się pod zarządem dominikanów, należał do starosty Chodkiewicza ${ }^{129}$. W 1777 roku parafia czarnobylska miała 314 wiernych ${ }^{130}$. W 1782 roku odnotowano istnienie drewnianego kościoła dominikanów z cura animarum ,fundowanego hojnie na miejscu starodawnym" przez Sapiehów ${ }^{131}$.

Siedzibą innego klasztoru dominikańskiego działającego na terenie diecezji kijowskiej był Lubar. Pierwotnej fundacji kościoła i klasztoru dokonał w 1634 roku właściciel miasta, wojewoda ruski Stanisław Lubomirski. W czasie powstania Chmielnickiego Lubar odparł ataki Kozaków, ale w trakcie walk klasztor uległ zniszczeniu ${ }^{132}$. Lubarski kościół został wymieniony wśród świątyń obdarowanych przez biskupa Samuela Ożgę podczas jego wizytacji133. Oznacza to, że kościół istniał już około 1724 roku. Przekaz z lat 1746-1748 mówi o istnieniu kościoła dominikanów będącego jednocześnie kościołem parafialnym. Parafia obejmowała wtedy Lubar i 36 wsi $^{134}$. W 1752 roku książę Franciszek Ferdynand Lubomirski zbudował nowy, murowany kościół i klasztor dominikanów w Lubarze ${ }^{135}$. Odnowienie kościoła po zniszczeniach źródła przypisują zresztą nie Franciszkowi Lubomirskiemu, ale miecznikowi koronnemu Antoniemu Lubomirskiemu ${ }^{136}$, który

${ }^{127}$ Defensa Biskupstwa, s. 148-148v; Heleniusz [Iwanowski], Wspomnienia, s. 271, 297.

${ }^{128}$ SGKP, t. 1, s. 753; Wołyniak [Giżycki], Zniesione, s. 178.

129 Statua, s. [680].

${ }^{130}$ Wołyniak [Giżycki], Zniesione, s. 178.

${ }^{131}$ Pałucki, Stan, k. 18v. Kościół w Czarnobylu był w XVIII wieku zaliczany do licznych fundacji dokonanych przez Sapiehów. Został wymieniony wśród fundacji tego rodu na kazaniu pogrzebowym Józefa Sapiehy w 1744 roku. Zob.: Sapiehowie, t. 3, Petersburg 1894, s. 139-140. Być może zatem do grona fundatorów, czy też odnowicieli czarnobylskiej świątyni zaliczano innych, obok Łukasza Sapiehy, członków tego rodu.

${ }^{132}$ SGKP, t. 5, s. 375; J. Włast [J. Dunin-Karwicki], Opowiadania historyczne z dziejów okolicy Stuczy i jej dopływów, Kraków 1897, s. 41, 43; Wołyniak [Giżycki], Z przeszłości, s. 93;

[Giżycki], Spis ważniejszych, s. 404; A. Boniecki, A. Reiski, Herbarz Polski, cz. 1: Wiadomości historyczno-genealogiczne o rodach szlacheckich, wyd. A. Boniecki, t. 15, Warszawa 1915, s. 62; Wołyniak [Giżycki], Zniesione, s. 181-182.

${ }^{133}$ Defensa Biskupstwa, s. 111.

${ }^{134}$ Defensa Biskupstwa, s. 138-139; Heleniusz [Iwanowski], Wspomnienia, s. 266, 268, 297.

135 SGKP, t. 5, s. 375; Włast [Dunin-Karwicki], Opowiadania, s. 43;

Wołyniak [Giżycki], Zniesione, s. 181-182. Franciszek Ferdynand Lubomirski, starosta biecki, miecznik wielki koronny i chorąży wielki koronny. Zob.: Urzędnicy centralni $i$ nadworni Polski XIV-XVIII wieku. Spisy, opr. K. Chłapowski, S. Ciara, Ł. Kądziela, T. Nowakowski, E. Opaliński, G. Rutkowska, T. Zielińska, pod red. A. Gąsiorowskiego, Kórnik 1992, s. 91, nr 494.

${ }^{136}$ Pałucki, Stan, k. 16v. 
pełnił swój urząd w latach 1754-1761, lecz działał także aktywnie w latach siedemdziesiątych i osiemdziesiątych XVIII wieku ${ }^{137}$. Wiele wskazuje na to, że Lubomirscy dbali o klasztor lubarski jako o rodzinną fundację i gdy popadał w ruinę pamiętali o jego odbudowie. Jednocześnie możemy przyjąć, że w lokalnej tradycji mylono później różnych członków tej rodziny ${ }^{138}$. Jednocześnie nie ulega wątpliwości, że wzniesienie murowanych budynków wiązało się ze wzrostem znaczenia tutejszej świątyni. W 1754 roku biskup Kajetan Sołtyk sprowadził do niej cudowny obraz z Hryniowiec ${ }^{139}$. 4 VIII 1765 roku kościół został konsekrowany w obecności fundatora miecznika koronnego Franciszka Lubomirskiego przez biskupa kijowskiego i czernihowskiego Józefa Andrzeja Załuskiego pod wezwaniem św. Michała Archanioła i św. Jana Nepomucena ${ }^{140}$. W 1767 roku odnotowano istnienie parafialnego kościoła lubarskiego, którego patronem był miecznik koronny Lubomirski. Parafia znajdowała się pod zarządem dominikanów ${ }^{141}$. Opisana sytuacja nie uległa zmianie w ciągu następnych 15 lat. W 1782 roku istniał murowany kościół dominikanów posiadający cura animarum, fundowany „,na miejscu starodawnego" przez księcia Antoniego Lubomirskiego ${ }^{142}$. Dominikanie prowadzili przy klasztorze szkołę. Musiała być to placówka na tyle znacząca, że w 1796 roku powierzono im prowadzenie opartej na niej szkoły powiatowej ${ }^{143}$.

Co najmniej od 1714 roku funkcjonował kościół karmelitów bosych w Berdyczowie. Po rzeziach kozackich w latach 1648-1649 oraz 1653 i zniszczeniu kościoła i klasztoru zakonnicy powrócili do miasta już w 1663 roku. Od 1684 roku borykali się jednak z niechęcią ze strony krewnych fundatora tutejszego klasztoru Janusza Tyszkiewicza. Właściciele miasta dążyli wręcz do usunięcia zakonników i należy się spodziewać, że świątynia nie funkcjonowała w tym okresie w sposób normalny. 19 III 1684 roku żołnierze Tyszkiewiczów złupili kościół i klasztor, zaś dwa lata później dragoni wygnali karmelitów z miasta. Rozpoczął się wtedy długotrwały proces sądowy. Ostatecznie w 1717 roku karmelici wygrali proces uzyskując prawne potwierdzenie fundacji klasztoru berdyczowskiego (ale byli już na pewno w mieście w 1714 roku). Początkowo karmelici mieszkali w drewnianej chatce i sami pracowali, by się utrzymać. Wkrótce jednak powstał mały drewniany klasztor i jednocześnie rozpoczęto odbudowę kościoła (zwanego

${ }^{137}$ Boniecki, Reiski, Herbarz Polski, t. 15, s. 66-67. Nominowany na urząd 6 VII 1754 roku, zrezygnował przed 21 VII 1761 roku. Zob.: Urzędnicy centralni i nadworni, s. 91, nr 493.

${ }^{138}$ Odbudowa świątyni przed 1744 rokiem przez Antoniego Lubomirskiego jest niemożliwa, bo działał on zbyt późno. Wyjaśnieniem zapisu źródłowego jest założenie, że tradycja pomieszała dwóch mieczników koronnych pochodzących z rodu Lubomirskich: Antoniego Benedykta, pełniącego urząd w latach 1754-1761 oraz Aleksandra Jakuba, sprawującego ten sam urząd od 18 VI 1728 do lipca 1748 roku (Urzędnicy centralni i nadworni, s. 91, nr 491, 493).

${ }^{139}$ SGKP, t. 5, s. 375.

${ }^{140}$ Statua, s. [679, 682]; SGKP, t. 5, s. 375; Włast [Dunin-Karwicki], Opowiadania, s. 43.

${ }^{141}$ Statua, s. [679, 680].

${ }^{142}$ Pałucki, Stan, k. 16v.

${ }^{143}$ K. Mrozowska, Uniwersytet Wileński i jego szkoty w latach 1795-1803, (w:) Studia z dziejów Uniwersytetu Wileńskiego 1579-1979, red. K. Mrozowska, Kraków-Warszawa 1979, „Zeszyty Naukowe Uniwersytetu Jagiellońskiego", nr 554, Prace historyczne, z. 64, s. 72. 
potem dolnym), która trwała do 1737 roku. Po zakończeniu odbudowy świątyni karmelici rozpoczęli w 1739 roku wznoszenie nowego, tak zwanego górnego, kościoła, który był budowany na fundamentach kościoła dolnego ${ }^{144}$. Kościół w Berdyczowie został wspomniany wśród świątyń obdarowanych przez biskupa Samuela Ożgę w czasie jego wizytacji w latach dwudziestych XVIII wieku ${ }^{145}$. Oznacza to, że funkcjonował już niewątpliwie około 1724 roku. Dokładnie o sytuacji świątyń berdyczowskich informuje nas opis sporządzony w czasie wizytacji z lat 1746-1748. Mówi on o braku świątyni parafialnej oraz o krzyżu stojącym na dawnym jej miejscu. Jednocześnie jednak funkcjonowała parafia, bowiem cura animarum należała do karmelitów bosych. Wiemy też, że do parafii oprócz Berdyczowa należały 23 wsie ${ }^{146} .9$ VI 1751 roku biskup koadjutor kijowski Kajetan Sołtyk wizytował parafię berdyczowską, zaś w 1753 lub 1754 roku konsekrował tutejszy kościół karmelitów ${ }^{147}$. Wkrótce potem nastąpiły zmiany struktury administracyjnej Kościoła łacińskiego. W 1759 roku koniuszyna litewska Barbara z Zawiszów Radziwiłłowa fundowała „w miejscu starodawnego” kościół parafialny ${ }^{148}$, którego powstanie powinno oznaczać zmianę statusu świątyni karmelitów na kościół przyklasztorny, bez praw parafialnych. Tymczasem do 1767 roku sytuacja nie uległa zapewne zmianie. Opis pochodzący z tego roku informuje bowiem o braku kościoła parafialnego w Berdyczowie. Należy przyjąć, że jego budowa nie została jeszcze wówczas dokończona. Prawo patronatu należało do starosty rzeczyckiego Radziwiłła, a parafia była zarządzana przez karmelitów bosych. Prepozytem berdyczowskim był wówczas archidiakon czernihowski Józef Rabczewski ${ }^{149}$. Przeniesienie siedziby parafii do nowego kościoła nastąpiło zatem po 1767 roku. W 1782 roku odnotowano już w mieście dwa kościoły: murowany kościół karmelitów bosych fundacji wojewody kijowskiego Janusza Tyszkiewicza, przy którym istniały ,porządna forteczka i drukarnia”, oraz „nowo założony” drewniany kościół parafialny fundowany przez Barbarę Radziwiłłową „na miejscu starodawnego", którego posiadała też ona prawo patronatu ${ }^{150}$.

Zapewne początków lat dwudziestych XVIII wieku sięgają początki świątyni w Luczynie. Obecność misjonarzy jezuickich podlegających rezydencji owruckiej jest tu potwierdzona w latach 1721-1722 oraz od 1734 roku $^{151}$. W okresie wizytacji przeprowadzonej w latach 1746-1748 potwierdzono istnienie tutejszej

${ }^{144}$ SGKP, t. 1, s. 135-136; Wołyniak [Giżycki], Zniesione, s. 202-203; B. J. Wanat, Zakon karmelitów bosych w Polsce. Klasztory karmelitów i karmelitanek bosych w Polsce 1605-1975, Kraków 1979, s. 379-381.

${ }^{145}$ Defensa Biskupstwa, s. 111. Wspomniano także, że fundatorem kościoła karmelitów bosych był Janusz Tyszkiewicz (Tamże, s. 115).

${ }^{146}$ Defensa Biskupstwa, s. 139-140; Heleniusz [Iwanowski], Wspomnienia, s. 267-9, 297.

${ }^{147}$ SGKP, t. 1, s. 136, 138; Wołyniak [Giżycki], Zniesione, s. 203; Wanat, Zakon, s. 381.

${ }^{148}$ SGKP, t. 1, s. 137.

${ }^{149}$ Statua, s. [678-680].

${ }^{150}$ Pałucki, Stan, k. 16v-17. Wiele wskazuje na to, że kościół parafialny został oddany do użytku nie wcześniej niż w 1774 roku. Wskazuje na to zapis mówiący o tym, że kościół ten „przyczynił” biskup Franciszek Ossoliński (Pałucki, Stan, k. 11), który pełnił swój urząd właśnie od 1774 roku.

${ }^{151}$ Encyklopedia wiedzy, s. 394. 
kaplicy, która należała do działających w okolicy jezuitów ${ }^{152}$. Od 1632 roku Łuczyn wraz z Holaczkami i Fedorówką należał do jezuickiego kolegium chwastowskiego ${ }^{153}$. Już jednak w 1644 roku przeniesiono je do Kijowa, a po wojnach z XVII wieku ostatecznie znalazło ono siedzibę w Owruczu. W 1678 roku połowa Łuczyna należała do rezydencji owruckiej, połowa do kolegium kijowskiego. Sam Łuczyn był jednak wtedy opuszczony. Dopiero w XVIII wieku powstała tu świątynia określana mianem małego kościoła lub kaplicy. Funkcjonowała ona do kasaty jezuitów w 1773 roku $^{154}$. Tutejsza kaplica jezuitów ostatni raz została odnotowana wśród świątyń diecezji kijowskiej w 1767 roku ${ }^{155}$.

W 1723 roku na miejscu starego, zniszczonego kościoła w Chwastowie biskup kijowski Samuel Ożga fundował, uposażył, wzniósł i wyposażył w aparat liturgiczny nową świątynię pod wezwaniem NMP Bolesnej. Pełniła ona odtąd rolę katedry aż do momentu przeniesienia się biskupów kijowskich do Żytomierza. Kościół został zbudowany szybko, skoro już w 1724 roku był wizytowany przez biskupa. W 1727 roku parafia obejmowała 24 miejscowości ${ }^{156}$. W latach 1746-1748 zostało potwierdzone istnienie tutejszego kościoła, a do parafii, poza samym Chwastowem, wciąż jeszcze należały 23 wsie. Znaczenie Chwastowa jako ośrodka kościelnego podkreślał fakt, że był on stolicą dekanatu ${ }^{157}$. W okresie 1746-1749 funkcjonowała w mieście stacja misyjna jezuitów nawiązująca do tradycji tutejszego ośrodka jezuickiego z pierwszej połowy XVII wieku ${ }^{158}$. Nie zdołała ona przetrwać kolejnych burzliwych wydarzeń, które spadły na Chwastów. W latach 1749 i 1750 miasto było niszczone przez hajdamaków ${ }^{159}$. Być może w czasie tych zniszczeń ucierpiał także kościół parafialny, wiemy bowiem, że w 1751 roku biskup Ignacy Kajetan Sołtyk dokonał konsekracji nowo wzniesionej świątyni ${ }^{160}$. Została ona odnotowana $\mathrm{w}$ spisie kościołów diecezji kijowskiej w 1767 roku. Prawo patronatu tutejszej parafii należało wówczas do biskupa, plebanem był kanonik honorowy Marcin Rybiński, a chwastowskim dziekanem terenowym Józef Bogucki ${ }^{161}$. W 1768 roku kościół wraz z miastem został ponownie zniszczony, zaś mieszkańcy wymordowani przez Kozaków ${ }^{162}$. Zginęło wtedy 700

${ }^{152}$ Defensa Biskupstwa, s. 149v (w ramach dekanatu chwastowskiego); Heleniusz [Iwanowski], Wspomnienia, s. 270-271 (autor poinformował, że Łuczyn należał do parafii chodorkowskiej, o czym nie napisał Orłowski).

${ }^{153}$ SGKP, t. 5, s. 799; Encyklopedia wiedzy, s. 394.

${ }^{154}$ Encyklopedia wiedzy, s. 394. SGKP, t. 5, s. 801 podaje, że w Łuczynie istniała ecclesia seu capella, ale nie informuje kiedy.

${ }^{155}$ Statua, s. [680].

${ }^{156}$ Defensa Biskupstwa, s. 111, 163; SGKP, t. 1, s. 663; F. Sznarbachowski, Historyczny rys Fastowa, Warszawa 1904, s. 61.

${ }^{157}$ Defensa Biskupstwa, s. 143; Rulikowski, Opis, s. 76, przypis 2 (wbrew opisowi Orłowskiego podano w okręgu parafialnym liczbę 22 wsi poza Chwastowem); Heleniusz [Iwanowski], Wspomnienia, s. 267, 297.

${ }^{158}$ Encyklopedia wiedzy, s. 152.

${ }^{159}$ SGKP, t. 1, s. 663; Sznarbachowski, Historyczny rys, s. 62.

${ }^{160}$ Rulikowski, Opis, s. 76, przypis 2.

${ }^{161}$ Statua, s. [679].

${ }^{162}$ SGKP, t. 1, s. 663-664; Rulikowski, Opis, s. 75-77; Sznarbachowski, Historyczny rys, s. 63. 
katolików obrządku łacińskiego ${ }^{163}$. W latach 1774-1783 trwała odbudowa mia$\mathrm{sta}^{164}$. Podniesiono także z ruin świątynię, skoro w 1782 roku odnotowano istnienie drewnianego kościoła parafialnego, fundowanego „na miejscu starodawnego" przez biskupa Ożgę i kapitułę (biskup posiadał prawo patronatu tej świątyni) ${ }^{165}$. Kościół był jednak zniszczony (być może dokonano tylko niezbędnych napraw), a problemy z odprawianiem w nim nabożeństwa spowodowały konieczność budowy nowej świątyni w innym miejscu. Ostatecznie nowy drewniany kościół został wzniesiony w 1791 roku przez biskupa Cieciszowskiego, a benedykowany dwa lata później przez Kazimierza Ostrowskiego ${ }^{166}$. W XVIII wieku Chwastów jako ośrodek kościelny nie odzyskał już takiego znaczenia, jakie posiadał $\mathrm{w}$ pierwszej połowie XVII wieku. Nie powiodła się próba powrotu do miasta jezuitów, zaś tutejsi bernardyni znaleźli sobie siedzibę w Żytomierzu ${ }^{167}$.

Kościół w Babiczach został na nowo fundowany także przez biskupa Ożgę z kapitułą. Biskup ponadto uposażył kościół i zapewnił mu sprzęt liturgiczny ${ }^{168}$. Miało to miejsce nie wcześniej niż w 1722 roku, gdyż biskup w tym właśnie roku objął swój urząd ${ }^{169}$, a z dużym prawdopodobieństwem możemy przyjąć, że fundacja nastąpiła w latach 1723-1724, gdy podjęto energiczne działania zmierzające do odbudowy struktur terytorialnych diecezji. Fundacja biskupia w tym miejscu nie była przypadkowa. Babicze, leżące $\mathrm{w}$ powiecie mozyrskim województwa mińskiego (a więc na Litwie), zostały nadane biskupom kijowskim przez Wiśniowieckich i stanowiły ich dobra stołowe ${ }^{170}$. Kościół istniał w latach 1746-1748, lecz nie było przy nim księdza i nie miał wydzielonej parafii. Sugerowano, że przyczyną takiego stanu rzeczy jest fakt, że Babicze zostały sprzedane przez biskupa wraz z prawem patronatu ${ }^{171}$. Także w 1767 roku, chociaż Babicze znalazły się w spisie kościołów parafialnych diecezji kijowskiej, zapewne tutejsza parafia nie funkcjonowała normalnie. Nie odnotowano kto był posiadaczem jej prawa patronatu, ani obsady plebańskiej. Pojawiła się natomiast wiadomość, że była to parafia sporna z diecezją wileńską ${ }^{172}$. Świątynia babicka rzeczywiście od lat czterdziestych XVIII wieku pojawia się w wykazach kościołów diecezji wileńskiej ${ }^{173}$. W 1782 roku zanotowano, że „w niedawnych czasach”, po sprzedaniu przez kapi-

${ }^{163}$ Pałucki, Stan, k. 25v.

${ }^{164}$ Sznarbachowski, Historyczny rys, s. 71.

${ }^{165}$ Pałucki, Stan, k. 17.

${ }^{166}$ SGKP, t. 1, s. 664; Rulikowski, Opis, s. 76, przypis 2; Sznarbachowski, Historyczny rys, s. 74.

${ }^{167}$ Rulikowski, Opis, s. 71.

${ }^{168}$ Defensa Biskupstwa, s. 111; Pałucki, Stan, k. 19.

${ }^{169}$ Pałucki, Stan, k. 9.

${ }^{170}$ Pałucki, Stan, k. 3v, 16; Heleniusz [Iwanowski], Wspomnienia, s. 272.

${ }^{171}$ Defensa Biskupstwa, s. 149-149v; Heleniusz [Iwanowski], Wspomnienia, s. 267, 272, 297.

${ }^{172}$ Statua, s. [680].

${ }^{173}$ Litak, Kościół łaciński, s. 308. 
tułę kijowską dóbr Babicze Oskierce, kościół został przez niego porzucony i zdemolowany ${ }^{174}$.

Prawdopodobnie w tym samym czasie, lub nawet nieco wcześniej niż kościoły w Chwastowie i Babiczach powstał drewniany kościół w Cudnowie. Świątynię wzniesiono „na grobach chrześcijan pomordowanych przez Tatarów” kosztem księcia Pawła Karola Lubartowicza i jego żony Anny z Lubomirskich, małżonków Sanguszków ${ }^{175}$. Kościół cudnowski został wspomniany wśród kościołów wizytowanych i obdarowanych przez biskupa Samuela Ożgę ${ }^{176}$, co prowadzi do wniosku, że istniał już w latach 1723-1724. W czasie wizytacji z lat 1746-1748 odnotowano już istnienie tutejszego kościoła, a w skład parafii poza samym Cudnowem wchodziło 46 wsi $^{177}$. W 1747 roku w efekcie zabiegów oficjała i dziekana kapituły kijowskiej H. Antoniego Gorczyńskiego sukcesor fundatorów Janusz Aleksander Sanguszko zrzekł się w imieniu swoim i następców prawa patronatu parafii cudnowskiej. Tutejsze beneficjum wraz z wsią Serbinówką i jurysdykcja kościelną odstąpił na rzecz kapituły kijowskiej. Kapituła miała wejść w posiadanie beneficjum salvo moderno possesore, po śmierci ówczesnego proboszcza cudnowskiego i zasławskiego księdza Michała Górskiego. Przejmując kościół w Cudnowie kapituła zobowiązała się utrzymywać przy nim stale dwóch kapłanów - komendarza i wikariusza. Zapis Janusza Sanguszki zrealizowano po śmierci księdza Górskiego i wprowadzony jego treścią stan prawny przetrwał aż do 1842 roku ${ }^{178}$. M. Pałucki podał informacje na temat przyczyn, dla których kapituła kijowska zabiegała o parafię cudnowską. Opisując zasługi biskupa Kajetana Sołtyka dla diecezji kijowskiej zapisał, że podźwignął on kapitułę przez inkorporację beneficjum cudnowskiego, które posiadało wieś Sorbinówkę. Było to ważne dla kapituły po tym, jak utraciła ona swoje dobra funduszowe ${ }^{179}$. W 1760 roku sufragan kijowski, oficjał generalny kijowski i dziekan kapituły Antoni (Adam) Gorczyński zbudował w Cudnowie na miejscu drewnianego nowy murowany kościół parafialny pod wezwaniem Znalezienia Krzyża Świętego z dwiema kaplicami. Kościół ten został poświęcony w 1762 roku przez biskupa kijowskiego i czernihowskiego Józefa Andrzeja Załuskiego ${ }^{180}$. Odnotowano jego istnienie w 1767 roku. Prawo patronatu tutejszej parafii należało wówczas do ordynata ostrogskiego, komendarzem był ksiądz Antoni Stefański, a wikariuszem Mikołaj Remczyński ${ }^{181}$.

${ }^{174}$ Pałucki, Stan, k. 19. W XIX wieku nie potrafiono dokładnie zlokalizować Babicz, o czym świadczy ich błędne utożsamienie z miejscowościami o podobnych nazwach, położonymi jednak nie na północ od Prypeci, lecz w rejonie Żytomierza (SGKP, t. 15, dopełnienia, Warszawa 1900, s. 59).

${ }^{175}$ SGKP, t. 1, s. 714. Paweł Karol Sanguszko, którego drugą żoną była Marianna z Lubomirskich zmarł w 1759 roku. Zob.: T. Żychliński, Złota księga szlachty polskiej, Rocznik V, Poznań 1883, s. 296-297.

${ }^{176}$ Defensa Biskupstwa, s. 111.

${ }^{177}$ Defensa Biskupstwa, s. 137-138; Heleniusz [Iwanowski], Wspomnienia, s. 266, 268, 297.

${ }^{178}$ SGKP, t. 1, s. 714.

${ }^{179}$ Pałucki, Stan, k. 10.

${ }^{180}$ Statua, s. [679, 681]; SGKP, t. 1, s. 714.

${ }^{181}$ Statua, s. [679]. 
W tym samym czasie, w którym powstał kościół parafialny, około 1760 roku, doszło do zbiorowej fundacji kościoła i klasztoru bernardynów w Cudnowie. Fundatorami byli marszałek nadworny litewski Janusz Sanguszko, chorąży krzemieniecki Przyłuski i inni. Fundacja została zrealizowana najpóźniej w 1769 roku, zaś kościół bernardynów pod wezwaniem św. Jana Nepomucena został wzniesiony ze składek $^{182}$. W efekcie w mieście powstała druga świątynia łacińska. Istnienie kościoła w Cudnowie zostało potwierdzone także w 1782 roku $^{183}$.

W latach 1723-1724 istniał już także kościół w Korosteszowie, wymieniony wśród świątyń wizytowanych i obdarowanych przez biskupa Samuela Ożgę ${ }^{184}$. W latach 1746-1748 wymieniono tutejszy kościół parafialny, a do parafii należało 59 miejscowości ${ }^{185}$. Odbudowa świątyni jest trudna do precyzyjnego umiejscowienia w czasie, ale nastąpiła nie wcześniej niż w drugiej dekadzie XVIII wieku. Miejscowość została bowiem na długi czas opanowana przez Kozaków ${ }^{186}$ i zupełnie wyludniona w okresie wojen, zaś powolny napływ osadników nastąpił tu dopiero po stłumieniu buntu Paleja. Na odbudowę tutejszego kościoła w początku lat dwudziestych XVIII wieku może wskazywać podana przez źródła osoba fundatorki świątyni, którą miała być stolnikowa kijowska Domicella Olizarowa Wołczkiewiczowa ${ }^{187}$. Jedynym stolnikiem kijowskim z rodziny Olizarów Wołczkiewiczów był Józef Olizar Wołczkiewicz, który sprawował swój urząd od marca 1720 roku do 1742 roku $^{188}$. Zapewne właśnie w pierwszych latach tego okresu nastąpiła fundacja nowej świątyni w Korosteszowie. 6 II 1751 roku parafia była wizytowana przez biskupa Sołtyka ${ }^{189}$. W 1767 roku odnotowano tutejszy kościół w spisie kościołów parafialnych diecezji kijowskiej. Prawo patronatu należało wtedy do Olizarów, a plebanem był kanonik honorowy Herbacz ${ }^{190}$. Wacław Herbacz występował także wśród honorowych kanoników kapituły kijowskiej w 1782 roku jako dawny pleban korosteszowski ${ }^{191}$. W tym samym roku odnotowano w Korosteszowie drewniany kościół parafialny fundowany „,na miejscu starodawnego" przez stolnikową kijowską Domicellę Olizarową Wołczkowiczową. Prawo patronatu kościoła należało do podczaszego litewskiego Olizara ${ }^{192}$. Wkrót-

${ }^{182}$ Wołyniak [Giżycki], Zniesione, s. 170-171; Sobieraj, Fundatorzy, s. 169. SGKP, t. 1, s. 714 podaje, że budowę kościoła i klasztoru rozpoczęto już w pierwszej połowie XVIII wieku, a ukończono dopiero w 1820 roku.

183 Pałucki, Stan, k. 19v.

${ }^{184}$ Defensa Biskupstwa, s. 111.

${ }^{185}$ Defensa Biskupstwa, s. 141-142; Heleniusz [Iwanowski], Wspomnienia, s. 267, 269, 297.

${ }^{186}$ Polski Słownik Biograficzny (dalej: PSB), t. 23, Wrocław-Warszawa-Kraków-Gdańsk 1978, s. 811 .

${ }^{187}$ Pałucki, Stan, k. 17.

${ }^{188}$ Urzędnicy województw kijowskiego i czernihowskiego, s. 64, nr 371.

${ }^{189}$ SGKP, t. 4, s. 419.

${ }^{190}$ Statua, s. [679].

${ }^{191}$ Pałucki, Stan, k. 12v.

${ }^{192}$ Pałucki, Stan, k. 17. Niewątpliwie chodzi o Filipa Nereusza Olizara Wołczkiewicza, szambelana JKM, który został nominowany na podczaszego litewskiego 30 VIII 1780 roku. Zob. Urzędnicy centralni i dostojnicy Wielkiego Księstwa Litewskiego XIV-XVIII wieku. Spisy, opr. H. Lulewicz, A. Rachuba, Kórnik 1994, s. 146, nr 1124. 
ce w miejsce drewnianego kościoła Józef Kalasanty Olizar Wołczkiewicz wzniósł świątynię murowaną ${ }^{193}$. W 1794 roku plebanem w Korosteszowie był ksiądz Kulikowski. Dwa lata później Filip Nereusz Olizar dokonał zamiany funduszowej z kościołem. Kościół otrzymał więcej gruntu, a patron jednocześnie zobowiązywał się zbudować dom dla wikarego i organisty oraz osobny dom na szkołę parafialną, a także szpital. Proboszcz korosteszowski miał odtąd utrzymywać organistę i kantora zdolnego do prowadzenia początkowej edukacji. Posiadamy informację, że na miejscu drewnianej świątyni zbudowano murowany kościół parafialny ${ }^{194}$. Informacja ta jest pozbawiona daty, ale zapewne odnosi się do sytuacji po zamianie funduszowej. Należy ją zatem datować na okres po 1796 roku.

W 1742 roku dziedzic Chodorkowa Franciszek Ksawery Nitosławski fundował w swoim mieście kościół i klasztor dominikanów, którym zapisał wieś Sobolówkę i 25 tysięcy złotych zapisu na wsi Jaropołczy. Zakonnicy od momentu sprowadzenia prowadzili tutejszą parafię ${ }^{195}$. Z lat 1746-1748 posiadamy informację o istnieniu w Chodorkowie kościoła i klasztoru dominikanów, którzy prowadzili także parafię obejmującą 35 osad $^{196}$. Kościół został poświęcony (jako parafialny) 17 VI 1753 roku przez koadjutora kijowskiego Kajetana Sołtyka pod wezwaniem św. Stanisława ${ }^{197}$. W latach 1762-1764 właściciel miasta, łowczy brzeski, dziekan i scholastyk kijowski Kajetan Rościszewski (siostrzeniec Franciszka Nitosławskiego) fundował w Chodorkowie kościół i klasztor (pierwotnie hospicjum) kapucynów $^{198}$ (kościół ten został benedykowany przez proboszcza chodorkowskiego, przeora dominikanów księdza Jaworskiego pod wezwaniem św. Kajetana ${ }^{199}$ ). W późniejszym czasie kapucyni chodorkowscy obsługiwali dodatkowo kaplicę w Zarubińcach ${ }^{200}$. W latach sześćdziesiątych XVIII wieku przy kościele dominikanów istniały szpital i szkoła parafialna ${ }^{201}$. W spisie kościołów parafialnych diecezji kijowskiej z 1767 roku odnotowano, że prawo patronatu parafii chodorkowskiej należało do scholastyka kijowskiego Kajetana Rościszewskiego, a samą

${ }^{193}$ PSB, t. 23, s. 811.

${ }^{194}$ SGKP, t. 4, s. 419.

${ }^{195}$ SGKP, t. 1, s. 609; Wołyniak [Giżycki], Z przeszłości, s. 89; [Giżycki], Spis ważniejszych, s. 403; Wołyniak [Giżycki], Zniesione, s. 175, 194. Franciszek Ksawery Nitosławski h. Dołęga łowczy chełmski, starosta sielecki, sędzia grodzki grabowiecki, sędzia grodzki i ziemski kijowski (1743-1749), podwojewoda kijowski (1750-1759), występował już w drugim ćwierćwieczu XVIII stulecia. Zob. K. Niesiecki, Herbarz Polski, wyd. J. N. Bobrowicz, t. 6, Lipsk 1841, s. 571 (zapisany jako Nitostawski); S. Uruski, Rodzina. Herbarz szlachty polskiej, t. 12, Warszawa 1915, s. 160; Urzędnicy województwa betskiego i ziemi chetmskiej XIV-XVIII wieku. Spisy, opr. H. Gmiterek i R. Szczygieł, pod red. A. Gąsiorowskiego, Kórnik 1992, s. 158, nr 1154.

${ }^{196}$ Defensa Biskupstwa, s. 145; Heleniusz [Iwanowski], Wspomnienia, s. 270-271, 297.

${ }^{197}$ SGKP, t. 1, s. 609; Wołyniak [Giżycki], Zniesione, s. 175.

${ }^{198}$ Statua, s. [679, 681] (bez daty); SGKP, t. 1, s. 609 (z datą 1763); Heleniusz [Iwanowski], Wspomnienia, s. 332 (z datą 1762), 452 (z datą 1764); [Giżycki], Spis ważniejszych, s. 415-416 (z datą 1764); Wołyniak [Giżycki], Zniesione, s. 175, 194 (z datą około 1763); Sobieraj, Fundatorzy, s. 236 (z datą 1763).

${ }^{199}$ SGKP, t. 1, s. 609.

${ }^{200}$ Heleniusz [Iwanowski], Wspomnienia, s. 270.

${ }^{201}$ SGKP, t. 1, s. 609. 
parafią zarządzali dominikanie. Wspomniano także, że istniał w mieście klasztor kapucynów fundowany przez Rościszewskiego ${ }^{202}$. Kościół dominikanów został spalony przez hajdamaków w 1768 roku, zginęli wtedy także z ich ręki dwaj tutejsi dominikanie: Rajmund Woroniecki i Gedeon Kozicki ${ }^{203}$. Świątynia została odbudowana dopiero w 1779 roku przez Kajetana Rościszewskiego ${ }^{204}$. W 1782 roku odnotowano istnienie w Chodorkowie dwóch kościołów. Pierwszym był drewniany kościół dominikański, mający cura animarum, fundowany przez sędziego grodzkiego kijowskiego Nitosławskiego z murowanym konwentem. Drugim - fundowany przez Rościszewskiego kościół kapucynów, który także był drewniany, „lecz mury na kościół i konwent podniesione"205.

Trudno określić czas odbudowy kościoła parafialnego w Wielednikach. Świątynia istniejąca tu przed powstaniem Chmielnickiego ${ }^{206}$ uległa zapewne zniszczeniu, lecz już w 1652 roku Potocki wzniósł w mieście drewniany kościół pod wezwaniem Sw. Trójcy ${ }^{207}$. Nie znamy losów odbudowanego kościoła w okresie, w którym Ukraina została opanowana przez wojska kozacko-moskiewskie. Być może uległ wtedy zniszczeniu. Nie wiemy także kiedy go ponownie odbudowano, ale istnienie tutejszej świątyni zostało odnotowane w latach 1746-1748. Funkcjonowała wtedy także wielednicka parafia, która obejmowała 78 osad, a wśród nich także Iskorość, gdzie w pierwszej połowie XVII wieku była osobna parafia ${ }^{208}$. Statua synodu diecezji kijowskiej w spisie parafii z 1767 roku zawierają informację, że patronat parafii wielednickiej należał do Potockich. Tutejszym plebanem był wówczas ksiądz Franciszek Dopniewski, zaś wikariuszami księżą Tchorzewski i Zabłocki ${ }^{209}$. W 1782 roku istniał w Wielednikach drewniany kościół parafialny „fundowany hojnie w miejscu starodawnego" przez Seweryna Potockiego. Spadkobiercy fundatora posiadali prawo patronatu świątyni ${ }^{210}$. Odnotowanie w latach osiemdziesiątych XVIII wieku Seweryna Potockiego jako fundatora świątyni dowodzi, że nie znano wtedy innego, późniejszego fundatora. Czyni to prawdopodobnym uznanie ciągłości tutejszego ośrodka kościelnego od drugiej połowy XVII wieku, kiedy to właśnie żył Seweryn Potocki ${ }^{211}$. M. Pałucki wiedział także o istnieniu akt kościoła wielednickiego. Znajdowały się one jednak, podobnie jak część innych akt konsystorskich, w rękach rodziny jednego z poprzednich biskupów kijowskich ${ }^{212}$.

${ }^{202}$ Statua, s. [679, 680].

${ }^{203}$ Pałucki, Stan, k. 25v; SGKP, t. 1, s. 609. Słownik podaje nazwisko drugiego zabitego jako „Kotowicz”.

${ }^{204}$ SGKP, t. 1, s. 609; Wierzbowski, Szkoły parafjalne, s. 126; Wołyniak [Giżycki], Zniesione, s. 176.

${ }^{205}$ Pałucki, Stan, k. 16v.

${ }^{206}$ Pałucki, Stan, k. 15v; Heleniusz [Iwanowski], Wspomnienia, s. 267, 296.

${ }^{207}$ SGKP, t. 13, s. 311.

${ }^{208}$ Defensa Biskupstwa, s. 147-147v; Heleniusz [Iwanowski], Wspomnienia, s. 267, 271, 297.

${ }^{209}$ Statua, s. [680].

${ }^{210}$ Pałucki, Stan, k. 18.

${ }^{211}$ K. Niesiecki, Herbarz Polski, wyd. J. N. Bobrowicz, t. 7, Lipsk 1841, s. 426.

${ }^{212}$ Stan, k. 12. 
Nie wiemy dokładnie kiedy, ale na pewno przed wizytacją z lat 1746-1748 odbudowano kościół w Białopolu. W czasie wizytacji istniał tu już drewniany kościół parafialny, a do parafii należały $44 \mathrm{wsie}^{213}$. W 1767 roku patronat tutejszej parafii należał do starosty strzałkowskiego Tyszkiewicza. Plebanem był ksiądz Rabczewski, zaś wikariuszem - ksiądz Wilanowski ${ }^{214}$. W 1782 roku odnotowano istnienie drewnianej świątyni fundowanej przez generała Wielkiego Księstwa Litewskiego hrabiego z Łohojska Tyszkiewicza „na miejscu starodawnego kościoła". Fundator sprawował także prawo patronatu świątyni ${ }^{215}$, co wskazuje na fakt, że sama fundacja nie mogła być zbyt odległa w czasie od 1782 roku. Nie możemy jej zatem łączyć z odbudową kościoła przypadającą na pierwszą połowę XVIII wieku.

Podobnie nieznane są nam wydarzenia związane $\mathrm{z}$ odbudową świątyni $\mathrm{w}$ Chabnie. W latach 1746-1748 istniał tu już kościół parafialny, a sama parafia obejmowała 32 osady $^{216}$. Sieć kościołów w północnej części diecezji kijowskiej poniosła, jak się wydaje, stosunkowo najmniejsze straty w czasie wojen z drugiej połowy XVII wieku. Przede wszystkim zaś obszar ten był znacznie spokojniejszy w pierwszej połowie następnego stulecia. Możemy zatem przypuszczać, że tutejsza parafia szybko podniosła się ze zniszczeń. Być może pokrywała się ona nawet ze swoim pierwotnym obszarem (skoro w momencie powstania w 1633 roku obejmowała $32 \mathrm{wsie}^{217}$ ). Informacje pochodzące $\mathrm{z}$ drugiej połowy XVIII wieku wskazują, że także w tym okresie tutejsza parafia funkcjonowała bez większych zakłóceń. W 1767 roku prawo patronatu parafii chabeńskiej należało do kasztelana kijowskiego Steckiego. Plebanem był ksiądz Mikołaj Szweowicz, a przy kościele w Chabnie przebywał także terenowy dziekan owrucki - ksiądz Muszymański $^{218}$. W 1780 roku kościół pod wezwaniem Wniebowzięcia NMP został odbudowany przez chabeńskiego plebana księdza Pawła Wojciechowskiego. Później świątynię benedykował ksiądz Poradowski ${ }^{219}$. Potrzeba odbudowy drewnianej świątyni w latach siedemdziesiątych XVIII wieku wskazuje na fakt, że była ona zapewne już stara, co także potwierdzałoby nasze domysły o jej szybkim przy-

${ }^{213}$ Defensa Biskupstwa, s. 140-141; Heleniusz [Iwanowski], Wspomnienia, s. 267, 269, 274, 297.

${ }^{214}$ Statua, s. [679].

${ }^{215}$ Pałucki, Stan, k. 17; SGKP, t. 1, s. 193. Fundatorem wymienionym przez źródła był prawdopodobnie Ludwik Skumin Tyszkiewicz, który jako jedyny z rodu nosił tytuł generała adiutanta. Nie mamy pewności czy odbudowa świątyni przed 1748 rokiem była jego dziełem, ponieważ jego aktywność przypadła na ostatnie dziesięciolecia XVIII wieku. W 1775 roku Ludwik Tyszkiewicz został nominowany ciwunem litewskim, zmarł w 1808 roku. Urzędnicy Wielkiego Księstwa Litewskiego. Spisy, t. 1: Województwo wileńskie XIV-XVIII wiek, pod red. A. Rachuby, opr. H. Lulewicz, A. Rachuba, P. Romaniuk przy współpracy U. Jemialianczuka i A. Macuka, Warszawa 2004, s. 94, nr 254.

${ }^{216}$ Defensa Biskupstwa, s. 147v; Heleniusz [Iwanowski], Wspomnienia, s. 267, 271, 297.

${ }^{217}$ SGKP, t. 1, s. 538.

${ }^{218}$ Statua, s. [680].

${ }^{219}$ SGKP, t. 1, s. 538. 
wróceniu do funkcjonowania w XVIII wieku ${ }^{220}$. W 1782 roku odnotowano istnienie w Chabnie drewnianego kościoła parafialnego wzniesionego przez kasztelana kijowskiego Steckiego „na miejscu starodawnego” kościoła fundowanego niegdyś przez Charlęskich. Patronat kościoła należał do starosty owruckiego Steckiego ${ }^{221}$. Jedynym kasztelanem kijowskim z rodziny Steckich był Kazimierz Stanisław Stecki, który pełnił swój urząd od listopada 1722 roku do października-listopada $1748 \mathrm{roku}^{222}$. Wszystko wskazuje zatem na to, że właśnie na ten okres należy datować odbudowę chabeńskiego kościoła. Z kolei starostą owruckim i patronem świątyni z roku 1782 roku musiał być Jan Stecki występujący w latach 1779 i $1794^{223}$. Charlęscy, którzy pojawili się w Kijowszczyźnie w drugiej połowie XVI wieku ${ }^{224}$ byli bez wątpienia fundatorami pierwotnej świątyni, zniszczonej w czasie wojen kozackich.

Przed okresem 1746-1748 odbudowano kościół parafialny w Ostrohładowiczach. W czasie przeprowadzonej wtedy wizytacji zostało już odnotowane jego istnienie. Do parafii należały wówczas trzy miasteczka i $22 \mathrm{wsie}^{225}$. W $1767 \mathrm{roku}$ prawo patronatu parafii ostrohładowickiej należało do Szuyskich, a plebanem był ksiądz Maciej Siemiątkowski ${ }^{226}$. Tego samego plebana odnotował także Stan diecezji z 1782 roku, podając, że zarządzał on kościołem w Ostrohładowiczach w czasach biskupa Franciszka Ossolińskiego (co oznacza, że wiadomość ta odnosi

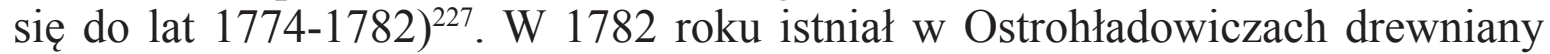
kościół parafialny fundowany „na miejscu starodawnego” przez starostę zatralskiego Szuyskiego. Prawo patronatu należało do Szuyskich ${ }^{228}$.

Zapewne na czterdzieste lata XVIII wieku powinniśmy datować pierwsze próby przywrócenia do życia parafii w Pawołoczy, która istniała co najmniej od 1626 roku $^{229}$. Po okresie długotrwałych zniszczeń i walk, w trakcie których miasto wielokrotnie zmieniało panujących, powróciło pod władzę Polski w początkach drugiej dekady XVIIII wieku. Nie było jednak wtedy warunków do odnowienia parafii pawołockiej. W 1714 roku naliczono tu zaledwie 70 chałup, a rozwój osad-

${ }^{220}$ Co prawda w 1750 roku doszło do zdobycia i obrabowania miasta przez hajdamaków (SGKP, t. 1, s. 538), co wiązało się zapewne z jakimś zniszczeniem kościoła, lecz nie wydaje się prawdopodobne, żeby zwlekano z odbudową przez następne 30 lat. Zatem odnowienie świątyni w 1780 roku musiało wynikać ze zniszczeń spowodowanych upływem czasu.

${ }^{221}$ Pałucki, Stan, k. 18v.

${ }^{222}$ Urzędnicy województw kijowskiego i czernihowskiego XV-XVIII wieku. Spisy, opr. E. Janas i W. Kłaczewski, Kórnik 2002, s. 32, nr 112.

${ }^{223}$ Tamże, s. 101, nr 689.

${ }^{224}$ A. Boniecki, Herbarz Polski, t. 2, Warszawa 1900, s. 347.

${ }^{225}$ Defensa Biskupstwa, s. 148; Heleniusz [Iwanowski], Wspomnienia, s. 267, 271, 297.

${ }^{226}$ Statua, s. [680].

${ }^{227}$ Pałucki, Stan, k. 11.

${ }^{228}$ Pałucki, Stan, k. 18v. SGKP, t. 690 wspomina o istnieniu w Ostrohładowiczach klasztoru dominikanów. Nie podaje jednak kiedy ów klasztor istniał. Być może do rodziny fundatorów i patronów parafii należał występujący w latach 1754-1756 skarbnik kijowski Wojciech Szujski. Zob.: Urzędnicy województw kijowskiego i czernihowskiego, s. 60, nr 333.

${ }^{229}$ Pałucki, Stan, k. 2; SGKP, t. 7, s. 920 podaje wiadomość, że około 1634 roku wzniesiono tu kościół. 
nictwa przerywały napady hajdamaków (np. w 1736 roku ${ }^{230}$. Wkrótce podjęto jednak kroki zmierzające do przywrócenia parafii. W latach 1746-1748 już funkcjonowała, choć jeszcze nie odbudowano kościoła parafialnego. W miejscu, gdzie wcześniej stał była kaplica, przy której był już jednak stały ksiądz. Sprawował on obowiązki duszpasterskie w czterech miastach i ich okolicach ${ }^{231}$. 15 XI 1751 roku właściciel Pawołoczy podstoli Wielkiego Księstwa Litewskiego Józef Lubomirski fundował kościół parafialny. Wyznaczył jednocześnie plac na świątynię i plebanię, zapisał kościołowi 1500 złotych annuaty oraz wieś Ksiedzówkę. Poza uposażeniem zapewnionym przez fundatora parafia otrzymała sumę 7300 złotych w postaci legat Józefa Bodakowskiego, Wojciecha Bussolskiego, Jana Białkowskiego i Jana Faleńskiego ${ }^{232}$. W 1767 roku prawo patronatu parafii pawołockiej należało do wojewody bracławskiego Stanisława Lubomirskiego, plebanem był ksiądz Stanisław Piotrowicz, a przy kościele było także dwóch wikariuszy ${ }^{233}$. Wiemy , że kanonik kijowski ksiądz Stanisław Piotrowicz był plebanem w Pawołoczy już w 1765 roku, oraz, że w 1777 roku parafia liczyła 1459 wiernych ${ }^{234}$. W 1782 roku istniał murowany kościół parafialny fundowany „,na miejscu starodawnego" przez podstolego litewskiego Lubomirskiego, a prawo patronatu należało do sukcesorek wojewodzica krakowskiego Kacpra Lubomirskiego ${ }^{235}$. Świątynia była zapewne w dobrym stanie, skoro w 1791 roku planowano odbywanie $\mathrm{w}$ niej sejmików powiatu kijowskiego ${ }^{236}$.

Bardzo skomplikowana jest kwestia ustalenia daty powstania świątyni w Pohrebyszczu. W 1751 roku hetman wielki litewski książę Michał Kazimierz Radziwiłł „Rybeńko” fundował w tym mieście kościół i klasztor franciszkanów, a biskup emauski, koadjutor kijowski Kajetan Sołtyk poświęcił nową świątynię. W 1754 roku, gdy superiorem konwentu franciszkanów był ksiądz Wojciechowski, biskup Sołtyk wydzielił także osobną parafię pohrebyskąa ${ }^{237}$. Parafia powstała z części terenów parafii pawołockiej, do której należało Pohrebyszcze w latach 1746-1748 ${ }^{238}$. Klasztor franciszkanów okazał się placówką nietrwałą i po 1754 roku nie ma śladów jego istnienia ${ }^{239}$. Tutejsza świątynia istniała jednak także w późniejszym czasie, co zostało potwierdzone w 1767 roku. Patronat parafii należał wówczas do chorążego litewskiego Stanisława Rzewuskiego, plebanem był

${ }^{230}$ SGKP, t. 7, s. 924.

${ }^{231}$ Defensa Biskupstwa, s. 145; Heleniusz [Iwanowski], Wspomnienia, s. 267, $270,297$.

${ }^{232}$ SGKP, t. 7, s. 925; Rawita-Gawroński, Studya, s. 61.

${ }^{233}$ Statua, s. [679].

${ }^{234}$ SGKP, t. 7, s. 925.

${ }^{235}$ Pałucki, Stan, k. $17 \mathrm{v}$.

${ }^{236}$ SGKP, t. 7, s. 925. W 1819 roku kościół Niepokalanego Poczęcia NMP był murowany, ale niedokończony, tymczasowy i niekonsekrowany.

${ }^{237}$ SGKP, t. 8, s. 527; Heleniusz [Iwanowski], Wspomnienia, s. 276 (gdzie także fundacja datowana na 1754 rok).

${ }^{238}$ Defensa Biskupstwa, s. 145; Heleniusz [Iwanowski], Wspomnienia, s. 270.

${ }^{239}$ Sobieraj, Fundatorzy, s. 97-243 nie podaje w ogóle wiadomości o klasztorze franciszkanów w Pohrebyszczu. Kościół w Pohrebyszczu nie został także odnotowany wśród fundacji Michała Kazimierza Radziwiłła „Rybeńko” w jego biogramie w PSB, t. 30, Wrocław-Warszawa-KrakówGdańsk, Łódź 1987, s. 305. 
Joachim Łusczyński, a wikariuszem - Konstanty Tarczewski ${ }^{240}$. Upadku klasztoru franciszkanów nie można zatem łączyć z wydarzeniami 1768 roku, gdy hajdamacy zdobyli miasto i złupili kościół ${ }^{241}$ i jego przyczyna musiała być inna. Zanikła także lokalna tradycja dotycząca jego istnienia, na co wskazuje całkowite milczenie na temat klasztoru i jego fundatora w zapisie sporządzonym w 1782 roku. Istniał wówczas drewniany (z założonymi fundamentami pod murowany) kościół parafialny fundowany przez wojewodę krakowskiego księcia Janusza Korybuta Wiśniowieckiego, który miał także posiadać prawo patronatu kościoła ${ }^{242}$. Brak wzmianki o fundacji Michała Radziwiłła może oznaczać, że była już ona całkowicie nieaktualna. Prawdopodobnie zatem kościół istniejący w 1782 roku został odbudowany na nowo po zniszczeniu poprzedniej świątyni. Założenie fundamentów pod murowany kościół świadczy o tym, że parafia była w tym czasie w stosunkowo dobrej sytuacji materialnej. Istotny problem wiąże się jednak ze wskazaną przez opis Pałuckiego osobą fundatora i rzekomego patrona parafii. Znamy dwóch wojewodów krakowskich należących do rodu Wiśniowieckich, lecz żaden z nich nie mógł być patronem parafii w 1782 roku (w tym czasie wojewodą krakowskim był Piotr Małachowski). Dymitr Jerzy Janusz Korybut Wiśniowiecki, wojewoda bełski, hetman wielki koronny i starosta białocerkiewski został nominowany na wojewodę krakowskiego 28 IX 1678 roku i sprawował ten urząd do czerwca 1680 roku. Następnie został kasztelanem krakowskim, którym był aż do swej śmierci w dniu 28 VII 1682 roku $^{243}$. Z kolei Janusz Antoni Korybut Wiśniowiecki wojewoda wileński, starosta piński i osiecki został wojewodą krakowskim 25 V 1706 roku, zaś 12 X 1726 roku awansował na kasztelanię krakowską. Pełnił ten urząd do swojej śmierci w dniu 16 lub 18 I $1741 \mathrm{roku}^{244}$. Z racji imienia wydaje się, że bardziej prawdopodobne jest uznanie za fundatora świątyni pohrebyskiej Janusza Antoniego Wiśniowieckiego. Przy takim założeniu powinniśmy uznać, że pierwotna fundacja nastąpiła przed 12 X 1726 roku (być może w związku z budową katedry i odnowieniem struktur diecezji przez biskupa Ożgę), a w każdym razie nie później niż w 1741 roku. Nie jest także wykluczone, że fundatorem klasztoru był Dymitr Jerzy Janusz Wiśniowiecki na przełomie lat siedemdziesiątych i osiemdziesiątych XVII wieku. Wówczas fundację dałoby się połączyć z już wspomnianymi próbami przywracania struktur diecezji kijowskiej przez biskupa Chryzostoma Załuskiego. Brak wzmianki o tutejszym kościele w latach 17461748 możemy thumaczyć albo brakiem realizacji zapisu fundacyjnego, albo też jego zniszczeniem przed wizytacją. Przy takim założeniu budowa klasztoru franciszkanów przez Michała Radziwiłła w 1751 roku byłaby próbą ożywienia świątyni fundowanej w pierwszej połowie XVIII wieku lub nawet w drugiej połowie poprzedniego stulecia (zresztą próbą nieudaną). Istnienie grupy zakonników przy kościele miało zapewne ułatwić jego funkcjonowanie i taki model spotykamy

${ }^{240}$ Statua, s. [679].

${ }^{241}$ SGKP, t. 8, s. 527.

${ }^{242}$ Pałucki, Stan, k. $17 \mathrm{v}$.

${ }^{243}$ Urzędnicy województwa krakowskiego XVI-XVIII wieku. Spisy, opr. S. Cynarski i A. Falniowska-Gradowska, pod red. A. Gąsiorowskiego, Kórnik 1990, s. 61, nr 126, s. 109, nr 422.

${ }^{244}$ Tamże, s. 63, nr 134, s. 110, nr 427. 
przy bardzo wielu świątyniach odbudowanych i wzniesionych w tym okresie. Także ta próba na dłuższą metę zakończyła się klęską, zatem w zapisie z 1782 roku nawiązano do fundacji pierwotnej. Kwestię przypisania patronatu parafii fundatorowi należy zapewne rozumieć w ten sposób, że prawo patronatu należało do jego następców. W 1794 roku kościół w Pohrebyszczu po raz kolejny się spalił i został odbudowany dopiero w 1814 roku $^{245}$.

Nietrwała była świątynia w Obuchowie, która wcale nie została odnotowana w czasie wizytacji z lat 1746-1748. Fakt ten można tłumaczyć położeniem miejscowości nad samą moskiewską granicą. Mimo braku wzmianki w opisach K. Orłowskiego na temat świątyni obuchowskiej możemy być pewni jej istnienia. W Obuchowie od około 1746 roku do około 1757 roku działała bowiem stacja misyjna kolegium owruckiego ${ }^{246}$. Jej upadek mógł mieć związek z nieprawnym zagarnięciem okolic Obuchowa przez rosyjskich gubernatorów kijowskich mimo formalnego pozostawania w granicach Rzeczypospolitej ${ }^{247}$.

Ostatnią grupę miejscowości, o których powinniśmy wspomnieć wśród placówek kościelnych powstałych przed 1748 rokiem stanowią te, w których możemy się domyślać istnienia świątyń na podstawie wzmianek w pracy Iwanowskiego. Odrzucamy sugestie Iwanowskiego wskazujące na możliwość istnienia w latach czterdziestych XVIII wieku kościołów zakonnych w Rzyszczowie i Uszomierzu. Świątynie te zostały omówione niżej w części poświęconej kościołom powstałym po 1748 roku. Duże wątpliwości związane są także z istnieniem kaplicy w Romanowie, należącym w latach 1746-1748 do parafii cudnowskiej. E. Iwanowski, poza odnotowaniem faktu jej funkcjonowania, podał informację, że należała ona do jezuitów, którzy ponadto prowadzili w Romanowie „najwięcej uczęszczaną” szkołę. Po kasacie zakonu przy kaplicy miał być stały ksiądz ${ }^{248}$. Poza pracą Iwanowskiego nie znajdujemy żadnego śladu działalności jezuitów w leżącym na terenie parafii cudnowskiej Romanowie przed końcem XVIII wieku ${ }^{249}$. O ile zatem nie możemy całkowicie wykluczyć istnienia tu kaplicy (choć nie wiemy dokładnie w jakim okresie, ponieważ nie występuje ona w źródłach), o tyle wiązanie jej z działalnością jezuitów jest zapewne zwykłą pomyłką. W Romanowie powstała bowiem rezydencja, a potem działało nawet kolegium jezuickie, lecz miało to

${ }^{245}$ Heleniusz [Iwanowski], Wspomnienia, s. 272. Kolejny pożar zniszczył świątynię już w 1817 roku, a hrabia Adam Wawrzeniec odbudował ją ,z muru” (SGKP, t. 8, s. 528). W 1864 roku stary kościółek Niepokalanego Poczęcia NMP został rozebrany, a na jego miejscu zbudowano nowy, większy murowany kościół (SGKP, t. 8, s. 522).

${ }^{246}$ Encyklopedia wiedzy, s. 470.

${ }^{247}$ SGKP, t. 7, s. 358.

${ }^{248}$ Heleniusz [Iwanowski], Wspomnienia, s. 268. Pozbawioną odniesienia czasowego informację o istnieniu w Romanowie kaplicy filialnej parafii Cudnów podał także SGKP, t. 9, s. 721.

${ }^{249} \mathrm{~K}$. Orłowski rzeczywiście wymienia Romanów w ramach parafii Cudnów (Defensa Biskupstwa, s. 138), lecz nie wspomina o istnieniu kaplicy w tej wsi. 
miejsce dopiero w latach 1811-1820250. W XVIII wieku istniała łacińska świątynia w miejscowości Romanowo, ale leżała ona poza obszarem diecezji kijowskiej ${ }^{251}$.

W okresie 1746-1748 miały także funkcjonować inne kaplice. Pierwsza z nich, zgodnie z sugestią Iwanowskiego istniała w Wysokiem koło Żytomierza. Miała ona należeć do parafii żytomierskiej i mieć stałego kapłana ${ }^{252}$. Nie dysponujemy żadnymi przesłankami pozwalającymi uznać jej istnienie lub brak w omawianym okresie. Pozostajemy jedynie przy stwierdzeniu, że nie została ona odnotowana przez Orłowskiego, choć samo Wysokie wymienił on w okręgu parafialnym Żytomierza ${ }^{253}$. Druga kaplica, została odnotowana przez Iwanowskiego w Zarubińcach na terenie parafii chodorkowskiej. Miała ona być obsługiwana przez kapucynów dojeżdżających z Chodorkowa ${ }^{254}$. Ponieważ wszystko wskazuje na to, że klasztor kapucynów w Chodorkowie powstał dopiero w latach sześćdziesiątych XVIII wieku, także powstanie kaplicy w Zarubińcach powinniśmy przesunąć na późniejszy okres.

\section{ROZWÓJ SIECI KOŚCIELNEJ W LATACH 1748-1782}

Wkrótce po wizytacji przeprowadzonej miedzy 1746 a 1748 rokiem zaczęły powstawać na terenie diecezji kijowskiej nowe parafie. Odbudowywano zniszczone i wznoszono nowe kościoły. Nowa parafia w Narodyczach powstała już w 1748 roku $^{255}$, a sam kościół został odnotowany przez K. Orłowskiego jeszcze w ramach parafii owruckiej. Jego fundatorem był chorąży żytomierski Pawsza ${ }^{256}$. Zapewne miały miejsce jakieś problemy z funkcjonowaniem parafii. Być może była ona słabo uposażona, co utrudniało znalezienie duchownego chętnego do jej obsadzenia. W 1765 podkomorzy owrucki Pawsza (prawdopodobnie bliski krewny fundatora świątyni) fundował tu drewniany kościół, do którego sprowadził augustianów. Zakonnikom oddano cura animarum i taki stan został odnotowany zarówno w 1767 (patronem parafii był wtedy stolnik kijowski Pawsza, zaś kościołem pozostającym pod opieką augustianów zarządzał ksiądz Nepomucen Model-

${ }^{250}$ Wołyniak [Giżycki], Zniesione, s. 190nn; Bednarski, Upadek, s. 468; Encyklopedia wiedzy, s. 574.

${ }^{251}$ Litak, Kościół łaciński, s. 320.

${ }^{252}$ SGKP, t. 14, s. 133 (informacja bez daty); Heleniusz [Iwanowski], Wspomnienia, s. 268.

${ }^{253}$ Defensa Biskupstwa, s. 136.

${ }^{254}$ SGKP, t. 14, s. 424 (wiadomość bez daty i bliższych informacji); Heleniusz [Iwanowski], Wspomnienia, s. 270.

${ }^{255}$ SGKP, t. 6, s. 914.

${ }^{256}$ Defensa Biskupstwa, s. 146v. 
ski $^{257}$ ), jak i w 1782 roku $^{258}$. W 1777 roku parafia miała 153 wiernych, a w 1799 roku została ona zniesiona ${ }^{259}$.

Karol Orłowski wymienił także w swojej pracy kościół w Trojanowie fundowany przez podkomorzego kijowskiego i starostę orzechowskiego Woronicza. Zapisano, że gdy świątynia dojdzie do odpowiedniego stanu zostanie jej przydzielona parafia ${ }^{260}$. Jednocześnie Trojanów został przez Orłowskiego zaliczony jeszcze do parafii żytomierskiej ${ }^{261}$. Wszystko to każe nam przypuszczać, że świątynia była jeszcze w 1748 roku budowana. Dziewiętnastowieczna literatura przekazała rok 1751 jako datę fundacji i wydzielenia osobnej parafii trojanowskiejejer, lecz zapewne dotyczy ona tylko drugiego wydarzenia. Kościół parafialny w Trojanowie został odnotowany w 1767 roku. Prawo patronatu tutejszej świątyni należało wówczas do Woronicza, plebanem był Józef Bielecki, a wikariuszem - Jasiński ${ }^{263}$. W 1782 roku istniał drewniany kościół parafialny fundowany przez kasztelana kijowskiego Nikodema Woronicza, którego prawo patronatu należało do kasztelana bełskiego Jakuba Woronicza ${ }^{264}$. Jednym z honorowych kanoników kapituły kijowskiej był w tym czasie dawny pleban trojanowski Józef Bielecki ${ }^{265}$.

Także na okres wizytacji z lat 1746-1748 przypadają pierwsze próby ustanowienia świątyni łacińskiej w Brusilowie. Starosta owrucki Jerzy Olszański fundował wówczas $\mathrm{w}$ tym mieście stację misyjną jezuitów podlegającą rezydencji w Białej Cerkwi. W latach 1747-1748 zgromadzono materiał i rozpoczęto budowę murowanego domu dla zakonników. Niestety już w 1748 lub 1749 roku stację w Brusiłowie zamknięto. Likwidacja misji musiała oznaczać upadek tutejszej

${ }^{257}$ Statua, s. [680].

${ }^{258}$ Pałucki, Stan, k. 18v; Wołyniak [Giżycki], Zniesione, s. 185. Fundatorem kościoła i klasztoru był bez wątpienia Jan Pawsza nominowany na podkomorzego owruckiego 11 XI 1765 roku (wcześniej był stolnikiem kijowskim), który pełnił swą godność co najmniej do grudnia 1785 roku. Zob.: Urzędnicy województw kijowskiego i czernihowskiego, s. 90, nr 605. Statua, s. [681] zawierają wiadomość, że parafia w Narodyczach była „nowa”, co może oznaczać, że powstała dopiero w czasach biskupa Józefa Andrzeja Załuskiego.

${ }^{259}$ Wołyniak [Giżycki], Zniesione, s. 185. W 1857 roku w Narodyczach ze składek parafian wzniesiono drewniany kościół pod wezwaniem św. Tekli. Było to zapewne pierwotne wezwanie tej świątyni. Zob.: SGKP, t. 6, s. 914; Wołyniak [Giżycki], Zniesione, s. 185.

${ }^{260}$ Defensa Biskupstwa, s. 142-143. Fundatorem świątyni był bez wątpienia Nikodem Kazimierz Woronicz starosta ostrzecki, podwojewodzi kijowski, w latach 1718-1724 podczaszy owrucki, w 1723 roku sędzia grodzki kijowski, pułkownik królewski, w latach 1730-1744 chorąży owrucki, w latach 1744-1748 chorąży kijowski. Urząd podkomorzego kijowskiego pełnił od 14 VI do 20 XI 1748 roku, co pozwala precyzyjnie datować fundację. Później przeszedł na kasztelanię kijowską i pełnił ten urząd jeszcze w listopadzie 1760 roku. Zmarł przed 23 VI 1762 roku. Urzędnicy województw kijowskiego i czernihowskiego, s. 21, nr 18, s. 32, nr 113, s. 47, nr 231, s. 74, nr 464, s. 88, nr 583.

${ }^{261}$ Tamże, s. 136.

${ }^{262}$ SGKP, t. 12, s. 481; Heleniusz [Iwanowski], Wspomnienia, s. 297 (gdzie brak daty, jednak z treści wynika, że kościół powstał wkrótce po 1748 roku).

${ }^{263}$ Statua, s. [679].

${ }^{264}$ Pałucki, Stan, k. 16v.

${ }^{265}$ Pałucki, Stan, k. 12v. 
świątyni, jeśli w ogóle zdołano ją wówczas zbudować. Kościół powstał wiele lat później, gdy tutejszy majątek przejęli $\mathrm{Czaccy}^{266}$. W 1780 roku podczaszy wielki koronny Feliks Szczęsny Czacki fundował kościół i klasztor kapucynów w Brusiłowie. Pierwotnie było to jedynie hospicjum, które zostało wymienione po raz pierwszy w 1782 roku $^{267}$. Zapewne równocześnie powstała tu parafia, którą wydzielono z terenu parafii chodorkowskiej (przynależność Brusiłowa do tej parafii odnotowano w latach 1746-1748 ${ }^{268}$ ). W 1782 roku został opisany kościół kapucyński posiadający cura animarum, z zaczętymi murami, fundowany titulo obsequi charitativi przez Szczęsnego Czackiego ${ }^{269}$. Budowa została ukończona przed 1796 rokiem (na pewno po 1789 roku), skoro wtedy właśnie był konsekrowany kościół. Dokonał tego biskup Cieciszowski lub biskup Pałucki. Świątynia została kanonicznie erygowana już w 1783 roku, a rok wcześniej istniała już przy niej szkoła parafialna. Tutejszy klasztor był niewielką placówką. W 1799 roku było w nim trzech zakonników ${ }^{270}$.

Biskup kijowski Kajetan Sołtyk, będąc opiekunem królewskich dóbr Stawiszcze należących do starostwa białocerkiewskiego, zbudował i uposażył w tym mieście w 1750 roku kościół parafialny położony obok zamku. Jednocześnie powołano także do życia nową parafię ${ }^{271}$. Została ona prawdopodobnie wydzielona z parafii w Białej Cerkwi, do której należało do tej pory całe starostwo białocerkiewskie $^{272}$. Starosta białocerkiewski posiadał prawo patronatu parafii stawiskiej także w 1767 roku, gdy plebanem był ksiądz Joachim Negoienko ${ }^{273}$. „Kościółek przy zamku drewniany i plebania" niewątpliwie istniały w Stawiszczach już jednak w 1763 roku. W parafii w 1777 roku odnotowano 1446 dusz. Rok później kosztem Franciszka Ksawerego Branickiego i jego żony Aleksandry z Engelhardtów (któ-

${ }^{266}$ Encyklopedia wiedzy, s. 70.

${ }^{267}$ Pałucki, Stan, k. 11 (gdzie powstanie kościoła datowane na okres sprawowania funkcji przez biskupa Franciszka Ossolińskiego, który został biskupem w 1774 roku); SGKP, t. 1, s. 390 (z określeniem czasu powstania kościoła i klasztoru na okres przed 1790 rokiem); Heleniusz [Iwanowski], Wspomnienia, s. 452; [Giżycki], Spis ważniejszych, s. 415; Wołyniak [Giżycki], Zniesione, s. 192. Pewien problem dotyczący ustalenia daty powstania omawianej świątyni sprawia informacja podana przez E. Iwanowskiego w innym miejscu (Heleniusz [Iwanowski], Wspomnienia, s. 270). Z opisu stanu parafii chodorkowskiej z lat 1746-1748 wynika, że w Brusiłowie istniał już wówczas klasztor kapucynów, do którego później przyłączono parafię. Gdyby przyjąć taki stan rzeczy musielibyśmy uznać, że w 1780 roku nastąpiła jedynie ponowna fundacja lub doposażenie klasztoru i równoczesne erygowanie osobnej parafii, która powierzono kapucynom. Za datą fundacji w 1780 roku opowiada się Sobieraj, Fundatorzy, s. 235-236. Rozwiązaniem niejasności może być założenie, że Iwanowski posiadał jakieś nieprecyzyjne informacje o istnieniu około 1748 roku świątyni zakonnej (jezuitów) w Brusiłowie. Nie wiedząc o działalności jezuitów w tym miejscu, natomiast wiedząc o istnieniu w późniejszym czasie klasztoru kapucynów, mógł powiązać informację z lat czterdziestych XVIII wieku z tym drugim zakonem.

${ }^{268}$ Defensa Biskupstwa, s. 145; Heleniusz [Iwanowski], Wspomnienia, s. 270.

${ }^{269}$ Pałucki, Stan, k. 18-18v.

${ }^{270}$ [Giżycki], Spis ważniejszych, s. 415; Wołyniak [Giżycki], Zniesione, s. 192-193.

${ }^{271}$ Pałucki, Stan, k. 17; SGKP, t. 11, s. 297, 299.

${ }^{272}$ Defensa Biskupstwa, s. 144.

${ }^{273}$ Statua, s. [680]. 
rzy od 1774 roku byli właścicielami dóbr białocerkiewskich) na miejscu dawnego drewnianego małego kościoła wzniesiono dużą świątynię pod wezwaniem Św. Trójcy. Na uposażenie kościoła nadano jednocześnie wieś Księdzówkę liczącą 40 chat oraz 1900 złotych annuaty. Fundusze kościoła powiększono legatami Wiktorii Ruszkowskiej, Kajetana Dębowskiego, księdza Jana Iwanickiego, księdza Ignacego Mohlaka, Brygidy Jakowieckiej i Żurowskiego ${ }^{274}$. W 1782 roku opisując stan diecezji kijowskiej zanotowano, że w Stawiszczach istniał drewniany kościół parafialny pierwotnie wzniesiony i uposażony przez biskupa Sołtyka, a po zamianie tutejszych dóbr z królewskich na dziedziczne hetmana wielkiego koronnego Ksawerego Branickiego przez tego ostatniego uposażony nowym funduszem (choć bez autentycznego zapisu). Hetman Branicki posiadał prawo patronatu kościoła stawiskiego ${ }^{275}$. Jako patron dbał o świątynię, czego dowodem jest fakt, że w 1798 roku wzniósł nowy murowany kościół Św. Trójcy ${ }^{276}$.

W 1750 roku odnowiono dawną świątynię w Wołodarce, którą zwano wcześniej Rozwołożem ${ }^{277}$. Fundacji dębowego kościoła św. Michała dokonała Katarzyna Mniszchowa, która po objęciu Wołodarki dążyła do jej zasiedlenia. Mąż Katarzyny - Jan Karol Mniszech zapisał jurewickim jezuitom 42 tysiące złotych zapisane na wołodarskich wsiach Hajdowie i Skwirce, za co mieli oni obsługiwać kościół i parafię w Wołodarce ${ }^{278}$. Wiele wskazuje na to, że dość długo nie dochodziło do realizacji zamierzeń fundatorki. Nabożeństwo wprowadzono do kościoła dopiero 29 IX (w dzień św. Michała) 1760 roku. Dokonali tego jezuiccy misjonarze, którym kościół odtąd podlegał („,był afiliowany”). Świątynia była wzniesiona z dębowego drewna, posiadała duży plac, cmentarz, oraz „kiepski” budynek dla misjonarzy. Jezuici stworzyli w Wołodarce stałą misję, którą obsługiwali zakonnicy dojeżdżający z Białej Cerkwi i Jurewicz ${ }^{279}$. W 1773 roku, już po kasacie jezuitów kościół i jego fundusze przejęła KEN. W 1777 roku odnotowano tutejszego komendarza, którym był ksiądz Stanisław Łagunowski ${ }^{280}$. Ostatecznie, na mocy konkordatu zawartego 26 XI 1780 roku między KEN a biskupem kijowskim Franciszkiem Ossolińskim, Komisja oddała kościół pod zarząd biskupa i kapituły kijowskiej ${ }^{281}$. Z dochodów kościoła wyznaczono wówczas annuatę dla plebana ${ }^{282}$, co należy traktować jako początek tutejszej parafii. W 1782 roku istniał w Woło-

${ }^{274}$ SGKP, t. 11, s. 299.

${ }^{275}$ Pałucki, Stan, k. 17.

${ }^{276}$ SGKP, t. 11, s. 297.

${ }^{277}$ Pałucki, Stan, k. 17v (bez daty); Encyklopedia wiedzy, s. 758. SGKP, t. 13, s. 883 zawiera błędną datę 1740 rok. Nie wspominają o świątyni w Wołodarce przekazy z czasów wizytacji K. Orłowskiego, co dowodzi, że nie powstała ona przed 1748 rokiem.

${ }^{278}$ Encyklopedia wiedzy, s. 758. Nieco inaczej fundację opisuje SGKP, t. 13, s. 885, gdzie podano, że Katarzyna Mniszchowa zapisała na uposażenie kościoła sumę 20 tysięcy złotych lokowaną na wsi Skwirce.

${ }^{279}$ SGKP, t. 13, s. 885-886; Encyklopedia wiedzy, s. 758.

${ }^{280}$ SGKP, t. 13, s. 886.

${ }^{281}$ Pałucki, Stan, k. 11 (gdzie wiadomość o odzyskaniu przez biskupa Franciszka Ossolińskiego kościoła wołodarskiego); SGKP, t. 13, s. 886.

${ }^{282}$ SGKP, t. 13, s. 886. 
darce drewniany kościół pierwotnie fundowany „na miejscu starożytnym” przez Mniszchową dla misjonarzy jezuickich. Zaznaczono, że po kasacie zakonu KEN odstąpiła prawo patronatu kościoła biskupowi i kapitule kijowskiej. Świątynia była jeszcze nie wyposażona ${ }^{283}$. Zwraca uwagę fakt, że mimo zmian prawnych dotyczących kościoła wołodarskiego, jakie nastąpiły w 1780 roku, w 1782 roku księdzem był tu nadal honorowy kanonik kapituły kijowskiej Stanisław Lagunowski ${ }^{284}$. W następnych latach duchowni zarządzający tutejszą świątynią z reguły byli związani z kapitułą. W 1785 roku proboszczem był tu ksiądz Michał Prawdzic Pałucki ${ }^{285}$ - kijowski oficjał generalny i autor opisu diecezji z 1782 roku, a w 1788 roku - kanonik katedralny kijowski ksiądz Bernard Antoni Mikoszewski. Nie wiemy jak interpretować wiadomość o wydzieleniu w tym roku tutejszej parafii ${ }^{286}$, skoro osobne dochody dla plebana wyznaczono już w 1780 roku, a co najmniej od 1785 roku notowano proboszczów. Być może ustalono teraz dokładny zasięg parafii, albo też mamy do czynienia z pomyłką literową w literaturze. W 1792 roku proboszczem w Wołodarce był kolejny kanonik katedralny kijowski, sędzia surrogat kijowski ksiądz Jan Odyniec, zaś w następnym roku na czele parafii stał komendarz ksiądz Maciej Miciński ${ }^{287}$.

W 1751 roku w Krasnopolu został zbudowany przez kasztelana wyszogrodzkiego Bartłomieja Giżyckiego kościół pod wezwaniem NMP ${ }^{288}$. W istocie była to odbudowa świątyni parafialnej, jak istniała tu w pierwszej połowie XVII wieku ${ }^{289}$, a w latach 1746-1748 jeszcze nie była odnowiona ${ }^{290}$. O kilku etapach powstawania tutejszego beneficjum mówi wyraźnie zapis z 1782 roku. Wspomniano wtedy istnienie drewnianego kościoła parafialnego fundowanego przez ordynata dubieńskiego Janusza Sanguszkę, a potem jedynie „wyposażonego” przez chorążego żytomierskiego Kajetana Giżyckiego (który posiadał także prawo patronatu kościoła $)^{291}$. Giżyccy (przy tym nie Bartłomiej lecz Kajetan ${ }^{292}$ ) są więc w 1782 roku odnotowani nie jako fundatorzy, lecz jako osoby doposażające parafię. Tymczasem z 1767 roku pochodzi zapis informujący o posiadaniu prawa patronatu parafii przez kasztelana wyszogrodzkiego Giżyckiego i o braku obsady funkcji pleba$\mathrm{na}^{293}$. Pogodzenie wszystkich wzmianek dotyczących tutejszego kościoła prowa-

${ }^{283}$ Pałucki, Stan, k. 17v.

${ }^{284}$ Pałucki, Stan, k. 12v.

${ }^{285}$ SGKP, t. 13, s. 886.

${ }^{286}$ Tamże.

287 Tamże.

${ }^{288}$ SGKP, t. 4, s. 637. Słownik podaje wezwanie Matki Boskiej. Kościół miał być zbudowany w miejscu, gdzie przed najazdami tatarskimi z XIII wieku stała cerkiew.

${ }^{289}$ Pałucki, Stan, k. 15v; Heleniusz [Iwanowski], Wspomnienia, s. 266, 296.

${ }^{290}$ Defensa Biskupstwa, s. 139; Heleniusz [Iwanowski], Wspomnienia, s. 266.

${ }^{291}$ Pałucki, Stan, k. 16v.

${ }^{292}$ Bartłomiej Giżycki otrzymał w 1740 nominację na stolnika żytomierskiego, lecz nie objął tego urzędu, zaś w 1746 został kasztelanem wyszogrodzkim. Z kolei Stanisław Kajetan Giżycki był podstolim owruckim, od 18 VIII 1779 roku - chorążym żytomierskim, zaś od 1784 roku - chorążym kijowskim. Zob: PSB, t. 8, s. 20-21; Urzędnicy województw kijowskiego i czernihowskiego, s. 111, nr 795, s. 143, nr 1065 .

${ }^{293}$ Statua, s. [679]. 
dzi nas do wniosku, że najpierw (zapewne po 1748, ale przed 1751 rokiem) doszło do fundacji parafii dokonanej przez Janusza Sanguszkę ${ }^{294}$. Kolejnymi etapami, dokonanymi już przez Giżyckich, były budowa świątyni, zwiększenie jej uposażenia i doprowadzenie do obsady przez plebana. Parafię krasnopolską wydzielono zapewne z obszaru parafii lubarskiej, do której Krasnopol należał w latach czterdziestych XVIII wieku ${ }^{295}$. W Krasnopolu powstała później także kaplica szpitalna, ale jej budowa przypadła już zapewne na XIX wiek ${ }^{296}$.

W 1754 roku właściciel Makarowa, strażnik koronny, wojewoda lubelski Antoni Lubomirski zbudował w tym mieście świątynię. Skłonił go do budowy fakt, że jego ,poddani bez chrztu umierali”. 15 III 1754 Lubomirski także uposażył nowy kościół, bo nie miał on dotąd dochodów ani plebana ${ }^{297}$. Zapewne w tym samym roku powstała parafia, wydzielona z obszaru parafii byszowskiej, do której Makarów należał w latach 1746-1748 ${ }^{298}$. W 1767 roku wojewoda lubelski Lubomirski był wciąż patronem tutejszej parafii, plebanem był kanonik katedralny kijowski Rostkowski, a wikariuszami byli księża Łaszkiewicz i Sponarski ${ }^{299}$. Rok 1768 przyniósł zaburzenia w życiu parafii makarowskiej. Lubomirski dokonał wtedy z dziekanem kapituły kijowskiej Kajetanem Rościszewskim zamiany Makarowa na Uładówkę (w Bracławskiem). W tym samym roku Kozacy Bondarenki napadli na Makarów, dokonali rzezi jego mieszkańców, splądrowali zamek i kościół. Odbudowy świątyni dokonał już nowy właściciel miasta Kajetan Rościszew$\mathrm{ski}^{300}$. Wykazał on dbałość o parafię, a jednym z tego przejawów było uruchomienie przy kościele szkółki parafialnej „dla ubogiego pospólstwa”301. W 1782 roku istniał w Makarowie drewniany kościół parafialny fundowany przez kasztelana krakowskiego księcia Lubomirskiego już zmarłego. Prawo patronatu należało do dziekana katedralnego kijowskiego Kajetana Rościszewskiego ${ }^{302}$.

Także w 1754 roku zbudowano nowy kościół pod wezwaniem NMP w Mosznach. Został on wzniesiony przez Michała Radziwiłła wraz z synem Karolem, $\mathrm{z}$ sumą zapisową 17 tysięcy złotych, w miejscu istniejącego $\mathrm{w}$ pierwszej połowie XVII wieku kościoła dominikanów, fundowanego przez Jeremiego Wiśniowie-

${ }^{294}$ Janusz Aleksander Sanguszko był ostatnim ordynatem ostrogskim. Rezydował najczęściej w Dubnie. Zmarł 13 IX 1773 roku. Zob. Żychliński, Złota księga, Rocznik V, s. 297.

${ }^{295}$ Defensa Biskupstwa, s. 139; Heleniusz [Iwanowski], Wspomnienia, s. 268.

${ }^{296}$ SGKP, t. 4, s. 637.

${ }^{297}$ SGKP, t. 5, s. 925 (gdzie tylko osoba fundatora); Heleniusz [Iwanowski], Wspomnienia, s. 270 (informacja o powstaniu kościoła po 1748 roku); Rawita-Gawroński, Studya, s. 52 (gdzie dokładne informacje). Antoni Lubomirski, wcześniej strażnik wielki koronny, rzeczywiście od 1752 roku był wojewodą lubelskim. W grudniu 1778 przeszedł na urząd wojewody krakowskiego, a w listopadzie 1779 roku - kasztelana krakowskiego. Zmarł 8 III 1782 roku. Urzędnicy województwa lubelskiego XVI-XVIII wieku. Spisy, opr. W. Kłaczewski i W. Urban, pod red. A. Gąsiorowskiego, Kórnik 1991, s. 59, nr 59; Urzędnicy województwa krakowskiego, s. 64, nr 141, s. 111, nr 434.

${ }^{298}$ Defensa Biskupstwa, s. 144; Heleniusz [Iwanowski], Wspomnienia, s. 270.

${ }^{299}$ Statua, s. [680].

${ }^{300}$ SGKP, t. 5, s. 925.

${ }^{301}$ SGKP, t. 5, s. 925; Wierzbowski, Szkoty parafjalne, s. 164.

${ }^{302}$ Pałucki, Stan, k. 18v. 
ckiego $^{303}$. Parafię wydzielono zapewne z obszaru parafii białocerkiewskiej, do której należały Moszny w latach 1746-1748 ${ }^{304}$. W 1767 roku odnotowano wspólne prawo patronatu tutejszej parafii Radziwiłłów i Morawskich oraz osobę plebana - Krzysztofa Drąszkiewicza ${ }^{305}$. W 1782 roku istniał drewniany kościół parafialny fundowany przez wojewodę wileńskiego Michała Radziwiłła. Patronat świątyni należał już tylko do Morawskich ${ }^{306}$.

Na lata 1750-1756 przypadła fundacja drewnianego kościoła i klasztoru franciszkanów konwentualnych w Borszczejówce, której dokonali właściciele wsi Brzostowscy $^{307}$. Prawdopodobnie fundacja nie została szybko zrealizowana i były jakieś kłopoty z funkcjonowaniem placówki zakonnej. Co prawda nowy dziedzic Borszczejówki Zachariasz Hański w 1765 roku potwierdził dochody dla franciszkanów w wysokości 1050 złotych rocznie, lecz w 1774 roku zakonnicy skarżyli Hańskiego w konsystorzu kijowskim o niedotrzymanie sum zawartych w akcie fundacyjnym ${ }^{308}$. Ostatecznie franciszkanie nie skorzystali z nadania, odstąpili od zamiaru budowy klasztoru i opuścili wieś, zaś w Borszczejówce pozostał kościół parafialny ${ }^{309}$. Stan diecezji z 1782 roku odnotował tu istnienie drewnianego kościoła, który był „,teraz parafialny po odstąpieniu dobrowolnym tego miejsca księ-

${ }^{303}$ SGKP, t. 6, s. 739; J. Dunin-Karwicki, Wędrówka od źródeł do ujścia Horynia, Kraków 1891, s. 24.

${ }^{304}$ Defensa Biskupstwa, s. 144; Heleniusz [Iwanowski], Wspomnienia, s. 270.

${ }^{305}$ Statua, s. [680].

${ }^{306}$ Pałucki, Stan, k. 17. W XVIII wieku było dwóch wojewodów wileńskich należących do rodu Radziwiłłów i noszących imię Michał. Fundatorem świątyni musiał być Michał Kazimierz Radziwiłł „Rybeńko”, nominowany wojewodą wileńskim 5 X 1744, zmarły 15 V 1762 roku, który miał syna Karola Stanisława „Panie Kochanku” (urodzonego w 1734 roku). Fundacja nie mogła być natomiast dziełem Michała Radziwiłła nominowanego wojewodą wileńskim 27 XI 1790 roku (zmarłego w 1831 roku), co wynika z chronologii wydarzeń (tenże Michał także miał syna Karola, urodzonego w 1777 roku, zmarłego jako niemowlę). PSB, t. 30, s. 248, 260; Urzędnicy Wielkiego Księstwa Litewskiego, t. 1, s. 197, nr 1126, 1127, 1129, 1130.

${ }^{307}$ SGKP, t. 1, s. 326; Heleniusz [Iwanowski], Wspomnienia, s. 279. Autor nie podał daty fundacji, lecz poinformował, że najstarszy zapis dla franciszkanów został 7 XII 1756 roku zapisany w aktach konsystorza kijowskiego. „Kasztelaństwo połanieccy Brzostowscy” zapisali wtedy kwotę 1050 złotych rocznie od sumy 150 tysięcy złotych dla franciszkanów. Suma została zabezpieczona na wsi Rybczycach wraz z wrębem w okolicznych lasach na zabudowania i inne potrzeby (Tamże, s. 279-280). Maciej Sobieraj datuje fundację na 1756 rok. Jako fundatorów podaje starostę dowgowskiego i przyłajskiego Adama Brzostowskiego z żoną Genowefą z Ogińskich. Zob.: Sobieraj, Fundatorzy, s. 218.

${ }^{308}$ Heleniusz [Iwanowski], Wspomnienia, s. 280.

${ }^{309}$ SGKP, t. 1, s. 326; Heleniusz [Iwanowski], Wspomnienia, s. 279-280. Jan Marek Giżycki wysnuł hipotezę, że franciszkanie, którzy opuścili Borszczejówkę znaleźli się w pobliskiej Lisiance, gdzie próby fundacji klasztoru franciszkańskiego podejmowano już od 1733 roku. Autor przypuszczał, że w latach 1757-1768 franciszkanie mieli swą siedzibę na zamku w Lisiance, a następnie zostali zabici przez hajdamaków. Z kolei od 1785/1786 roku miała działać w Lisiance prowadzona przez franciszkanów filia parafii smilańskiej, na co wskazywać miało prowadzenie od tego czasu ksiąg metrykalnych przy świątyni lisiańskiej. Wołyniak [Giżycki], Zniesione, s. 187-188. Musimy pamiętać, że Lisianka, zaliczana do starostwa korsuńskiego, (mimo, iż leżała na gruntach starostwa białocerkiewskiego), a zatem w granicach województwa kijowskiego, pod względem przynależno- 
ży franciszkanów rządzony przez podkomorzego Hańskiego Wendynę" (posiadającego prawo patronatu) bez autentycznego zapisu ${ }^{310}$. Trudno zatem stwierdzić kiedy powstała tutejsza parafia. Interpretacja zapisu z 1782 roku wskazuje na możliwość, że powstała ona po ostatecznej rezygnacji franciszkanów z budowy klasztoru. Tymczasem tutejsza parafia została odnotowana już w 1767 roku. Jej prawo patronatu nie należało jednak wtedy do Hańskich lecz do marszałka Orzeszki. Franciszkanie konwentualni, co prawda, zarządzali parafią, lecz przy świątyni był tylko jeden ksiądz - Jakub Rabczewski ${ }^{311}$, co świadczy o tym, że nie było zakonników w Borszczejówce. Jednocześnie z tego samego roku pochodzi zapis świadczący o tym, że świątynia w Borszczejówce nie była traktowana jako parafialna, lecz jako placówka związana z misją franciszkańską ${ }^{312}$. Dochodzimy zatem do wniosku, że pierwsze próby powołania do życia borszczejowskiej parafii miały miejsce najpóźniej w latach sześćdziesiątych XVIII wieku, lecz ostateczne uregulowanie jej stanu prawnego (w tym rozstrzygnięcie kwestii prawa patronatu) nastąpiło zapewne dopiero po 1774 roku. W 1785 roku Zachariasz Hański zapisał ponownie 150 tysięcy złotych na kościół parafialny, a rok później drewnianą świątynię pod wezwaniem Niepokalanego Poczęcia NMP poświęcił oficjał kijowski Michał Pałucki ${ }^{313}$. Kościół był jednak w tym czasie zupełnie opuszczony. Po 1786 roku generał Adam Rzewuski wymurował kościół, ale stan parafii nadal był daleki od stabilizacji. Próbowano nawet przenieść jej siedzibę do Nowochwastowa, ale odstąpiono od realizacji tego zamiaru. Na terenie parafii istniała w tym czasie także kaplica w Donhalówce ze stałym kapłanem unitą ${ }^{314}$.

Między 1750 a 1759 rokiem ostatecznie odnowiono dawną świątynię augustianów w Kodni. Istniejący tu przed powstaniem Chmielnickiego kościół, będący jednocześnie ośrodkiem parafii, stał się celem kozackich ataków w 1648 i 1655 roku. Odbudowany jeszcze raz w 1656 roku istniał co najmniej do roku 1670, lecz ostatecznie uległ zniszczeniu ${ }^{315}$. Augustianie przystąpili do rewindykacji swego funduszu dopiero w 1743 roku, ale proces o uposażenie zapisane w fundacji, który zakonnicy prowadzili z Głębockimi trwał aż do 1758 roku. Dopiero wtedy została zawarta ugoda, na mocy której Głęboccy zbudowali drewniane budynki kościoła i klasztoru, a biskup Kajetan Sołtyk mógł ustanowić kodeńską parafię ${ }^{316}$. Nie

ści diecezjalnej podlegała diecezji łuckiej. Zob.: Litak, Kościót łaciński, s. 388, 509. Nie była to zatem filia parafii śmilańskiej i nie wchodzi w zakres naszych zainteresowań.

${ }^{310}$ Pałucki, Stan, k. $17 \mathrm{v}$.

${ }^{311}$ Statua, s. [679].

312 Statua, s. [680]. Przy spisie parafii prowadzonych przez zakony oraz innych placówek zakonnych.

${ }^{313}$ SGKP, t. 1, s. 326 (gdzie podana błędnie suma 15 tysięcy złotych); Heleniusz [Iwanowski], Wspomnienia, s. 279-280 (gdzie podano kwotę 150 tysięcy złotych, czyli jak w pierwotnej fundacji Brzostowskich).

${ }^{314}$ Heleniusz [Iwanowski], Wspomnienia, s. 280-281.

${ }^{315}$ Defensa Biskupstwa, s. 135; Pałucki, Stan, k. 15v; Heleniusz [Iwanowski], Wspomnienia, s. 266-267, 296; Wołyniak [Giżycki], Zniesione, s. 168.

${ }^{316}$ Wołyniak [Giżycki], Zniesione, s. 168-169. Właśnie wiadomość o ustanowieniu parafii przez biskupa Sołtyka pozwala datować powstanie tutejszej parafii na lata pięćdziesiąte XVIII wieku. 
mamy jednak całkowitej pewności co do czasu powstania tutejszej parafii. Statua synodu diecezji kijowskiej wydane przez biskupa Józefa Andrzeja Załuskiego określały parafię kodeńską jako nową i wymieniały ją wraz z innymi parafiami erygowanymi już w czasach biskupa Załuskiego ${ }^{317}$, czyli najwcześniej w 1759 roku. Wydzielono ją zapewne z parafii żytomierskiej, w ramach której Kodnia została odnotowana w $1748 \mathrm{roku}^{318}$. W 1767 roku odnotowano istnienie parafii kodeńskiej, której prawo patronatu posiadała wdowa Głębocka. Parafia pozostawała pod opieką augustianów, a na jej czele stał ksiądz Hieronim Sadzikowski ${ }^{319}$. Drewniane budynki kościoła i klasztoru spłonęły w 1774 roku, a kolejne odbudowane na ich miejscu uległy wkrótce kolejnemu pożarowi. W 1778 roku podjęto budowę kolejnego klasztoru i świątyni. Tym razem niższe części budynku były dębowe, a górne - sosnowe. Plac, na którym stawiano budynki otoczono ziemnym wałem i dębowym częstokołem ${ }^{320}$. W 1782 roku odnotowano w Kodni istnienie drewnianego kościoła augustiańskiego z cura animarum fundowanego „na miejscu starodawnego" przez stolnika kijowskiego Felicjana Głębockiego ${ }^{321}$. W istocie jednak kościół nie był ukończony jeszcze w 1786 roku $^{322}$.

Najpóźniej w 1759 roku odbudowano kościół parafialny w Iwankowie. Pierwotna świątynia parafialna, która istniała w tym mieście przed powstaniem Chmielnickiego ${ }^{323}$ została zniszczona. Nie było jej jeszcze w latach 1746-1748, a sam Iwanków należał do parafii Chabno ${ }^{324}$. Fundatorką nowego kościoła pod wezwaniem Wniebowzięcia NMP była strażnikowa Wielkiego Księstwa Litewskiego Rozalia z Zahorowskich Pociejowa ${ }^{325}$. Nie znamy jednak daty tej funda-

${ }^{317}$ Statua, s. [681].

${ }^{318}$ Defensa Biskupstwa, s. 137.

${ }^{319}$ Statua, s. [679, 680].

${ }^{320}$ Wołyniak [Giżycki], Zniesione, s. 169.

${ }^{321}$ Pałucki, Stan, k. 16v. Wspomniana fundacja nastąpiła zapewne po 25 IV 1770 roku, bowiem Felicjan Głębocki wtedy właśnie objął urząd stolnika kijowskiego. Zob.: Urzędnicy województw kijowskiego i czernihowskiego, s. 65, nr 381. Oznacza to, że wymieniona w opisie Pałuckiego fundacja nie była fundacją pierwotną, która miała miejsce co najmniej kilkanaście lat wcześniej.

${ }^{322}$ Wołyniak [Giżycki], Zniesione, s. 169. Giżycki podał, że kościół był pod wezwaniem Pocieszenia MB i św. Augustyna. W 1828 roku w Kodni został zbudowany murowany kościół pod wezwaniem Pocieszenia NMP. Zob.: SGKP, t. 4, s. 241.

${ }^{323}$ Defensa Biskupstwa, s. 135; Pałucki, Stan, k. 15v-16; Heleniusz [Iwanowski], Wspomnienia, s. 267.

${ }^{324}$ Defensa Biskupstwa, s. 147v; Heleniusz [Iwanowski], Wspomnienia, s. 271, 297.

${ }^{325}$ SGKP, t. 3, s. 315. 
cji ${ }^{326}$. Posiadamy jedynie wiadomość o odbudowie kościoła w 1759 roku $^{327}$. W 1767 roku prawo patronatu parafii iwankowskiej posiadał wojewoda bracławski Lubomirski, a plebanem był ksiądz Wojciech Zawadzki ${ }^{328}$. W 1782 roku odnotowano, że w Iwankowie istniał drewniany kościół parafialny fundowany „na miejscu starodawnym" przez strażnikową Pociejową, a przez wojewodzinę kijowską Lubomirską, która sprawowała prawo patronatu, lepiej wyposażony ${ }^{329}$.

Około 1765 roku został w Bohusławie odnowiony zamek, w którym miała później istnieć drewniana kaplica ${ }^{330}$. O „,przyczynieniu” kaplicy w tym mieście informuje też relacja Michała Pałuckiego, datując jej powstanie na czasy biskupa Franciszka Ossolińskiego ${ }^{331}$, a zatem nie wcześniej niż na rok 1774. W 1782 roku istniał tu nowy, jeszcze nie wyposażony drewniany kościół parafialny, wzniesiony przez marszałka nadwornego koronnego Rzewuskiego, który także na swój koszt utrzymywał przy tej świątyni kapelana ${ }^{332}$. Parafia funkcjonowała bez wątpienia w latach osiemdziesiątych XVIII wieku, o czym świadczą liczne przekazy z tego okresu mówiące o utrzymywaniu w Bohusławie szkółki parafialnej ${ }^{333}$.

${ }^{326}$ Jeżeli uznamy za wiarygodną wiadomość przekazaną przez SGKP, t. 3, s. s. 314, że Rozalia Zahorowska, córka właściciela Iwankowa Stefana Zahorowskiego, wyszła za mąż za Antoniego Pocieja w 1685 roku dochodzimy do wniosku, że jej działalność fundacyjna po 1748 roku przypadła na stosunkowo podeszły wiek (uznajemy, że w momencie ślubu miała co najmniej około 20 lat). W przeciwnym razie (gdyby fundacja przypadła na okres przed 1748 rokiem) należałoby postawić hipotezę o tym, że nie została ona początkowo zrealizowana. Nie rozwiązuje to jednak kwestii datowania powstania kościoła. Problem stanowi sama forma zapisu zawarta w źródle. Skoro bowiem fundatorką była „strażnikowa Wielkiego Księstwa Litewskiego”, to wydaje się najprostszym rozwiązaniem przyjęcie, że fundacja odbyła się w okresie, gdy Antoni Pociej sprawował urząd strażnika wielkiego litewskiego, czyli w latach 1729-1748 (Urzędnicy centralni $i$ dostojnicy, s. 192, nr 1543). Jednocześnie jednak brak wzmianki o osobie samego Antoniego Pocieja może sugerować, że kościół powstał już po jego śmierci, gdy wdowa używała nadal dawnego tytułu. Wówczas powstanie świątyni przypadłoby na okres po 1749 roku, w tym bowiem roku zmarł Antoni Pociej (jego żona zmarła po 29 XII 1760 roku). Zob.: PSB, t. 27, Wrocław-Warszawa-Kraków-Gdańsk-Łódź 1983, s. 27-28. Urząd strażnika wielkiego litewskiego sprawowali zresztą kolejno następni przedstawiciele rodziny Pociejów - w latach 1748-1771 Ludwik, bratanek Antoniego, a następnie do lipca 1774 - Leonard. (Urzędnicy centralni i dostojnicy, s. 192, nr 1544-1545). W efekcie tytuł mógł być używany zwyczajowo w tej rodzinie przez wiele lat, co może wyjaśniać jego zastosowanie przy osobie fundatorki w okresie po zgonie jej męża.

${ }^{327}$ Heleniusz [Iwanowski], Wspomnienia, s. 267, 271.

${ }^{328}$ Statua, s. [680].

${ }^{329}$ Pałucki, Stan, k. 18v. Stanisław Lubomirski został nominowany na wojewodę kijowskiego 29 X 1772 roku (Urzędnicy województw kijowskiego i czernihowskiego, s. 68, nr 417). Doposażenie kościoła miało miejsce zapewne dopiero po tej dacie.

${ }^{330}$ SGKP, t. 1, s. 289.

${ }^{331}$ Pałucki, Stan, k. 11.

${ }^{332}$ Pałucki, Stan, k. 18. SGKP, t. 1, s. 290 datuje błędnie powstanie tego kościoła na 1789 rok, podając jego wezwanie - Zasłanie Ducha Świętego. Franciszek Rzewuski został nominowany na marszałka nadwornego koronnego 4 VIII 1775. Zob.: Urzędnicy centralni i nadworni, s. 89, nr 476. Oznacza to, że powstanie kościoła w Bohusławie nastąpiło po tej dacie.

${ }^{333}$ KENSK, z. 27, s. 78, 93, z. 29, s. 78, 93; Wierzbowski, Szkoty parafjalne, s. 121-122; Raporty Szkoły Głównej Koronnej o generalnych wizytach szkót Komisji Edukacji Narodowej 1787-1793, 
Na 1765 rok powinniśmy datować powstanie kościoła i klasztoru trynitarzy w Rzyszczowie ${ }^{334}$. Pewne wątpliwości może jedynie wzbudzać forma przekazu E. Iwanowskiego dotycząca lat 1746-1748. Autor sugerował istnienie już wtedy świątyni trynitarzy w Rzyszczowie, który należał jeszcze do parafii chwastowskiej. Jednocześnie podał wiadomość, że kościół ten stał się później kościołem parafialnym ${ }^{335}$. Pogodzenie informacji o istnieniu placówki trynitarzy przed 1748 rokiem oraz o jej powstaniu w 1765 roku jest możliwe, gdy zwrócimy uwagę na fakt, że w 1751 roku Rzyszczów został spalony przez hajdamaków ${ }^{336}$. Jest prawdopodobne, że zniszczeniu uległy także (zapewne drewniane) zabudowania klasztorne i kościół ${ }^{337}$. Przyjęcie takiej hipotezy oznaczałoby, że w 1765 roku nastąpiło jedynie odnowienie już wcześniej istniejącego klasztoru trynitarzy, którym powierzono równocześnie powołaną do życia $\mathrm{w}$ tym momencie parafię. Zasadniczym problemem w przyjęciu przedstawionej wyżej hipotezy jest zupełny brak innych świadectw wskazujących na istnienie klasztoru trynitarzy w Rzyszczowie przed 1765 rokiem. Opis K. Orłowskiego rzeczywiście wymienia miejscowość w ramach parafii chwastowskiej ${ }^{338}$, lecz na tym kończą się zbieżności tego źródła $\mathrm{z}$ pracą Iwanowskiego. W sumie zatem, nawet, jeśli uznamy, że Iwanowski uważał, że klasztor istniał już w latach czterdziestych XVIII wieku, to musimy stwierdzić, że jest to pogląd nie podparty żadnym przekazem źródłowym. W 1765 roku fundacji dokonali starosta trechtymirowski Stanisław Szczeniowski z żoną Urszulą z Nitosławskich (czasem podawany jest wśród fundatorów także ich syn podstoli winnicki Onufry Szczeniowski). Dbając o zapewnienie dostatecznych dochodów trynitarzom Szczeniowscy fundowali drewnianą świątynię pod wezwaniem św. Stanisława, klasztor, plac z mieszkaniem, ogrody oraz wieś Szczuczynkę. Zobowiązali trynitarzy do utrzymywania w klasztorze sześciu zakonników, do powinności których należało odprawianie 156 mszy rocznie, prowadzenie szpitala dla dziesięciu ubogich i szkoły parafialnej. 7 X 1765 kościół został poświęcony przez dziekana kijowskiego księdza kanonika Marcina Iwona Rybińskiego. Jednocześnie wydzielił on rzyszczowską parafię (z okręgu parafii chwastowskiej),

oprac. K. Mrozowska, Wrocław-Warszawa-Kraków-Gdańsk-Łódź 1981, s. 27, 96; Pohoska, Wizytatorowie, s. 319.

${ }^{334}$ SGKP, t. 10, s. 173; Rawita-Gawroński, Studya, s. 56; Wołyniak [Giżycki], Wspomnienie o trynitarzach na Wołyniu, Podolu i Ukrainie, Kraków 1909, s. 8, 75; [Giżycki], Spis ważniejszych, s. 461, 528-529; Wołyniak [Giżycki], Zniesione, s. 207. Nieco inne wnioski można wysnuć z wiadomości przekazanych przez Kazimierza Pułaskiego (Kronika polskich rodów szlacheckich Podola, Wotynia i Ukrainy. Monografie $i$ wzmianki, t. 1, Brody 1911, s. 220), który nie podając daty fundacji podał jedynie informację, że w 1765 roku dokonano konsekracji kościoła trynitarzy w Rzyszczowie. Sama fundacja mogła zatem nastąpić wcześniej.

${ }^{335}$ Heleniusz [Iwanowski], Wspomnienia, s. 269 (gdzie nazwa miejscowości podana w błędnej formie Rzynców), 278.

${ }^{336}$ SGKP, t. 10, s. 173; Pułaski, Kronika, s. 220.

${ }^{337}$ Biorąc pod uwagę fakt, że tutejszy kościół i klasztor zostały jeszcze raz zburzone w 1768 roku, co musiało spowodować także zniszczenie przechowywanych w budynkach dokumentów, możemy uznać za możliwe, że zatarła się pamięć o pierwotnym odnowieniu tutejszej placówki kościelnej.

${ }^{338}$ Defensa Biskupstwa, s. 143. 
która miała „wzdłuż 6 mil, wszerz - 3 mile”. Wkrótce po fundacji kościół i klasztor zostały zniszczone przez hajdamaków w czasie buntu w 1768 roku. Odbudowano je, wraz ze szkołą parafialną około 1774 roku, a w 1777 roku parafia liczyła 339 dusz $^{339}$. Zwraca uwagę fakt, że parafii rzyszczowskiej brak w spisie parafii diecezji kijowskiej z 1767 roku $^{340}$. Wszystko wskazuje zatem na to, że do tego momentu, mimo formalnej erekcji, nie wyszła ona poza fazę organizacji. W praktyce zatem zaczęła ona funkcjonować dopiero po odbudowie kościoła w latach siedemdziesiątych XVIII wieku. W 1782 roku odnotowano istnienie drewnianego kościoła trynitarskiego z cura animarum, fundowanego przez starostę trechtymiroskiego Szczeniowskiego ${ }^{341}$. Istnienie świątyni jest uchwytne w źródłach także w ostatnich latach XVIII wieku. W 1785 roku prezydentem klasztoru trynitarzy był ksiądz Rudolf od św. Bartłomieja ${ }^{342}$. 10 VI 1787 roku w aktach grodzkich kijowskich został wpisany fundusz Demetriusza Hołowińskiego na dwóch ubogich przy kościele rzyszczowskim ${ }^{343}$. W 1795 roku świątynia została benedykowana przez prezydenta klasztoru księdza Kierkieszę $e^{344}$.

Drugiej połowy lat sześćdziesiątych XVIII wieku sięgają początki świątyni parafialnej w mieście Zwingródka, choć proces organizacji parafii trwał przez dłuższy czas. 2 VIII 1766 roku starosta zwingrodzki Feliks Sołtyk dokonał fundacji kościoła ${ }^{345}$ i niektórzy uznawali to za moment powstania tutejszej parafiii ${ }^{346}$.

${ }^{339}$ Wśród wymienianych w różnych zestawieniach fundatorów bez wątpienia chodzi o starostę trechtymirowskiego (traktymirowskiego) Stanisława Szczeniowskiego i jego żonę Urszulę, córkę Franciszka Ksawerego Nitosławskiego, oraz ich syna podstolego winnickiego Onufrego Szczeniowskiego. Od września 1748 roku Stanisław Szczeniowski był miecznikiem żytomierskim, a 18 VIII 1759 roku awansował na urząd podczaszego żytomierskiego. Zmarł przed 1 X 1776 roku. Zob.: Niesiecki, Herbarz Polski, t. 7, s. 571; Urzędnicy województw kijowskiego i czernihowskiego, s. 123, nr 902, s. 129, nr 949. Oznacza to, że działalność fundacyjną Stanisława i Urszuli Szczeniowskich należy umieszczać w pierwszych latach drugiej połowy XVIII wieku, co jednak w żaden sposób nie przeczy hipotezie o wcześniejszym istnieniu klasztoru w Rzyszczowie. Skoro już w latach czterdziestych XVIII wieku Stanisław Szczeniowski sprawował urzędy na Żytomierszczyźnie, to mógł już wtedy być właścicielem Rzyszczowa i patronem hipotetycznego klasztoru. Ten fakt mógł go także skłonić do fundowania w 1765 roku na nowo zniszczonej placówki trynitarzy. SGKP, t. 10, s. 173-174; Rawita-Gawroński, Studya, s. 56; Wołyniak [Giżycki], Wspomnienie, s. 8, 75-76; [Giżycki], Spis ważniejszych, s. 461, 528-529; Heleniusz [Iwanowski], Wspomnienia, s. 278; K. Pułaski, Kronika, s. 220; Wołyniak [Giżycki], Zniesione, s. 207-208. Iwanowski podał też wiadomość, że „obywatele chcieli słuchać mszy”, więc na terenie powstałej parafii fundowali siedem kaplic, do których dojeżdżali trynitarze lub wysyłali tam zakonników (s. 279). Kaplice powstały w następujących miejscowościach: Koziarewicze, Kozińce, Makiedony, Medwedówka, Mikołajówka, Prucki Wielkie i Tulińce. Nie wiemy jednak kiedy je zbudowano. Możliwe, że nastąpiło to dopiero w XIX wieku.

${ }^{340}$ Statua, s. [679-681].

${ }^{341}$ Pałucki, Stan, k. 17v.

${ }^{342}$ SGKP, t. 10, s. 174; Wołyniak [Giżycki], Zniesione, s. 208.

${ }^{343}$ Heleniusz [Iwanowski], Wspomnienia, s. 278.

${ }^{344}$ SGKP, t. 10, s. 174 . W 1813 roku klasztor został wymurowany. W 1829 roku na miejscu drewnianego wzniesiono murowany kościół, a trynitarze prowadzili parafię do 1832 roku.

${ }^{345}$ SGKP, t. 14, s. 694; Heleniusz [Iwanowski], Wspomnienia, s. 287.

${ }^{346}$ SGKP, t. 14, s. 690. 
Tymczasem budowa świątyni rozpoczęła się kilka lat później, w 1770 roku, gdy ksiądz kanonik M. Pałucki benedykował kamienie na jej fundamenty ${ }^{347}$, a formalnej zgody na budowę biskup kijowski udzielił dopiero w 1773 roku $^{348}$. Powstanie kościoła parafialnego w Zwingródce datowano na czasy biskupa Franciszka Ossolińskiego ${ }^{349}$ (a więc nie wcześniej niż na 1774 rok). Zapewne ważnym etapem powstawania parafii było zatwierdzenie aktu fundacji wystawionego przez Sołtyka. Ponieważ Zwingródka była królewszczyzną i kościół pozostawał pod królewskim patronatem, akt został zatwierdzony przez Stanisława Augusta, a miało to miejsce 14 XII 1776 roku. Król zatwierdzając fundację świątyni uzupełnił ją nadając annuatę w wysokości 1600 złotych z dochodów starostwa, orne pole, sianożęć, młyn i dwa kamienie łoju z miast Zwingródka i Kalnebłota ${ }^{350}$. Pierwszego plebana zwingrodzkiego odnotowano w 1780 roku. Był nim ksiądz Łojecki ${ }^{351}$. W 1782 roku odnotowano istnienie drewnianego kościoła parafialnego, którego patronat należał do króla, fundowanego przez starostę zwingrodzkiego Sołtyka za zgodą Stanisława Augusta ${ }^{352}$. Nie wiemy jak odnieść się do informacji mówiącej o ustanowieniu w 1786 roku parafii zwingrodzkiej poprzez wyłączenie pewnych wsi należących dotąd do parafii śmilskiej ${ }^{353}$. Albo nastąpiła wtedy jakaś prawna regulacja dotycząca określenia przynależności wsi do konkretnych parafii na rozległych obszarach diecezji, albo mamy do czynienia z pomyłką polegającą na pomyleniu dat dotyczących powstania tutejszej parafii $(1766,1776,1786)$. Kościół parafialny w Zwingródce aż do 1800 roku był drewniany ${ }^{354}$.

Podobny problem, jak w przypadku świątyni rzyszczowskiej, dotyczy kwestii powstania kościoła i klasztoru karmelitów trzewiczkowych w Uszomierzu. Przekaz Iwanowskiego dotyczący lat 1746-1748 wskazuje na możliwość, że świątynia karmelitów już wówczas istniała, choć miasto należało jeszcze do parafii wielednickiej. Dopiero w późniejszym czasie miała tu powstać osobna parafia ${ }^{355}$. Jedynym elementem, który znajdujemy w dziele K. Orłowskiego, na którym miał opierać się Iwanowski, jest zaliczenie Uszomierza do parafii Wieledniki ${ }^{356}$. Oznacza to, że dopóki nie odnajdziemy źródeł potwierdzających sugestię Iwanowskiego powinniśmy raczej uznać, że klasztor i kościół powstały po 1748 roku. Fundacji kościoła parafialnego w Uszomierzu dokonały 2 I 1767 roku Antonina (Anna)

${ }^{347}$ SGKP, t. 14, s. 694; Heleniusz [Iwanowski], Wspomnienia, s. 287.

${ }^{348}$ Heleniusz [Iwanowski], Wspomnienia, s. 287.

${ }^{349}$ Pałucki, Stan, k. 11 (gdzie zapisano, że biskup „przyczynił” tutejszy kościół parafialny).

${ }^{350}$ SGKP, t. 14, s. 694; Heleniusz [Iwanowski], Wspomnienia, s. 287.

${ }^{351}$ SGKP, t. 14, s. 694.

${ }^{352}$ Pałucki, Stan, k. $17 \mathrm{v}$.

${ }^{353}$ Heleniusz [Iwanowski], Wspomnienia, s. 287; Wołyniak [Giżycki], Zniesione, s. 187.

${ }^{354}$ Heleniusz [Iwanowski], Wspomnienia, s. 288. Starościna zwingrodzka Salomea Sołtykowa zapisała sumę na wymurowanie nowego kościoła w miejsce drewnianego, jednak jej śmierć w 1803 roku nie pozwoliła zrealizować tego zamiaru. Suma zapisu okazała się zresztą zbyt mała. Dopiero po uzupełnieniu sumy dokończono w 1819 roku budowę nowej świątyni pod wezwaniem Przemienienia Pańskiego. Zob.: SGKP, t. 14, s. 696 (Tamże, s. 690 informacja o wzniesieniu przez Sołtyka w 1809 roku murowanego kościoła Opatrzności Bożej).

${ }^{355}$ Heleniusz [Iwanowski], Wspomnienia, s. 271.

${ }^{356}$ Defensa Biskupstwa, s. 146v. 
z Bohuszów primo voto Dubrawska, secundo voto Wojnarowska oraz wicestarościna owrucka Anna Dominika z Młodeckich Bohuszowa, później Dubrawska, zapisując na uposażenie 12 tysięcy złotych. Następnie w 1781 roku sędzina grodzka żytomierska Anna Dominika Dubrowska oddała kościół karmelitom i zapewniła im odpowiednie uposażenie przeznaczając na ich rzecz sumę z dawnego zapisu. Ponadto jej brat Józef Dubrowski (sam będąc karmelitą) zapisał klasztorowi z własnej ojcowizny dodatkowe 10 tysięcy złotych. Ówczesny zarządca świątyni dziekan owrucki, kanonik kijowski Samuel Modliszewski zrzekł się jej na rzecz zakonników $\mathrm{w}^{357}$. Musiały być jakieś problemy z realizacją fundacji, skoro w 1782 roku odnotowano istnienie w Uszomierzu drewnianego kościoła fundowanego „niegdyś” przez Andrzeja i Annę Dubrawskich dla karmelitów trzewiczkowych, a po zaskarżeniu fundatorów tego zapisu afiliowany do kościoła wielednickiego $^{358}$. Treść powyższego przekazu wskazuje na nieobecność karmelitów przy kościele. Pojawili się oni chyba jednak w latach osiemdziesiątych, bowiem przekazy z XIX wieku mówiły o tym, że w mieście istniał „dawniej” klasztor karmelitów trzewiczkowych fundowany przez Annę Bohuszową, zmarłą w 1786 roku $^{359}$. Zastanawiający jest fakt, że mimo iż klasztor powstał stosunkowo krótko przed 1782 rokiem, zapisano, że fundacja odbyła się „,niegdyś”. Jedyny Andrzej Dubrawski występuje w latach sześćdziesiątych i siedemdziesiątych XVIIII wieku, w tym samym okresie żyła także Anna Dubrawska z Wąsowskich (która zmarła najpóźniej w $1767 \mathrm{roku})^{360}$. Przyjmując tożsamość wspomnianych osób z fundatorami kościoła i klasztoru karmelitów powinniśmy datować fundację na lata sześćdziesiąte XVIII stulecia, a zatem założyć, że pierwotna fundacja od razu zakładała sprowadzenie karmelitów, co jednak znacznie odwlekło się w czasie. W 1793 roku świątynia ponownie stała się kościołem parafialnym ${ }^{361}$.

W 1777 roku powstał murowany kościół parafialny w Białolówce. Świątynia została fundowana przez miecznikową litewską Marię z Lubomirskich Radziwiłłową, żonę księcia Karola Radziwiłła „Panie Kochanku” ${ }^{362}$. W 1782 roku odnotowano, że kościół, którego prawo patronatu wciąż posiadała fundatorka, powstał na miejscu dawnej świątyni parafialnej, która istniała tu przed powstaniem Chmielnickiego ${ }^{363}$. Parafia, która powstała przez wydzielenie części parafii pawo-

${ }^{357}$ Wołyniak [Giżycki], Zniesione, s. 199-200. Encyklopedja kościelna, t. 10, s. 43 łączy fakt powstania kościoła i klasztoru i datuje fundację na 1772 rok.

${ }^{358}$ Pałucki, Stan, k. 18.

${ }^{359}$ SGKP, t. 12, s. 856.

${ }^{360}$ Andrzej Dubrawski był podczaszycem bracławskim, w 1764 roku - posłem z województwa kijowskiego, w 1766 roku pełnił urząd podstarościego owruckiego, a w 1777 roku - sędziego grodzkiego żytomierskiego. Zob. Boniecki, Herbarz Polski, t. 5, Warszawa 1902, s. 69.

${ }^{361}$ Wołyniak [Giżycki], Zniesione, s. 200.

${ }^{362}$ Pałucki, Stan, k. 11, 17v; SGKP, t. 1, s. 192; Heleniusz [Iwanowski], Wspomnienia, s. 269270, 273. Istnienie kościoła parafialnego jest kilkakrotnie wzmiankowane w drugiej połowie XVIII wieku. Ostatni raz w tym okresie w 1798 roku. Zob. Rawita-Gawroński, Studya, s. 63.

${ }^{363}$ Pałucki, Stan, k. 17v. 
łockiej ${ }^{364}$, nie była zapewne zbyt bogata. Świadczy o tym fakt, że w 1787 roku pleban Ostrowski gościł biskupa Naruszewicza „w swojej lepionej chacie”365.

W latach siedemdziesiątych XVIII wieku należy umieścić odnowienie parafii w Leszczynie. W latach 1746-1748 tutejszy kościół parafialny nie był jeszcze odbudowany, a sam Leszczyn należał do parafii żytomierskiej ${ }^{366}$. W 1782 roku odnotowano istnienie drewnianego kościoła parafialnego, fundowanego „na miejscu starodawnego" przez starostę dąbrowickiego Polanowskiego, który posiadał także jego prawo patronatu ${ }^{367}$. Jedyną wskazówką pozwalającą bliżej określić czas odbudowy świątyni w Leszczynie jest informacja, że kościół został „przyczyniony" przez biskupa Franciszka Ossolińskiego ${ }^{368}$. Nastąpiło to zatem nie wcześniej niż w 1774 roku. Jednocześnie możemy także przypuszczać, że niezbyt blisko 1782 roku, skoro nie opisano wtedy kościoła jako budynku nowego.

W 1780 roku powstał drewniany kościół parafialny w mieście Malin. Jego fundatorem był pisarz ziemski bracławski Ignacy (lub Stanisław) Kordysz ${ }^{369}$. W 1782 roku kościół odnotowano jako „nowo wybudowany” i ,jeszcze nie dotowany" ${ }^{370}$, co sugeruje, że parafia wciąż jeszcze była wtedy w fazie organizacji. Wkrótce zapewne uzyskała ona normalny status, skoro w 1784 roku świątynia została benedykowana przez tutejszego plebana księdza Rajmunda Zakrzewskie$\mathrm{go}^{371}$. Parafia malińska została utworzona poprzez wydzielenie części parafii korosteszowskiej lub chabeńskiej. Miejscowość o nazwie Malin została odnotowana w latach 1746-1748 tak w jednej, jak w drugiej z wymienionych wyżej parafii ${ }^{372}$.

W 1781 roku został fundowany i wybudowany murowany kościół parafialny pod wezwaniem św. Antoniego Padewskiego w Kotelni. Fundatorem był wojski kijowski Ursyn (lub Antoni) Pruszyński, który posiadał tez prawo patronatu para$\mathrm{fii}^{373}$. Było to w rzeczywistości odnowienie dawnej parafii, istniejącej przed powstaniem Chmielnickiego ${ }^{374}$. Kościół został fundowany „,na miejscu starodawne-

${ }^{364}$ W latach 1746-1748 Białołówka należała do parafii pawołockiej. Defensa Biskupstwa, s. 145; Iwanowski zalicza miejscowość raz do parafii Białopole (Heleniusz [Iwanowski], Wspomnienia, s. 269), zaś innym razem do parafii Pawołocz (Tamże, s. 270).

${ }^{365}$ SGKP, t. 1, s. 192.

${ }^{366}$ Defensa Biskupstwa, s. 137; Heleniusz [Iwanowski], Wspomnienia, s. 267-268.

${ }^{367}$ Pałucki, Stan, 17.

${ }^{368}$ Pałucki, Stan, k. 11.

${ }^{369}$ Pałucki, Stan, k. 17 (gdzie imię fundatora podano jako Ignacy); SGKP, t. 6, s. 14 (informacja $\mathrm{z}$ datą oraz imieniem fundatora - Stanisław).

${ }^{370}$ Pałucki, Stan, k. 17.

${ }^{371}$ SGKP, t. 6, s. 14.

${ }^{372}$ Defensa Biskupstwa, s. 142 (Korosteszów), 147v (Chabne).

${ }^{373}$ Pałucki, Stan, k. 11 (gdzie jedynie wiadomość bez daty o „przyczynieniu” kościoła w czasach biskupa Franciszka Ossolińskiego, czyli po 1774 roku), 17 (gdzie informacja o osobie fundatora - Ursynie Pruszyńskim i o tym, że kościół był „nowo murowany”); SGKP, t. 4, s. 492 (gdzie podana data fundacji i osoba fundatora - Antoni Pruszyński). Antoni Pruszyński, wcześniej wojski mniejszy owrucki, został nominowany wojskim kijowskim 22 I 1777 roku, zaś 5 V 1784 roku awansował na stolnika koronnego. Zob.: Urzędnicy województw kijowskiego i czernihowskiego, s. 72, nr 447; PSB, t. 28, s. 613.

${ }^{374}$ Pałucki, Stan, k. 15v; Heleniusz [Iwanowski], Wspomnienia, s. 266, 296. 
go"375, a parafia wydzielona zapewne z obszaru parafii żytomierskiej, do której Kotelnia należała w latach 1746-1748 ${ }^{376}$.

W 1761 roku powstał filialny kościół w Iwnicy, który należał do parafii korosteszowskiej ${ }^{377}$, mimo, iż w 1748 roku miasto należało do parafii chodorkowskiej $^{378}$. Początkowo planowano zapewne utworzenie tu osobnej parafii. Istnieje przekaz, że w 1762 roku (a więc już rok po fundacji) biskup Józef Załuski konsekrował w erygowanej przez siebie nowej parafii w Iwnicy kościół uposażony przez kasztelana bracławskiego Jana Czarneckiego ${ }^{379}$. Także w 1767 roku tutejsza świątynia została odnotowana wśród kościołów parafialnych. Prawo patronatu tutejszej parafii należało wówczas nadal do kasztelana bracławskiego Czarneckiego, a plebanem był paulin Jan Czosnowski ${ }^{380}$. Z nieznanych nam przyczyn nie powiodła się pierwsza próba założenia parafii w Iwnicy i tutejszy kościół został na dłuższy czas świątynią filialną. W 1782 roku zanotowano, że w Iwnicy istniał drewniany kościół fundowany przez podkomorzego lwowskiego Łętowskiego. Kościół nie posiadał stałych dochodów (był ,sine dote”) i pozostawał filią kościoła leszczyńskiego ${ }^{381}$. Nie wiemy kiedy nastąpiło przekazanie Iwnicy z parafii Chodorków do parafii Korosteszów, a potem do parafii Leszczyn. Być może druga $\mathrm{z}$ tych zmian nastąpiła w momencie powstania kościoła w Leszczynie. Problemem jest także identyfikacja osoby fundatora. Źródła nie notują podkomorzego lwowskiego noszącego nazwisko Łętowski. Występował co prawda noszący podobne nazwisko Jerzy Antoni Łączyński, który wśród wielu innych sprawował także urząd podkomorzego lwowskiego, lecz upatrywanie w nim wymienionego w źródle fundatora kościoła w Iwnicy może wzbudzać poważne wątpliwości ${ }^{382}$. Fundatorem kościoła iwnickiego był raczej Stanisław Łętowski, podstoli, a później podkomorzy krakowski ${ }^{383}$. We wrześniu 1783 roku stolnik zwinogrodzki i starosta karoliński Józef Czarnecki z żoną Domicelą fundował kościół i klasztor

${ }^{375}$ Pałucki, Stan, k. 17.

${ }^{376}$ Defensa Biskupstwa, s. 137; Heleniusz [Iwanowski], Wspomnienia, s. 268.

${ }^{377}$ Wołyniak [Giżycki], Zniesione, s. 186.

${ }^{378}$ Defensa Biskupstwa, s. 145; Heleniusz [Iwanowski], Wspomnienia, s. 270.

${ }^{379}$ Statua, s. [679, 681].

${ }^{380}$ Statua, s. [679].

${ }^{381}$ Pałucki, Stan, k. 17.

382 Jerzy Antoni Łączyński był najpierw podwojewodzim lwowskim, następnie kolejno od 1724 roku skarbnikiem przemyskim, od 1737 roku chorążym lwowskim, od 1738 roku podkomorzym lwowskim, od 1746 kasztelanem lwowskim. Pełniąc ten ostatni urząd zmarł przed 15 VII 1754 roku. Zob.: PSB, t. 18, Wrocław-Warszawa-Kraków-Gdańsk 1973, s. 313; Urzędnicy województwa ruskiego XIV-XVIII wieku (ziemie halicka, lwowska, przemyska, sanocka). Spisy, opr. K. Przyboś, Wrocław-Warszawa-Kraków-Gdańsk-Łódź 1987, s. 111, nr 787, s. 134, nr 1014, s. 119, nr 860, s. 167-168, nr 1316, s. 235, s. 2006. Przeciwko utożsamieniu Łączyńskiego z fundatorem omawianej świątyni przemawia przede wszystkim inne (choć podobne) nazwisko. Poza tym, jeśli kościół powstał po 1748 roku, to jego fundator używałby raczej wyższego tytułu kasztelana lwowskiego. $\mathrm{Z}$ drugiej strony być może sama fundacja miała miejsce przed awansem na kasztelanię lwowską w 1746 roku, a jedynie opóźniła się jej realizacja.

${ }^{383}$ Stanisław Lętowski (zmarły w 1776 roku) od 1759 roku był podkomorzym krakowskim. Był on właścicielem Iwnicy, w której wzniósł kościół i fundował parafię. Później sprzedał Iwnicę. PSB, 
franciszkanów konwentualnych w Iwnicy oraz drewniany kościół św. Jana Chrzciciela $^{384}$. Nie jest jasne czy była to druga świątynia łacińska w mieście, czy raczej tylko nowy budynek, który zastąpił stary kościół. W 1793 roku kościół franciszkański stał się ośrodkiem parafii ${ }^{385}$, lecz część literatury wspomina o istnieniu parafii iwnickiej już w 1783 roku $^{386}$. Oznaczałoby to, że jednak przez pewien czas w mieście były dwie świątynie: kościół franciszkanów, oraz wcześniej fundowany przez Łętowskiego kościół filialny, który stał się ośrodkiem parafii ${ }^{387}$.

Poza kościołami na terenie diecezji kijowskiej powstały w XVIII wieku liczne kaplice stanowiąc istotne uzupełnienie sieci świątyń łacińskich. Były one jednak najczęściej mniej trwałym elementem tej sieci i tylko w niewielkim stopniu są one zapewne uchwytne w źródłach.

Wyjątkiem od tej reguły była kaplica w Śmile, która, mimo burzliwych dziejów, stała się ostatecznie nawet ośrodkiem parafii. W latach 1746-1748 Śmiła należała do parafii białocerkiewskiej i nie posiadała własnej świątyni ${ }^{388}$. Na początku drugiej połowy XVIII wieku Jerzy Domański, rządca tutejszych dóbr Stanisława Lubomirskiego, wzniósł na górze zamkowej koło miasta kaplicę pod wezwaniem św. Barbary. W kaplicy tej funkcję kapelana w latach 1762-1766 pełnił franciszkanin ksiądz Sznurecki ${ }^{389}$. Nie wiemy dokładnie kiedy, ale właśnie w latach sześćdziesiątych XVIII wieku odszło do pierwszej próby ustanowienia odrębnej parafii z centrum w Śmile. Dowodem na to jest odnotowanie tutejszej świątyni w spisie parafii diecezji kijowskej w 1767 roku. Prawo patronatu, pozostającej pod opieką franciszkanów konwentualnych, parafii posiadał wówczas wojewoda nowogrodzki Jabłonowski, a świątynią zarządzał ksiądz Pruchnickijio. W roku 1768 hajdamacy pod wodzą Żeleźniaka dokonali w Śmile rzezi ludności i spalili świątynię, zaś rok później spadł na miasto najazd tatarski. Śmiła została zrujnowana, co oznaczało także zapewne kres funkcjonowania tutejszej parafii. Aby umożliwić szybszą jej odbudowę Stanisław August nadał miastu w 1773 roku prawo magdeburskie ${ }^{391}$. Wkrótce $\mathrm{w}$ domu sędziego prawa magdeburskiego Nowickiego powstało prywatne oratorium. Było ono jedynym obiektem sakralnym w mieście aż do 1777 roku, gdy kosztem Franciszka Ksawerego Lubomirskiego zbudowano kaplicę pod wezwaniem św. Franciszka Ksawerego ${ }^{392}$. W 1782

t. 18 , s. 366. Należy przyjąć, że opis M. Pałuckiego zawiera błąd polegający na zamianie tytułu podkomorzego krakowskiego na lwowskiego.

${ }^{384}$ Wołyniak [Giżycki], Z przeszłości, s. 79; [Giżycki], Spis ważniejszych, s. 571; Wołyniak [Giżycki], Zniesione, s. 186; Sobieraj, Fundatorzy, s. 223.

${ }^{385}$ Wołyniak [Giżycki], Zniesione, s. 186.

${ }^{386}$ Sobieraj, Fundatorzy, s. 223.

${ }^{387}$ W 1826 roku zbudowano w Iwnicy nowy kościół pod wezwaniem św. Jana Chrzciciela (SGKP, t. 3, s. 326).

${ }^{388}$ Defensa Biskupstwa, s. 144; Heleniusz [Iwanowski], Wspomnienia, s. 269.

${ }^{389}$ SGKP, t. 10 , s. 881.

${ }^{390}$ Statua, s. [680].

${ }^{391}$ SGKP, t. 10, s. 882.

${ }^{392}$ SGKP, t. 10, s. 883. O „przyczynieniu” kaplicy w Śmile przez biskupa Franciszka Ossolińskiego (w latach 1774-1782) wspomina także Stan, k. 11. 
roku księdzem w Śmile był Jan Sokołowski, honorowy kanonik kapituły kijowskiej ${ }^{393}$. Odnotowano jednocześnie istnienie drewnianej kaplicy publicznej fundowanej przez księcia Stanisława Lubomirskiego „dla wygody dworskich”, a utrzymywanej przez księcia Ksawerego Lubomirskiego. Kaplica posiadała cura animarum przyłączoną przez sufragana kijowskiego Zambrzuckiego podczas przeprowadzanej przez niego wizyty generalnej ${ }^{394}$. W 1783 roku Franciszek Ksawery Lubomirski fundował w Śmile klasztor kapucynów ${ }^{395}$. Akt erekcji przewidywał, że w klasztorze będzie czterech, a potem 12 zakonników aby „utrzymać cura animarum". Na uposażenie klasztoru zapisano wrąb w lasach na opał i łowienie ryb w Serebriańskim Stawie. Pierwszymi przełożonymi klasztoru zostali ksiądz Narcyz i ksiądz Leonard ${ }^{396}$. Dwa lata po fundacji Franciszek Ksawery Lubomirski wystawił kaplicę z małym budynkiem dla kapucynów, ale nigdy nie wzniesiono kościoła ani większego klasztoru ${ }^{397}$. W 1786 roku w parafii było u spowiedzi wielkanocnej 400 osób, a na terenie parafii działały także dwie kaplice (w Orłowcu i Zielonej Dąbrowie) ${ }^{398}$. W 1787 roku Śmielszczyzna została sprzedana księciu Grzegorzowi Potiemkinowi, co zupełnie zmieniło położenie kapucynów. W następnym roku, gdy przełożonym klasztoru został ksiądz Leonard, zajmujący miejsce proboszcza, a kaznodzieją był ksiądz Firmat, zakonnicy „, bez nadziei na osiedlenie" opuścili Śmiłę. Stało się to, mimo posiadania przez nich domu w drewnianej oficynie koło kościoła i prowadzenia w prywatnym domu szkółki parafialnej ${ }^{399}$. Wyjazd kapucynów spowodował konieczność przeprowadzenia zmian w administracji tutejszej parafii. 7 IX 1788 roku generalny konsystorz kijowski wyznaczył podkustosza katedry kijowskiej księdza Józefa Rolicza Kłosowskiego proboszczem parafii śmilskiej, a świątynia stała się kościołem parafialnym ${ }^{400}$. Ksiądz Rolicz był proboszczem do 1792 roku. W tym roku komendarzem parafii został ksiądz Stefan Łapicki, a w 1793 - ksiądz Stanisław Trębicki, który został później proboszczem. Za jego czasów ogrodzono kościół i cmentarz, zaś altarysta ksiądz Szokali utrzymywał szkołę parafialną. W 1794 roku świątynia została benedykowana przez księdza Rafała Czernichowskiego. Proboszcz Trębicki uzyskał od księcia Potiemkina zapis (zamiast wcześniejszego zapisu Lubomirskiego dla

${ }^{393}$ Pałucki, Stan, k. 12 v.

${ }^{394}$ Pałucki, Stan, k. 17v-18.

${ }^{395}$ SGKP, t. 10, s. 883; Sobieraj, Fundatorzy, s. 241.

${ }^{396}$ SGKP, t. 10, s. 883.

${ }^{397}$ Heleniusz [Iwanowski], Wspomnienia, s. 269 (gdzie jedynie pozbawiona odniesienia czasowego wiadomość o powstaniu parafii), 452 (informacja o przetrwaniu placówki kapucynów przez 10 lat bez konkretnych dat); Dokładniejsze, lecz nieco inne wiadomości (pobyt kapucynów w Śmile znacznie krótszy) podał [Giżycki], Spis ważniejszych, s. 416-417.

${ }^{398}$ SGKP, t. 10 s. 883 . Zupełnie inną liczbę - 1787 dusz spowiadających się (zapewne będącą efektem błędu literowego) podał SGKP, t. 10, s. 884. Poprawiamy datę istnienia kaplic z 1768 na 1786 rok, co wynika z kolejności wydarzeń przekazanych przez tekst.

${ }^{399}$ SGKP, t. 10, s. 883; [Giżycki], Spis ważniejszych, s. 417; Sobieraj, Fundatorzy, s. 241.

${ }^{400}$ SGKP, t. 10 , s. 883-884. 
kapucynów), aby kościołowi wypłacano co rok 100 srebrnych rubli, dawano ordynarię i naprawiano budynki kościelne ${ }^{401}$.

Dziedzic Rokitnej regent koronny Józef Karwicki zbudował w tym mieście w 1774 roku kaplicę publiczną z rezydencją dla księży i izbą dla służby ${ }^{402}$. W ten sposób nawiązano do tradycji z pierwszej połowy XVII wieku, kiedy istniała kaplica $\mathrm{w}$ tutejszym zamku ${ }^{403}$. Istnienie drewnianej kaplicy publicznej zostało potwierdzone także w latach 1781 i 1782. Miała być ona wystawiona przez kasztelana połanieckiego Dunina-Karwickiego dla wygody mieszkańców. Utrzymywał on stale kapelana i obiecywał zapisać fundusz, czego jednak nie czynił ${ }^{404}$. Po 1782 roku komisarz białocerkiewski Borkowski wzniósł w Rokitnej także drewniany kościól ${ }^{405}$. Z kolei na miejscu kaplicy publicznej zbudowano drewniany kościół pod wezwaniem św. Józefa, który jednak nie został ukończony i pozostał niekonsekrowany ${ }^{406}$.

W 1782 roku odnotowano istnienie drewnianej kaplicy w Horoszkach. Kaplica została wzniesiona przez częstochowskich paulinów będących właścicielami tutejszych dóbr. Była filią kościoła żytomierskiego ${ }^{407}$. Nie odbudowano kościoła parafialnego, który istniał przed 1648 roku w Brahinie ${ }^{408}$. W 1782 roku odnotowano jedynie istnienie w tym mieście kaplicy bez uposażenia (,sine dote”) przyłączonej do kościoła jurowickiego ${ }^{409}$.

${ }^{401}$ SGKP, t. 10, s. 884. Słownik datuje uzyskanie zapisu księcia Potiemkina na 1790 rok, co jest oczywistym błędem, jeśli zwrócimy uwagę na inne daty. Ksiądz Trębicki został proboszczem nie wcześniej niż w 1793 roku, a wypłacanie sum w rublach wskazuje na sytuację zaistniałą po 1795 roku. Kościół chylił się ku upadkowi i po śmierci księdza Trębickiego proboszcz dominikanin Rajmund Wereszycki uzyskał od hrabiego Aleksandra Samojłowa zapomogę na budowę nowej świątyni. Nowy drewniany kościół wzniesiono w latach 1805-1809 staraniem i nakładem rządcy parafii księdza Maurycego Dziekońskiego. Stał on do 1818 roku, gdy na jego miejsce wystawiono kościół z cegły.

${ }^{402}$ SGKP, t. 9, s. 707. Stan, k. 11 zawiera informację o „przyczynieniu” kaplicy w Rokitnie przez biskupa Franciszka Ossolińskiego (a zatem w okresie 1774-1782).

${ }^{403}$ SGKP, t. 9, s. 705.

${ }^{404}$ Pałucki, Stan, k. 18; Rulikowski, Opis, s. 127.

${ }^{405}$ Rulikowski, Opis, s. 127. Nieco inną wersję zawiera SGKP, t. 9, s. 707, który podaje wiadomość o wystawieniu przez Borkowskiego własnym kosztem drewnianej kaplicy w 1818 roku. Później Braniccy mieli tu wznieść kościół Wniebowzięcia NMP.

${ }^{406}$ SGKP, t. 9, s. 707. Wiadomość nie zawiera daty. Wszystko wskazuje jednak na to, że dotyczy ona XIX wieku.

${ }^{407}$ Pałucki, Stan, k. 17.

${ }^{408}$ Defensa Biskupstwa, s. 135 (Bratyń); Pałucki, Stan, k. 16; Heleniusz [Iwanowski], Wspomnienia, s. 267, 297.

${ }^{409}$ Pałucki, Stan, k. 19. SGKP, t. 1, s. 348 podaje, że była to filia parafii Ostrohładowicze. Nie podaje jednak żadnych informacji kiedy stan taki miał miejsce. 


\section{ROZWÓJ SIECI KOŚCIELNEJ W OSTATNIM DWUDZIESTOLECIU XVIII WIEKU}

Tekla z Niemiryczów Niemiryczowa 9 III 1785 roku fundowała kościół i klasztor karmelitów trzewiczkowych w Toporyszczu. Zakonnicy otrzymali od fundatorki budynki gospodarcze, plac, ogrody i sumę 40 tysięcy złotych, zaś uposażenie zostało jeszcze powiększone zapisami innych osób. Klasztor wzniesiono z drewna, zaś kościół ukończono budować 12 IX 1789. W 1791 roku został poświęcony, a w 1793 roku stał się ośrodkiem nowej parafii w ramach dekanatu owruckiego ${ }^{410}$. W Toporyszczu istniał już wcześniej kościół katolicki, lecz było to jeszcze w pierwszej połowie XVII wieku. Miejscowość nabył w tym czasie od Jelca arianin Jerzy Niemirycz i ,zniósł” tutejszą świątynię ${ }^{411}$.

W 1787 roku Rafał Tarnowski wraz z żoną Urszulą z Ustrzyckich fundowali drewniany kościół parafialny pod wezwaniem Wniebowzięcia NMP w Wasylowie. Pierwszym proboszczem w nowej parafii był ksiądz Onyfry Bukowski, zaś jego następcą ksiądz Kwiatkowski ${ }^{412}$.

Bardzo długo nie odbudowywano kościoła w Machnówce. Kościół i klasztor bernardynów (którzy prowadzili jednocześnie parafię), fundowane w 1628 ro$\mathrm{ku}^{413}$, uległy zniszczeniu 20 lat później po zdobyciu miasta przez Kozaków Krzywonosa, a Machnówka na długie lata stała się pustką ${ }^{414}$. W 1700 roku wciąż była tu ,ppustynia”, a powolne zasiedlenie nastąpiło po $1712 \mathrm{roku}^{415}$. W latach 17461748 tutejszy kościół wciąż był zniszczony, a miejscowość wchodziła w skład parafii berdyczowskiej ${ }^{416}$. Taki stan przetrwał do schyłku XVIII wieku. Dopiero po przejęciu obszaru diecezji kijowskiej przez Rosję w 1793 roku nastapiły zmiany. 4 V 1794 roku wojewoda kijowski Prot Potocki fundował w Machnówce „świecki” kościół parafialny pod wezwaniem św. Jana Nepomucena. Na rzecz kościoła zapisał 3 włóki oraz 3,5 morgi ziemi, a także 1000 złotych annuaty. Suma jego legacji wynosiła 23600 złotych, a do tego dochodziła suma legacji Józefa Moszyńskiego, Marcina Komorowskiego, Jana Klityńskiego, Zofii Dąbrowskiej

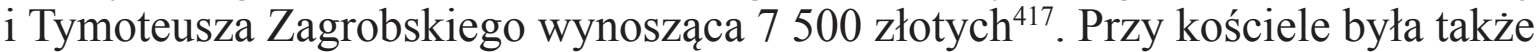
utrzymywana przez fundatora szkoła ${ }^{418}$. W 1795 roku biskup latyczowski (do-

${ }^{410}$ Wołyniak [Giżycki], Zniesione, s. 198-199; SGKP, t. 12, s. 402 datował powstanie parafii na 1799 rok. Nowy drewniany kościół pod wezwaniem św. Tekli wzniesiono tu ze składek w 1844 roku.

${ }^{411}$ SGKP, t. 7, s. 180.

${ }^{412}$ SGKP, t. 13, s. 142-143. W 1819 roku kościół był jeszcze nie konsekrowany. Proboszczem był ksiądz Wincenty Krupski, a parafia miała kaplice w Husaczówce i Kopaczowie. W 1845 roku ze składek parafian na miejscu drewnianego wzniesiono kościół murowany, który w 1850 roku został konsekrowany przez biskupa łucko-żytomierskiego Kacpra Borowskiego.

${ }^{413}$ SGKP, t. 5, s. 876; Heleniusz [Iwanowski], Wspomnienia, s. 267, 296, 331; Sobieraj, Fundatorzy, s. 182

${ }^{414}$ SGKP, t. 5, s. 876.

${ }^{415}$ SGKP, t. 5, s. 878.

${ }^{416}$ Defensa Biskupstwa, s. 139; Heleniusz [Iwanowski], Wspomnienia, s. 267, 269.

${ }^{417}$ SGKP, t. 5, s. 880.

${ }^{418}$ Mrozowska, Uniwersytet, s. 77. 
tychczasowy kamieniecki) Michał Roman Sierakowski wydzielił ponownie parafię Machnówka. Objęła ona, poza samym miastem, 30 wsi i 4 nowe osady ${ }^{419}$. Początkowo kościół parafialny mieścił się w murach zniszczonego kościoła bernardynów. Ponieważ były to ruiny i mury były niebezpieczne Prot Potocki urządził w nich magazyny ${ }^{420}$.

Dziedzice Jan Hański z żoną Zofią ze Skorupków fundowali w 1796 roku kościół parafialny w Pulinach. Akt fundacyjny przewidywał budowę drewnianej świątyni i domu dla proboszcza, którego mieli prezentować fundatorzy. Jednocześnie zapisano kwoty 1000 złotych dla proboszcza i 400 złotych dla wikarego. Kościół pod wezwaniem św. Jana Nepomucena został zbudowany i konsekrowany jeszcze w tym samym roku przez prałata Janowskiego ${ }^{421}$. Parafię pulińską wyodrębniono zapewne z obszaru parafii żytomierskiej, do której Puliny należały w latach $1746-1748^{422}$.

Zwraca uwagę fakt, że wchłonięcie olbrzymich obszarów Rzeczypospolitej wraz z liczną ludnością łacińską przez Rosję całkowicie zmieniło sytuację Kościoła łacińskiego w tym kraju. Po upadku Polski pozwolono nawet odbudować świątynię w samym Kijowie. Pierwszy metropolita i arcybiskup mohylowski Stanisław Bohusz Siestrzeńcewicz doprowadził do budowy drewnianego kościoła w tym mieście. Został on wzniesiony ze składek i w 1798 roku benedykowany pod wezwaniem Zwiastowania NMP przez archidiakona kijowskiego Stanisława Steckiego. Z racji braku środków na utrzymanie kapłana przy świątyni podjęto decyzję o sprowadzeniu dominikanów. Do Kijowa przybyła w 1801 roku połowa dominikanów z klasztoru w Czarnobylu, a uposażenie placówki kijowskiej stanowić miała połowa dotychczasowego uposażenia klasztoru czarnobylskiego ${ }^{423}$.

Zapewne krótko po 1782 roku powstały kaplice w Orlowcu i Zielonej Dąbrowie na terenie parafii Śmiła. Nie zostały odnotowane przez M. Pałuckiego, natomiast ich istnienie zostało potwierdzone w $1786 \mathrm{roku}^{424}$.

Jednym z ostatnich punktów sieci świątyń diecezji kijowskiej, który powstał przed końcem XVIII wieku była kaplica w Zlotopolu, zwanym do 1787 roku Hulajpolem ${ }^{425}$. W 1791 roku Anna Staal, żona Gustawa, pełnomocnika klucza turiańskiego dóbr hrabiego Potiemkina wystawiła w Złotopolu drewnianą kaplicę. Kaplica ta aż do 1795 roku pozostawała pod opieką franciszkanów, a następnie przeszła pod zarząd proboszcza śmilańskiego ${ }^{426}$.

${ }^{419}$ SGKP, t. 5, s. 879; Heleniusz [Iwanowski], Wspomnienia, s. 275.

${ }^{420}$ SGKP, t. 5, s. 880. Odbudowę kościoła bernardynów rozpoczęto dopiero w 1840 roku.

${ }^{421}$ SGKP, t. 9, s. 281, 284.

${ }^{422}$ Defensa Biskupstwa, s. 136; Heleniusz [Iwanowski], Wspomnienia, s. 268.

${ }^{423}$ Wołyniak [Giżycki], Zniesione, s. 179-180.

${ }^{424}$ SGKP, t. 10, s. 883. Co prawda Stownik zawiera datę 1768, ale jest to błąd literowy, co wynika z kolejności zapisu, a także z podanej gdzie indziej (t. 14, s. 599) wiadomości o „osadzenu” Zielonej Dąbrowy dopiero w 1780 roku. SGKP, t. 7, s. 591 podaje wiadomość o istnieniu kaplicy w Orłowcu, lecz bez odniesienia czasowego.

${ }^{425}$ SGKP, t. 14, s. 642.

${ }^{426}$ SGKP, t. 14, s. 643. W 1807 roku major Mikołaj Wysocki wydał dokument zezwalający na budowę murowanego kościoła, który jeszcze w tym samym roku uzyskał akt erekcyjny. Jednak 
Nie zdołała się odrodzić dawna parafia w Bystrzyku, która istniała przed powstaniem Chmielnickiego ${ }^{427}$. W latach 1746-1748 nie było tu świątyni łacińskiej i zapewne nie zdołano jej już odbudować ${ }^{428}$. Występująca w literaturze informacja o istnieniu w Bystrzyku murowanej kaplicy pozbawiona jest daty ${ }^{429}$ i może dotyczyć XIX wieku. Podobna sytuacja miała miejsce w Januszpolu. Istniejąca tu w pierwszej połowie XVII wieku parafia uległa zniszczeniu. W latach 1746-1748 nie było tu kościoła i nie odbudowano go już do końca istnienia Rzeczypospolitej ${ }^{430}$. Posiadamy informację o istnieniu w Januszpolu kaplicy filialnej, jednak są one pozbawione datacji, a ponadto rozbieżne $\mathrm{w}$ kwestii podległości parafial$n \mathrm{j}^{431}$.

Nigdy nie odnowiono parafii, która działała w pierwszej połowie XVII wieku w Korsuniu ${ }^{432}$. W latach 1746-1748 tutejszy kościół był jeszcze spustoszony i nie został już odbudowany do końca istnienia Rzeczypospolitej ${ }^{433}$. W 1784 roku istniała w Korsuniu kaplica, ale raczej unicka niż łacińska ${ }^{434}$. Dopiero w XIX wieku powstał tu katolicki „kościółek albo raczej kapliczka”435.

$\mathrm{Z}$ podobną sytuacją mamy do czynienia w przypadku Miropola. Przed powstaniem Chmielnickiego istniał tu kościół parafialny ${ }^{436}$, który potem uległ zniszczeniu. W latach 1746-1748 nie było tu kościoła, a Miropol należał do parafii cudnowskiej ${ }^{437}$. Co prawda posiadamy informację, że świątynia parafialna została tu odbudowana po $1748 \mathrm{roku}^{438}$, ale zapewne miało to miejsce dopiero w XIX wieku ${ }^{439}$.

Z pewnym prawdopodobieństwem możemy przyjąć powstanie u schyłku XVIII wieku kaplicy przy dworze nad Dnieprem w Czerkasach. W mieście tym

budowa kościoła przeciągnęła się i ostatecznie kościół Niepokalanego poczęcia NMP („Maryi Niepokalanego Poczęcia”) został fundowany dopiero w 1817 roku przez księdza Maurycego Dziekońskiego.

${ }^{427}$ Defensa Biskupstwa, s. 135; Stan, k. 15v; Heleniusz [Iwanowski], Wspomnienia, s. 266, 296.

${ }^{428}$ Heleniusz [Iwanowski], Wspomnienia, s. 266.

${ }^{429}$ Heleniusz [Iwanowski], Wspomnienia, s. 281.

${ }^{430}$ Januszpol w latach 1746-1748 należał do parafii cudnowskiej. Defensa Biskupstwa, s. 1138; Pałucki, Stan, k. 15v; Heleniusz [Iwanowski], Wspomnienia, s. 266, 296.

${ }^{431}$ Heleniusz [Iwanowski], Wspomnienia, s. 268 podaje, że kaplica należała do parafii cudnowskiej, natomiast SGKP, t. 3, s. 445, że do krasnopolskiej.

${ }^{432}$ Defensa Biskupstwa, s. 135; Stan, k. 15v; Heleniusz [Iwanowski], Wspomnienia, s. 267, 296.

${ }^{433}$ Heleniusz [Iwanowski], Wspomnienia, s. 267.

${ }^{434}$ SGKP, t. 5, s. 44.

${ }^{435}$ SGKP, t. 5, s. 45.

${ }^{436}$ Pałucki, Stan, k. 15v; Heleniusz [Iwanowski], Wspomnienia, s. 266, 296.

${ }^{437}$ Defensa Biskupstwa, s. 138; Heleniusz [Iwanowski], Wspomnienia, s. 266, 268 zalicza Miropol raz do parafii Cudnów, raz do parafii Lubar.

${ }^{438}$ Heleniusz [Iwanowski], Wspomnienia, s. 268.

${ }^{439}$ SGKP, t. 6, s. 496 podaje, że murowany kościół pod wezwaniem św. Antoniego Padewskiego został zbudowany przez dziedziców Rostworowskich w 1820 roku, a konsekrowany w 1828 ro$\mathrm{ku}$. 
próbowano założyć kościół i klasztor dominikanów jeszcze przed powstaniem Chmielnickiego, ale zamiar ten nie został zrealizowany ${ }^{440}$. W XVIII wieku istnienie kaplicy zostało potwierdzone w 1789 roku $^{441}$, ale także w tym przypadku nie ma pewności czy była to kaplica łacińska czy unicka. Posiadamy także wiadomość o czerkaskiej filii łacińskiej parafii Śmiła, lecz jest ona pozbawiona odniesienia czasowego ${ }^{442}$.

Podsumowując stwierdzamy, że na terenie diecezji kijowskiej już w drugiej połowie XVII wieku działało co najmniej 10-11 świątyń łacińskich (siedziba jednej z nich uległa w tym okresie zmianie). Po kolejnej fali zniszczeń, która dotknęła sieć kościelną na przełomie XVII i XVIII wieku, obserwujemy stosunkowo szybką jej odbudowę począwszy od lat dwudziestych XVIII wieku. Trudno jest ustalić dokładną liczbę świątyń funkcjonujących w tym czasie, ale pod koniec lat dwudziestych było ich już zapewne nie mniej niż 15, a być może nawet 20. Pod koniec lat czterdziestych liczba ta wzrosła do co najmniej 25, a dziesięć lat później na pewno przekroczyła 30. Walki, które wybuchły na Ukrainie w 1768 roku ponownie zahamowały rozwój sieci kościelnej w diecezji kijowskiej (co najmniej siedem świątyń zostało zniszczonych i przez pewien okres nie funkcjonowało), ale było to zjawisko przejściowe. Od lat siedemdziesiątych obserwujemy dalszy wzrost liczby świątyń łacińskich, których w 1782 roku było już blisko 50. Część z nich okazała się placówkami nietrwałymi, lecz jednocześnie powstawały nowe kościoły i kaplice. W efekcie na przełomie XVIII i XIX wieku na omawianym przez nas obszarze funkcjonowały 53 łacińskie świątynie. Istniały co najmniej 42 parafie, w tym 11 prowadzonych przez zakony.

Warto także zwrócić uwagę na fakt, że w omawianym przez nas okresie nastąpiły istotne zmiany dotyczące materiału, z którego były budowane świątynie. Nie wszystkie przekazy, którymi dysponujemy przynoszą wiadomości na ten temat. Tym niemniej posiadamy wystarczająco dużą liczbą wzmianek, aby zauważyć, że coraz częściej do budowy kościołów i kaplic używano trwałych materiałów. Powstawało coraz więcej świątyń murowanych. Trzy informacje, którymi dysponujemy, dotyczące materiału wykorzystywanego przy budowie kościołów w drugiej połowie XVII wieku mówią o wykorzystaniu drewna. Tymczasem już w pierwszej połowie następnego stulecia na 21 świątyń, dla których dysponujemy informacjami dotyczącymi materiału, z którego je wznoszono, 18 było drewnianych, zaś 3 murowane (co stanowiło 14,3\% ich ogólnej liczby). Omawiana tendencja nasiliła się jeszcze w drugiej połowie XVIII wieku. Spośród 41 świątyń wznoszonych w tym okresie murowanych było 10 kościołów $(24,4 \%)$, a dwa kolejne były drewniane, lecz rozpoczęto też budowę ich murów. Jeszcze jednak w 1767 roku Statua synodu diecezji kijowskiej zawierały wiadomość, że świątynie na Ukrainie są budowane prawie wyłącznie z drewna ${ }^{443}$. Należy podkreślić, że zasygnalizowane zjawisko wzrastającej liczby świątyń murowanych nie było wyjątkowe i ograniczone wyłącznie do diecezji kijowskiej. Duży odsetek murowanych kościołów

\footnotetext{
${ }^{440}$ SGKP, t. 1, s. 807.

${ }^{441}$ SGKP, t. 1, s. 808.

${ }^{442}$ SGKP, t. 1, s. 803 .

${ }^{443}$ Statua, s. [681].
} 
na terenach wschodnich Rzeczypospolitej około 1772 roku daje się zauważyć także na obszarach archidiecezji lwowskiej, diecezji kamienieckiej, oraz archidiakonatu łuckiego (na Wołyniu i Bracławszczyźnie), a zatem na terenach szczególnie zniszczonych w czasie wojen $\mathrm{z}$ drugiej połowy XVII wieku. Zapewne było to odbicie tendencji do odbudowy zniszczonych świątyń z materiałów bardziej trwałych, a przez to do stworzenia z kościołów miejsc potencjalnego schronienia ludności polskiej ${ }^{444}$.

${ }^{444}$ Litak, Parafie w Rzeczypospolitej w XVI-XVIII wieku. Struktura, funkcje społeczno-religijne $i$ edukacyjne, Lublin 2004, s. 90-92. 


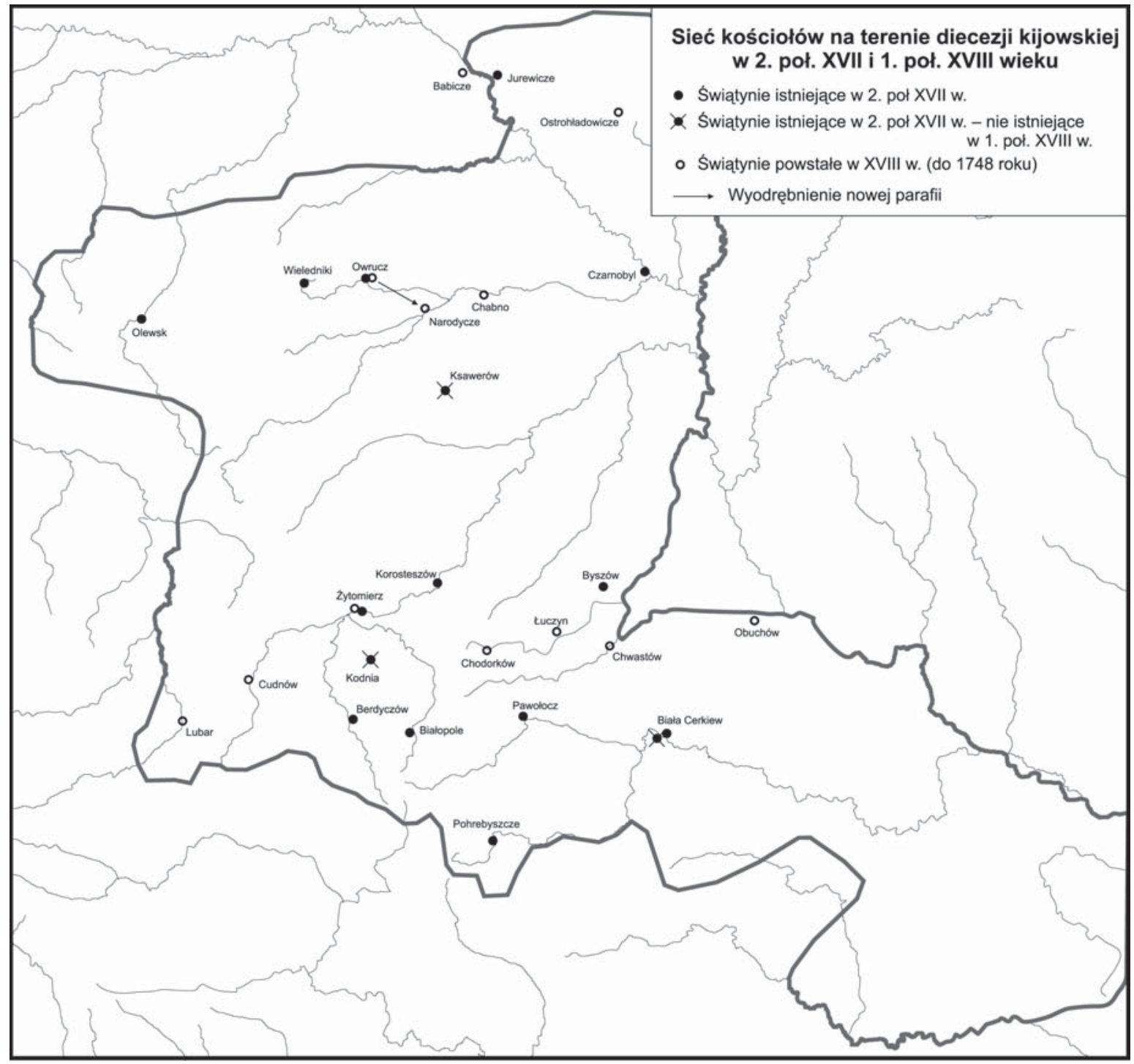

Mapę wykonał Mirosław Pieńkowski. 


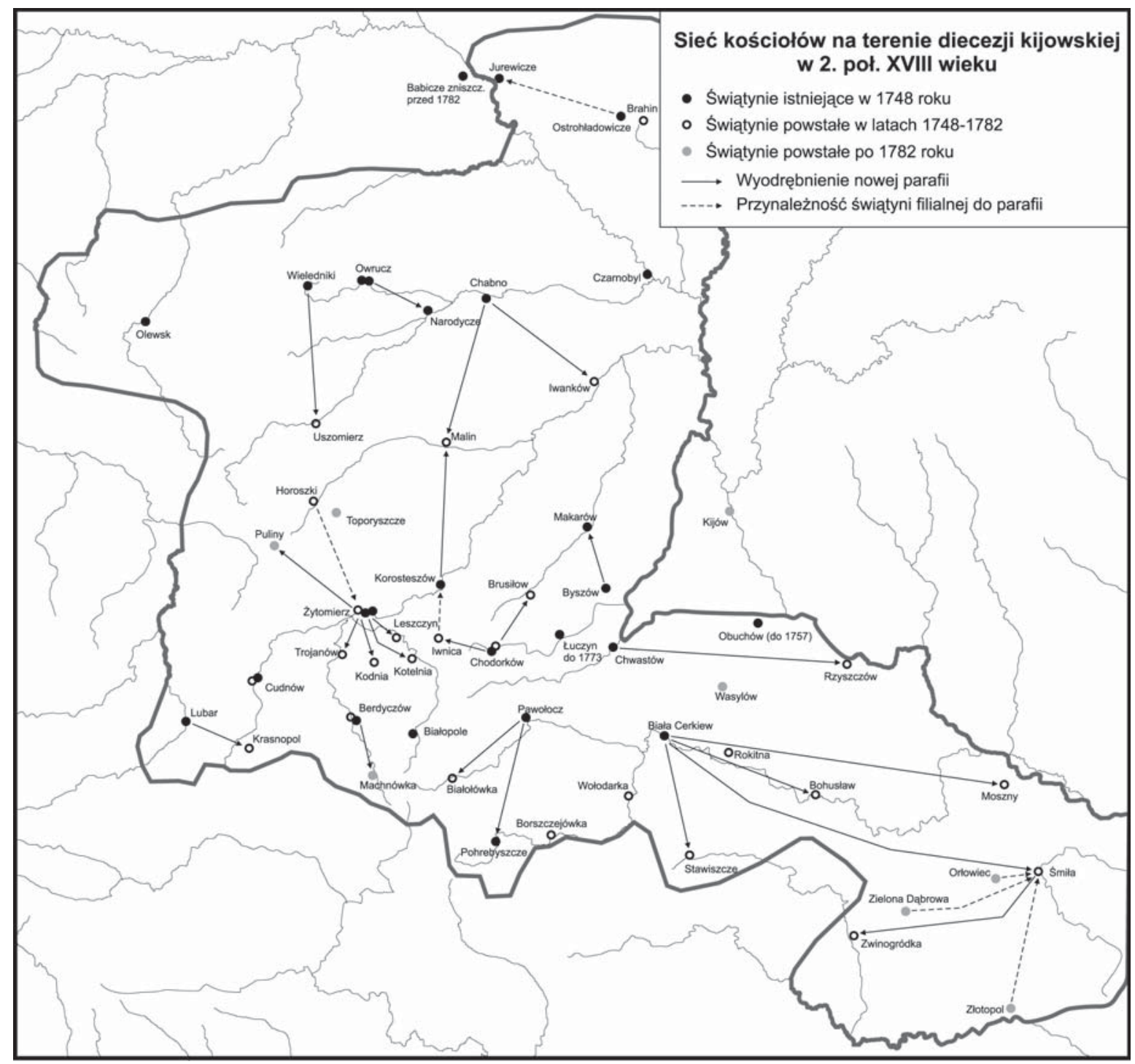

Mapę wykonał Mirosław Pieńkowski. 


\section{DER ZUSTAND UND DIE REKONSTRUKTION DES KIRCHLICHEN NETZES IN DER LATEINISCHEN DIÖZESE KIEW IN DER ZWEITEN HÄLFTE DES 17. UND IM 18. JAHRHUNDERT}

\section{Zusammenfassung}

Der Artikel behandelt die Entwicklung des Netzes katholischer Kirchen und öffentlicher Kapellen lateinischen Ritus' auf dem Gebiet der Diözese Kiew im Zeitraum von der Mitte des 17. bis zum Ende des 18. Jahrhunderts. Diese Problematik ist bisher nicht detailliert bearbeitet worden, und der vorliegende Beitrag soll die diesbezügliche Lücke in der Geschichtsschreibung wenigstens teilweise ausfüllen. Auf der Grundlage von Quellen aus dem 18. Jahrhundert (hauptsächlich der Beschreibung der Diözese Kiew durch Archidiakon Karol Ostrowski aus dem Jahre 1748, der Synodalstatuten der Diözese Kiew aus den sechziger Jahren des 18. Jahrhunderts sowie der im Jahre 1782 vom Generaloffizial Michał Pałucki verfassten, nur als Handschrift vorliegenden Zustandsbeschreibung der Diözese) sowie verstreuter Erwähnungen in der einschlägigen Literatur wurde der Versuch einer Rekonstruktion des Zustandes des kirchlichern Netzes auf dem Gebiet der Diözee Kiew in der zweiten Hälfte des 17. Jahrhunderts sowie des Prozesses ihres schrittweisen Ausbaus und ihrer Erweiterung im darauffolgenden Jahrhundert unternommen.

Im Ergebnis wurden Zahlen der auf dem genanten Territorium zu verschiedenen Zeitpunkten funktionierenden Kirchen ermittelt, die von den in der Literatur angetroffenen Angaben etwas abweichen. Es wurde festgestellt, dass am Ende der zwanziger Jahre des 18. Jahrhunderts mindestens 15 Kirchen in Betrieb waren (damals konnten das sogar 20 sein), um 1750 über 25, um 1760 über 30 und im Jahre 1782 fast 50 Kirchen. Letztendlich gab es um 1800 auf dem uns interessierenden Territorium 53 katholische Kirchen, von denen mindestens 42 Pfarrkirchen waren (11 dieser Pfarreien wurden von Orden geführt). 